San Jose State University

SJSU ScholarWorks

Master's Theses

Master's Theses and Graduate Research

1995

\title{
Congressional intent and the subsequent interpretation of Titles VI and VII of the 1964 Civil Rights Act
}

Martin C. Grilli

San Jose State University

Follow this and additional works at: https://scholarworks.sjsu.edu/etd_theses

\section{Recommended Citation}

Grilli, Martin C., "Congressional intent and the subsequent interpretation of Titles VI and VII of the 1964 Civil Rights Act" (1995). Master's Theses. 1143.

DOI: https://doi.org/10.31979/etd.6uab-rbs5

https://scholarworks.sjsu.edu/etd_theses/1143

This Thesis is brought to you for free and open access by the Master's Theses and Graduate Research at SJSU ScholarWorks. It has been accepted for inclusion in Master's Theses by an authorized administrator of SJSU ScholarWorks. For more information, please contact scholarworks@sjsu.edu. 


\section{INFORMATION TO USERS}

This manuscript has been reproduced from the microfilm master. UMI films the text directly from the original or copy submitted. Thus, some thesis and dissertation copies are in typewriter face, while others may be from any type of computer printer.

The quality of this reproduction is dependent upon the quality of the copy submitted. Broken or indistinct print, colored or poor quality illustrations and photographs, print bleedthrough, substandard margins, and improper alignment can adversely affect reproduction.

In the unlikely. event that the author did not send UMI a complete manuscript and there are missing pages, these will be noted. Also, if unauthorized copyright material had to be removed, a note will indicate the deletion.

Oversize materials (e.g., maps, drawings, charts) are reproduced by sectioning the original, beginning at the upper left-hand corner and contimuing from left to right in equal sections with small overlaps. Each original is also photographed in one exposure and is included in reduced form at the back of the book.

Photographs included in the original manuscript have been reproduced xerographically in this copy. Higher quality $6^{n} \times 9^{n}$ black and white photographic prints are available for any photographs or illustrations appearing in this copy for an additional charge. Contact UMI directly to order.

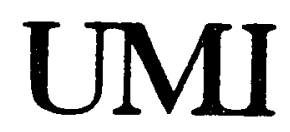

A Bell \& Howell information Cort:pany

300 North Zeeb Road. Ann Afbor. Mi 48106-1346 USA

$313 ! 761-4700 \quad 800: 521-0600$ 



\title{
CONGRESSIONAL INTENT AND THE \\ SUBSEQUENT INTERPRETATION OF TITLES \\ VI AND VII OF THE 1964 CIVIL RIGHTS ACT
}

\author{
A Thesis \\ Presented to \\ The Faculty of the Department of History \\ San Jose State University \\ In Partial Fulfillment \\ of the Requirements for the Degree \\ Master of Arts
}

by

Martin C. Grilli

December, 1995 
UMI Number: 1377234

UMI Microform 1377234

Copyright 1996, by UMI Company. All rights reserved.

This microform edition is protected against unauthorized copying under Title 17, United States Code.

\section{UMI}

300 North Zeeb Road

Ann Arbor, MI 48103 
- 1995

Martin Craig Grilli

ALL RIGHTS RESERVED 
APPROVED FOR THE DEPARTMENT OF HISTORY

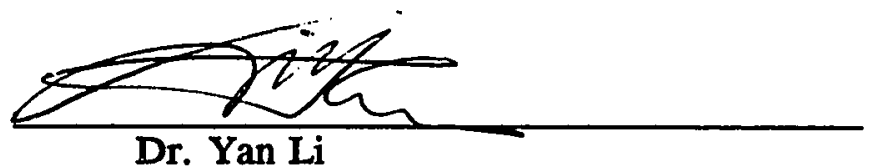

Dr. Man Li
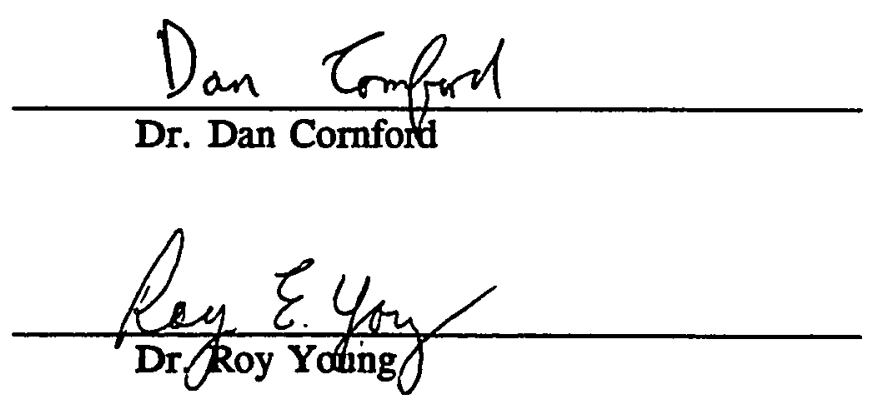

APPROVED FOR THE UNIVERSITY

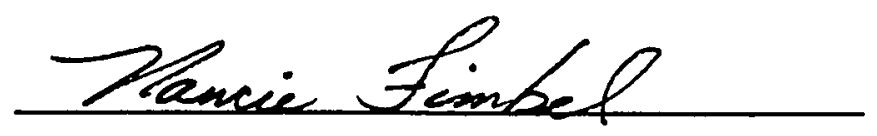




\title{
ABSTRACT \\ CONGRESSIONAL INTENT AND THE \\ SUBSEQUENT INTERPRETATION OF TITLES \\ VI AND VII OF THE 1964 CIVIL RIGHTS ACT
}

\author{
by Martin C. Grilli
}

From the beginning, the executive agencies charged with enforcing the Civil Rights Act of 1964 have felt constrained by the narrow definition of "discrimination" written into the Act by Congress. These agencies have subtly reinterpreted Titles VI and VII in such a manner that these Titles are now enforced in ways that Congress had not intended.

Research on this subject reveals that the federal judiciary has often shared the same view of Titles VI and VII as the executive agencies charged with its enforcement. In several major decisions, the judiciary has resorted to historical revisionism in order to aid these executive agencies in circumventing the explicit language of the Act. In the other cases, the judiciary simply ignored the historical record of the 88th Congress that wrote the Act, because such material would not support its attempt to rewrite the Act. As a result, Titles VI and VII of the 1964 Act have been badly distorted. 


\title{
TABLE OF CONTENTS
}

\begin{abstract}
$\ldots \ldots \ldots \ldots \ldots \ldots \ldots \ldots \ldots \ldots \ldots$ iv
Chapter

1. INTRODUCTION $\ldots \ldots \ldots \ldots \ldots \ldots \ldots \ldots$

2. THE PHILADELPHIA PLAN $\ldots \ldots \ldots \ldots \ldots \ldots$

Contractors' Association v. Shultz

311 F. Supp. 1002 (E.D. Pa. 1970) … . . . . . . 11

Contractors' Association v. Shultz

442 F.2d 159 (3d cir. 1971) . . . . . . . . . . 30
\end{abstract}

3. GRIGGS $\ldots \ldots \ldots \ldots \ldots \ldots \ldots \ldots \ldots \ldots$

Griggs v. Duke Power

292 F. Supp. 243 (M.D.N.C. 1968) _ . . . . . . . 37

Griggs v. Duke Power

420 F.2d 1225 (4th cir. 1970) . . . . . . . . . . . 44

Griggs v. Duke Power

401 U.S. 424 (1971) . . . . . . . . . . . . . . . . . 47

4. WEBER $\ldots \ldots \ldots \ldots \ldots \ldots \ldots \ldots \ldots \ldots$

Weber v. Kaiser Aluminum

415 F. Supp. 761 (E.D. La. 1976) . . . . . . . . . . 64

Weber v. Kaiser Aluminum

563 F.2d 216 (5th cir. 1977) . . . . . . . . . . . . 66

United Steelworkers $v$. Weber

443 U.S. 193 (1979) . . . . . . . . . . . . . . . . . . 70 
5. BAKKE $\ldots \ldots \ldots \ldots \ldots \ldots \ldots \ldots \ldots \ldots$

Bakke v. Regents of U.C.

18 Cal. 3d 34, 553 P. 2d 1152 (1976) . . . . . . . . 96

Regents of U.C. v. Bakke

438 U.S. 265 (1978) . . . . . . . . . . . . . . . . . . 101

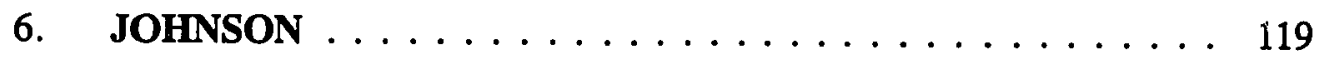

Johnson v. Transportation Agency

770 F.2d 752 (9th cir. 1984) . . . . . . . . . . . 120

Johnson v. Transportation Agency

480 U.S. 616 (1987) . . . . . . . . . . . . . . . . . 123

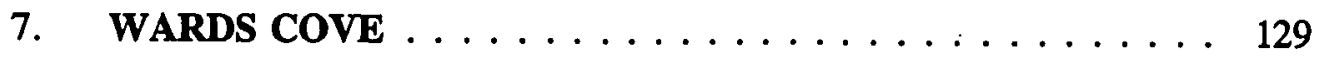

Wards Cove v. Antonio

490 U.S. 642 (1989) . . . . . . . . . . . . . . . . . 134

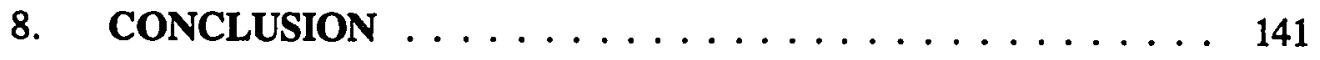

Appendix

SELECTED BIBLIOGRAPHY $\ldots \ldots \ldots \ldots \ldots \ldots \ldots \ldots .145$

A. Primary Sources . . . . . . . . . . . . . 145

B. Secondary Sources . . . . . . . . . . . . . . 146 


\section{CHAPTER 1 \\ INTRODUCTION}

Just before he died, famed abolitionist and Massachusetts Senator Charles

Sumner leaned over to Frederick Douglas and implored him not to let his Civil Rights Act fail. ${ }^{1}$ In 1875 , the Act would become law. It did not last long.

The Supreme Court, in the Civil Rights Cases, ${ }^{2}$ invalidated the Act as not authorized by the powers granted to Congress. The Court, through Justice Bradley, reasoned that since the Fourteenth Amendment only prohibits state action, it did not extend to acts by private citizens. As restaurants and theaters were not creations of the state, the federal government had no rightful authority over them. ${ }^{3}$ Justice John Marshall Harlan's legendary dissent notwithstanding, the Court invalidated the nation's first comprehensive Civil Rights Act. ${ }^{4}$ The nation would wait eighty-nine years for another comprehensive civil rights act.

It was not until 1964, some ten years after the Brown decision and one

${ }^{1}$ Charles Fairman, Reconstruction and Reunion 1864-88: Part Two, Oliver Wendell Holmes Devise: History of the Supreme Court of the United States, volume VII (New York: Macmillan, 1987), 175.

${ }^{2} 109$ U. S. 3 (1883).

${ }^{3}$ Alan Westin, "The Case of the Prejudiced Doorkeeper," in John Garrity, ed., Quarrels that have Shaped the Constitution (New York: Harper \& Row, 1987), 149.

${ }^{4}$ Fairman, Reconstruction and Reunion, 156-84. 
hundred years after the Emancipation Proclamation, that Congress passed another major civil rights act. Other acts had been passed, but had been so badly diluted by opponents as to make them virtually worthless. By 1964, proponents of civil rights laws were determined to add desegregation and public accommodations requirements, along with nondiscriminatory employment practices nationwide and federal authority to intervene in discrimination cases. The 1964 Act was a long time coming, but it did not pass without stubborn resistance.

Lyndon Johnson was determined to pass the Act, and suggested to the nation that such an act would be a fitting tribute to the fallen John F. Kennedy. ${ }^{5}$ Despite Johnson's position as President, many in his own party were unwilling to co-operate. Much as they had done before in defeating similar proposals, the southern block of the Democratic party conspired to literally talk the proposed 1964 Act out of existence. These Senators knew only too well the power of the filibuster. ${ }^{6}$

Over the course of several months, Congress debated the Civil Rights Act of 1964. Opponents of the bill spent hours on end analyzing every section of the Act, looking for any weaknesses. This tactic had worked in the past, but supporters of the Act were determined to succeed this time. Organizing themselves into teams to counter the efforts of the southern Democrats, supporters of the Act took it upon

${ }^{5}$ Robert Loevy, To End All Segregation: The Politics of the Passage of the Civil Rights Act of 1964 (Lanham, M.D.: University Press of America, 1990), 85.

${ }^{6}$ Loevy, To End All Segregation, 132-35. 
themselves to refute the allegations at every turn. ${ }^{7}$ And as critics of the Act began running out of things to say, they took to making the same accusations repeatedly. Supporters, in turn, mounted one defense after another in favor of the Act. The legislative history of the Act, as recorded in the Congressional Record, totalled thousands of pages.

After one of the most protracted debates in the entire history of the Congress, the Senate took the extraordinary step of invoking cloture and suspending unlimited debate. This was no small feat, as many senators were skeptical about suspending debate, even if such a thing were necessary to pass a civil rights act. ${ }^{8}$ Once the filibuster had been broken, the Act was quickly passed and sent to Johnson, who promptly signed it. The Civil Rights Act of 1964 was law.

The Civil Rights Act of 1964 has been the source of extraordinary amounts of litigation. Any major act of Congress generates litigation, but this particular Act was different. From the beginning, the Justice Department, the NAACP and other groups have used litigation in an attempt to stretch the 1964 Act to its maximum potential. The precise meaning of this Act has been the source of considerable debate.

The purpose of this thesis is to study the path which the federal judiciary has

${ }^{7}$ Loevy, To End all Segregation, 129-51.

${ }^{8}$ Barbara and Charles Whalen, The Longest Debate: A Legislative History of the 1964 Civil Rights Act (Cabin John, M.D.: Seven Locks Press, 1985), 270-74; Loevy, To End All Segregation, 281-86. 
taken in interpreting Titles VI and VII of the Civil Rights Act of 1964. In particular, this thesis focuses particular attention on how the court has used the voluminous legislative history of the Act, as recorded in the Congressional Record. As the thesis will argue, the federal judiciary has used the legislative history of Titles VI and VII to reach some highly peculiar results.

As critics of the Act attacked one provision after the other, supporters were under constant pressure to give the Act greater clarity and precision. Critics insisted that much as previous acts of Congress had been subtly rewritten by the executive bureaucracy, this Act would be reinterpreted and enforced in ways that Congress explicitly did not want. In order to rebuke such criticism, the bill that was finally passed was written with exceptionally clear language, and left little room for ambiguity or conflicting interpretation. ${ }^{9}$ Supporters repeatedly stressed that the executive branch could not seize upon any ambiguities in order to distort the true meaning of the Act. ${ }^{10}$

Professor Hugh Graham, in his superb book The Civil Rights Era: Origins and Development of National Policy, 1960-1972, has demonstrated that from the beginning, the executive agencies charged with enforcing Titles VI and VII have felt constrained by the narrow definition of "discrimination" as set forth by Congress.

${ }^{9}$ Francis Vaas, "Title VII: Legislative History," Boston College Industrial and Commercial Law Review 7 (1966): 444.

${ }^{10}$ Andrew Kull, The Color-Blind Constitution (Cambridge: Harvard University Press, 1992), 182-83. 
Many within the Equal Employment Opportunity Commission (EEOC), the NAACP, and the Office of Federal Contract Compliance (OFCC) felt that Congress' solution to racial discrimination in employment was inadequate to the task. They quickly concluded that the very Act designed to eradicate discrimination was an obstacle to be overcome in an attempt to eradicate discrimination. ${ }^{11}$

As the caseload for Title VI and Title VIl cases began to grow exponentially, agencies like the OFCC and EEOC began to argue that the case-by-case approach mandated by Congress was increasingly unworkable. Instead of finding intentional discrimination, these agencies came to believe that numerical equality, in the form of goals, timetables, and quotas, would be far more effective in enforcing nondiscrimination compliance. Even further, these agencies felt that the failure of the 1964 Act to produce immediate results was proof of its inadequacy. A new definition of discrimination, incorporating racial balance and ignoring proof of intent, was soon adopted. ${ }^{12}$ The explicit wording of the Act was seen as a hinderance to its true purpose of eliminating discrimination.

As this thesis will argue, the explicit wording of the Act foreclosed the possibility of misinterpretation. Instead, the explicit language of the Act was downplayed by the federal bureaucracy and other groups, and an attempt was made to

${ }^{1}$ Hugh Graham, The Civil Rights Era: Origins and Development of National Policy (New York: Oxford University Press, 1990), passim.

${ }^{12}$ See Graham, The Civil Rights Era, at 233-54; Kull, The Color-Blind Constitution, at 200-10. 
redefine the debate over Titles VI and VII based upon their legislative and historical records. For example, as will be revealed in the discussions of Griggs, Weber, and the Philadelphia Plan, the EEOC tried to create an ambiguity in the Act, and then rely upon its own reading of the historical record in order to resolve the ambiguity in their favor.

This thesis does not, however, focus solely upon the executive bureaucracy and its attempt to rewrite the Act. Rather, it is an attempt to study how the legislative history of the Act, as recorded in the Congressional Record, has been both used and abused by the federal bureaucracy and the federal judiciary. As the discussions in the following chapters will argue, the federal judiciary often shared the same view of Titles VI and VII as the executive branch charged with its enforcement. But as the judiciary was also constrained by the explicit language of the Act, the judiciary was often willing to accept or create historical revisionism that allowed an escape from textual analysis. The end result was of dubious legitimacy.

Historical studies of judicial interpretation typically skim through all decisions of the Supreme Court regarding the subject, and conclude with the author discussing and predicting various trends. This thesis is an attempt to do something different. Instead of canvassing every decision interpreting Titles VI and VII, this thesis will focus on the most important decisions regarding these titles.

Law does not remain static, but rather evolves through a continuum. During 
this evolution, the law often takes many sharp twists and turns. These turns are known as landmark decisions; they define the direction in which the law will proceed. In between these decisions, the judiciary does little more than apply the rules set forth in the previous major decision, while simultaneously finding the ambiguities that force the next major confrontation. ${ }^{13}$ Effective legal history is the history of landmark decisions, and my thesis will attempt to follow this model.

This thesis focuses on what are six of the most important decisions interpreting Titles VI and VII of the Civil Rights Act of 1964. In each case study, an attempt has been made to trace the decision back to the court of original jurisdiction, and then to analyze each decision as it wound its way through the judiciary. Further, the original briefs and transcripts have been studied whenever such materials were available, along with the Congressional Record. This accumulation of all available material will enable the reader to develop a greater appreciation of the complexities that culminated in each landmark decision. Ultimately, this study of the judiciary's past decisions will allow the reader will develop a greater understanding of the law's present direction.

${ }^{13}$ For the seminal explanation of this theory see Benjamin Cardozo, The Nature of the Judicial Process (New Haven: Yale, 1921); see also Thomas Kuhn, The Structure of Scientific Revolutions (Chicago: University of Chicago, 1962). 


\section{CHAPTER 2}

\section{THE PHLADELPHIA PLAN}

When studying the intent and aftermath of the Civil Rights Act of 1964, nothing stands out quite as sharply as the "Philadelphia Plan." The history of this plan and its analysis in the courts provides perhaps the very best example of how the Civil Rights Act of 1964 has been interpreted.

Lyndon Johnson's popularity crumbled during the late 1960s, and he chose not to seek re-election in 1968 . Nonetheless, Johnson had spent years actively courting the black vote, and was determined to keep his promise to improve the lot of black Americans. In keeping this promise, he soon turned to affirmative action. ${ }^{14}$

"Affirmative action" was not a new concept. During passage of the Civil Rights Act of 1964, Congress was fully aware of Executive Order 10,925, issued by President Kennedy, which states that:

In connection with the performance of work under this contract, the contractor agrees as follows:

(1) The contractor will not discriminate against any employee or applicant because of race, creed, or national origin. The contractor will take affirmative action to ensure applicants are employed, and that employees are treated during employment without regard to their race, color, or national origin. ${ }^{15}$

\footnotetext{
${ }^{14}$ Graham, The Civil Rights Era, 233-54.

${ }^{15} 26$ Federal Register 1977 (1961) (emphasis added).
} 
The meaning of this requirement, as made explicit from its text, is that employers must be certain not to use race, color, or national origin in their employment practices. As one critic of affirmative action has pointed out, "the requirements of 10925 (only) require the contractor to be actively color-blind. ${ }^{16}$

The Civil Rights Act was passed in the summer of 1964. In September 1965, Lyndon Johnson issued his own executive order regarding enforcement of the Act. In doing so, many have argued that Johnson expanded the concept of affirmative action. The Order begins thus:

Part I-Section 101: It is the policy of the Government of the United States to provide equal opportunity in Federal employment for all qualified persons, to prohibit discrimination in employment because of race, creed, color, or national origin, and to promote the full realization of equal employment opportunity through a positive, continuing program in each executive department and agency. The policy of equal opportunity applies to every aspect of Federal employment policy and practice. ${ }^{17}$

Furthermore, Section 203(a) mandates the rejection of contractors' bids that do not include "Compliance Reports" regarding employment programs and statistics.

What is striking about E.O. 11,246 is its ambiguity. It speaks of a "positive, continuing program," and yet it also includes the nondiscrimination clause from E.O. 10,925 verbatim. The editors of the New York University Law Review explain the ambiguity well:

${ }^{16}$ Howard Sherain, "The Questionable Legality of Affirmative Action," Journal of Urban Law 51 (1973): 31 (emphasis in original).

${ }^{17}$ Executive Order 11,246, 30 Federal Register 12,319 (1965). 
The meaning of "affirmative action" to those who coined the term is thus strictly a matter of conjecture. . . . Superimposed on this historical context, "affirmative action" might have meant only that the employer was required to perform a "policing function" to ensure against any discrimination in his company. Such a limited interpretation of the phrase finds support in the language of the executive order. The "affirmative action" required by the order is that necessary to "ensure" treatment "without regard" to race or religion; to guarantee, in other words, that the company's employment practices are colorblind.

Affirmative action has been interpreted by the OFCC, however, to mean action not only to ensure present nondiscrimination but also to correct the results of past discrimination, and to develop programs which broaden minority group participation in the contractor's operation. ${ }^{18}$

The OFCC was quick to implement its new concept of affirmative action.

Beginning in 1965, the OFCC began to vigorously apply its version of E.O. 11,246 to the construction unions nationwide. This would culminate in the Revised Philadelphia Plan of $1969 .{ }^{19}$

The Philadelphia Plan, in its simplest terms, was based on the argument of proportionality. That is, minorities should be distributed in all jobs in numbers proportional to their presence in the available local work force. ${ }^{20}$ Since minorities were clearly underrepresented in the construction unions of Philadelphia, the conclusion drawn by the OFCC was that they were the victims of discrimination. And as any act of discrimination requires a discriminator, the Philadelphia Plan

\footnotetext{
${ }^{18}$ Note, "Executive Order 11246: Anti-Discrimination Obligations in Government Contracts," New York University Law Review 44 (1969): 593.

${ }^{19}$ Graham, The Civil Rights Era, at 233-54, 278-300, 322-45.

${ }^{20}$ Graham, The Civil Rights Era, 327.
} 
implied that somebody was guilty of discriminatory practices.

The Contractors Association of Eastern Pennsylvania, which was an association of major contractor firms from the Philadelphia area, challenged the Plan in court. The resulting decision produced the first landmark reading of key sections from the 1964 Civil Rights Act, which is where we now turn.

\section{Contractors' Association v. Shultz ${ }^{21}$}

If blacks had been discriminated against, the OFCC would not have needed to impose its goals and timetables. The heart of Title VII is its reference to employment practices:

It shall be an unlawful employment practice for an employer-

(1) to fail or refuse to hire or to discharge any individual, or otherwise to discriminate against any individual with respect to his compensation, terms, conditions, or privileges of employment, because of such individual's race, color, religion, sex, or national origin; or

(2) to limit, segregate, or classify his employees in any way which would deprive or tend to deprive any individual of employment opportunities or otherwise adversely affect his status as an employee, because of such individual's race, color, religion, sex, or national origin. ${ }^{22}$

In the event of a proven case of intentional discrimination, the Act grants

${ }^{21}$ The Contractors' Association of Eastern Pennsylvania v. George Shultz, U.S. Secretary of Labor, 311 F. Supp. 1002 (E.D. Pa. 1970).

${ }^{22}$ United States Code. Title 42, section 2000e-2(a); Many writers still use the original numerical designations from the Act. For the sake of expediency, I shall do so as well. This section was originally designated 703(a).

Another key provision, nearly identical to this one, prohibits discriminatory practices by unions; see United States Code 42: 2000e-2(c). 
broad remedial powers to the federal courts as well:

If the court finds that the respondent has intentionally engaged in or is intentionally engaging in an unlawful employment practice charged in the complaint, the court may enjoin the respondent from engaging in such unlawful employment practice, and order such affirmative action as may be appropriate, which may include reinstatement or hiring of employees, with or without back pay (payable by the employer, employment agency, or labor organization, as the case may be, responsible for the unlawful employment practice). . . . No order of the court shall require the admission or reinstatement of an individual as a member of a union or the hiring, reinstatement, or promotion of an individual as an employee, or the payment to him of any back pay, if such individual was refused admission, suspended, or expelled or was refused employment or advancement or was suspended or discharged for any reason other than discrimination on account of race, color, religion, sex or national origin. . . . ${ }^{23}$

If the court had found that blacks had in fact been victims of discrimination, then "affirmative action" as it is commonly understood would be entirely legal. Since the court is given broad leeway to fashion a remedy, including the authority to reinstate employees to the position where they would rightfully belong in the absence of an illegal practice, then a remedy instructing an employer to prefer the black victim over white employees for the next available vacancy would be entirely conceivable. ${ }^{24}$ Unfortunately, that was not the issue at hand in Philadelphia.

Lyndon Johnson's OFCC tried in 1968 to require contractors to include "goals

${ }^{23}$ United States Code 42: $2000 \mathrm{e}-5(\mathrm{~g})$; this section is also commonly referred to as 706(g).

${ }^{24}$ This broad interpretation of remedial authority would be confirmed by later events; see Note, "Civil Rights-Employment Discrimination-Preferential Minority Treatment as an Appropriate Remedy Under Section 703(j) of Title VII," Tennessee Law Review 42 (1975): 397- . 
and timetables" regarding minority employment on federal construction sites. The attempt was a failure, and the requirement was quickly rescinded. ${ }^{25}$ Only days later, however, Richard Nixon was elected President, and the effort to impose goals and timetables began anew. This was an ironic twist, as Nixon's denunciation of busing had been interpreted by many to include by implication a rejection of compensatory or preferential treatment for blacks. Even so, Nixon pressed ahead.

In the spring of 1969, the Labor Department issued its new guidelines for federal construction contractors. They required "good faith efforts" for minority employee utilization goals by the contractors. ${ }^{26}$ These were quickly challenged in the federal courts by the local contractors' association. The federal courts upheld the Plan.

Lyndon Johnson's OFCC director had tried to force federal contractors in Cleveland to guarantee sufficient minority group representation throughout all phases of the contract. ${ }^{27}$ This, however, flew in the face of exactly what Congress had decreed in 1964:

Nothing contained in this subchapter shall be interpreted to require any employer, employment agency, labor organization, or joint labor-management committee subject to this subchapter to grant preferential treatment to any individual or to any group because of the race, color, religion, sex, or national

${ }^{25}$ Graham, The Civil Rights Era, 278-97.

${ }^{26}$ James E. Jones, Jr., "The Bugaboo of Employment Quotas," Wisconsin Law Review (1970): 365.

${ }^{27}$ Graham, The Civil Rights Era, 286. 
origin of such individual or group on account of an imbalance which may exist with respect to the total number or percentage of persons of any race, color, religion, sex, or national origin employed by any employer, referred or classified by any labor organization, or admitted to, or employed in, any apprenticeship or other training program, in comparison with the total number of percentage of persons of such race, color, religion, sex, or national origin in any community, State, section, or other area, or in the available work force in any community, State, section, or other area. ${ }^{28}$

It was apparent that Nixon's Labor Department had the same intention as Johnson's, but they could not afford to make the same mistake that Johnson's EEOC and OFCC had made. After several abortive attempts at minimal hiring requirements, Nixon's OFCC turned to Philadelphia.

The new Revised Philadelphia Plan did not specifically require federal contractors to hire minorities. Rather, the vague requirement of "goals and timetables" was created, which was designed to circumvent the anti-quota wording of section 703(j). ${ }^{29}$ More importantly, the Revised Philadelphia Plan was predicated on a "finding" of discrimination. This would circumvent section 703(j) completely, so that the Plan could be cast as remedial. But as one critic acidly noted, "the Department of Labor decreed discrimination first and found it later." ${ }^{30}$ As Professor Graham points out, the Plan was announced first, then hearings necessary to find

${ }^{28}$ United States Code 42: 2000e-2(j) (emphasis added); this section is also referred to as $703(\mathrm{j})$.

${ }^{29}$ Graham, The Civil Rights Era, 326.

${ }^{30}$ Robert Schwerk, "The Philadelphia Plan: A Study in the Dynamics of Executive Power," Chicago Law Review 39 (1972): 741 (n. 100). 
discriminatory practices were hastily conducted. ${ }^{31}$ That is, the Plan was announced as a remedy for discrimination, even though no such thing had been proved or charges filed. Even those who fought the hardest for the Plan conceded that it was, "in effect, a quota system. ${ }^{132}$ This created a situation unique in the law, whereby a remedy is decreed before an injury is found.

What is striking about the federal district court opinion upholding the Plan is that the court accepted the "findings" of this "hearing" at face value. Judge Weiner accepted the Labor Department's assertion that the unions were discriminating against blacks, and that requiring contractors to actively pursue black employees would be an acceptable remedy. This "finding" was predicated purely upon one statistic: minority representation in the targeted unions was approximately 1 percent in a city that was approximately 30 percent black. ${ }^{33}$ The court was satisfied that this numerical disparity satisfied the requirement that there must be an active intent to discriminate.

Normally, a federal district court opinion contains several pages of "statements of facts" which are used by the federal appellate courts. These statements help explain the factual basis for the decision. In this case, there was no statement of facts, and the evidence was confined solely to the one numerical discrepancy. Neither

\footnotetext{
${ }^{31}$ Graham, The Civil Rights Era, 334, 341; The district court's opinion noted, without commenting on its significance, that the Plan was issued on June 27, 1969, while the hearings were conducted on August 26-28, 1969; 311 F. Supp. at 1005.

${ }^{32}$ Urban Coalition delegate, as cited in Graham, The Civil Rights Era, at 330.

${ }^{33} 311$ F. Supp. at 1005.
} 
the Labor Department nor the OFCC produced the name of any single individual who was found to have been the victim of discrimination.

The district court did not attempt to ascertain any legislative history or intent of the 88th Congress that wrote the 1964 Act. It was wise that the court did not, for then the court would have realized that Congress had already anticipated and rejected programs like the Revised Philadelphia Plan that had been predicated on "findings" of discrimination based on numerical disparities. ${ }^{34}$ Opponents of the Act repeatedly suggested that the Act would be distorted into something akin to the Revised Philadelphia Plan. These critics argued that the executive agencies (like the OFCC and EEOC) would change the definition of "discrimination" by eliminating the active intent requirement and resorting to findings of prima facie cases of discrimination based on racial imbalances. ${ }^{35}$

At the very beginning of the debates regarding the Act, Attorney General Robert Kennedy was called to appear before the Senate committee on the Judiciary. Senator Sam Ervin quickly confronted Kennedy with a Housing and Home Finance Agency regulation that would seem to have predated the Revised Philadelphia Plan by some six years:

Special conditions, page 6213 , discrimination. For the purpose of determining whether there has been discrimination in regard to Negro labor in violation of

${ }^{34}$ Schwerk, "The Philadelphia Plan," 753.

${ }^{35}$ Note, "Business Necessity Under Title VII of the Civil Rights Act of 1964: A No-Alternative Approach," Yale Law Journal 84 (1974): 103. 
the provision contained in the general conditions, titled "Qualifications for Employment," it is hereby provided that if the contractor pays to the Negro skilled labor at least 20 percent of the total amount paid in any period of 4 weeks for all skilled labor under the contract (irrespective of individual trades) and pays Negro unskilled labor at least 79 percent of the total amount paid in any period of 4 weeks for all unskilled labor under the contract, it shall be considered as prima facie evidence that the contractor has not discriminated against Negro labor. ${ }^{36}$

As Senator Ervin was quick to explain, if these numerical quotas were not met, this would be "prima facie evidence" that the contractor had, in fact, discriminated against blacks. The requirement of intent was eliminated. One opponent after another seized this argument. It was first raised in the House of Representatives by Congressman Rivers:

Let us assume that two women apply for the same job and both of them are equally eligible, one a white woman and one a Negro woman. . . . If he does not employ that colored woman and make that record, that employer will say, "Well, now, if I hire the colored woman I will not be in any trouble, but if I do not hire the colored woman and hire the white woman, then the Commission is going to be looking down my throat and will want to know why I did not. I may be in a lawsuit."

it. $^{37}$

This will happen as surely as we are here this afternoon. You all know

Members of the Senate were also quick to make the same argument. Many stressed that race would be a critical factor whenever an employment decision would need to be made. For example, Senator McClellan argued that,

\footnotetext{
${ }^{36}$ Congress, Senate, Committee on the Judiciary, Civil Rights-The President's Program, 1963, 88th Congress, 1st Session, 11 September 1963, 415.

${ }^{37}$ Congress, House of Representatives, 88th Congress, 2nd session Congressional Record (8 February 1964), volume 110, 2583.
} 
The way the title to which the Senator has referred is intended to operate, if a half dozen men were to apply for a job and one were colored, the businessman would have to make a showing with respect to all of the applicants. He would have the burden of establishing that he chose one of the five white applicants rather than the Negro because of some reason that would absolve him from alleged guilt of discriminating against the colored person. ${ }^{38}$

Senator Poff, in offering his observations of the Act, stressed his concern about racial balancing the use of inequalities as grounds for dragging an employer into court:

In searching out evidence of "inequality" or "discrimination" in employment practices, what will the Commission find to be "reasonable cause?" If the Negro labor force in a particular community constitutes 10 percent of the total labor force, will a company whose Negro employees constitute only 5 percent of the company payroll be considered guilty of discrimination?. . . .

At the "trial," the Commission presents whatever evidence it has compiled concerning racial disparity. At that point, the employers who has been charged with committing an "unlawful employment practice" must assume the burden of producing evidence to show . . . that he did not intend by such conduct to discriminate against the complainant on account of his race. $^{39}$

Senator Tower, in particular, was outspoken about the possibility of a Revised Philadelphia Plan. In a lengthy speech attacking the Act, Senator Tower insisted that the Act was designed to force proportionality and race-conscious hiring. Further, Tower felt that the EEOC and OFCC would quickly seize upon racial imbalances as an expedient way to find discrimination without proving intent as required by section

${ }^{38}$ Congress, Senate, 88th Congress, 2nd session Congressional Record (13 April 1964) 110: 7771; see also Congressional Record (21 March 1964) 110: 5877 (remarks of Senator Byrd).

${ }^{39}$ Congressional Record (8 February 1964) 110: 2576. 
703(c). Senator Tower felt that this would invert the meaning of "discrimination" as defined by Congress:

If a law prohibited employers from discriminating against men and women with red hair, the inevitable effects would be to give red-haired persons a preferred status and to assure them of an unequally good opportunity to be employed and promoted, because, by favoring them, their employer would avoid any charge of discriminating against them. In like manner, this antidiscrimination title actually would compel discrimination against minority groups, in favor of minority status.

There we open up a whole Pandora's box of possibilities. The only conceivable way the bill could be equitably administered would be to go into communities and say to each administrator . . . "You must hire so many Negroes, you must hire so many people of Mexican origin, (etc.)"40

This, however, was only one day's worth of Senator Tower's vituperation.

Several days later, he took up the charge again:

The bill is supposed to outlaw discrimination, but it does not define "discrimination". . . . No doubt there would be liberalized interpretations by the Commission, to the extent that this provision, would include or cover almost anything; and in time this all-powerful, omnipotent Commission of five members could determine when anyone had been discriminated against for any reason, and then it would "lower the boom" on the alleged offending employer. ${ }^{41}$

Not surprisingly, it was none other than Senator Tower who introduced section 703(j), in an attempt to preclude such a possible interpretation of the Act. The Act's supporters, however, insisted that $703(j)$ was unnecessary, and repeatedly replied to Tower's charges:

${ }^{40}$ Congressional Record (13 April 1964) 110: 7779-80; see also pages 7774-78.

${ }^{41}$ Congressional Record (24 April 1964) 110: 9026; see also Senator Tower's remarks at page 9034. 
Senator Eastland: Senators may read the 11 titles of the bill . . . and they will not find any definition of "discrimination". . . . Each Federal department or agency is given carte blanche to define these words as it may determine be "rule, regulation or order." Federal political appointees will invent their own definitions and make their own rules. They will devise their own penalties . .

Senator Humphrey: The reason I asked for a discussion is that there is no foundation for saying that the word "discrimination" has no precise, legal meaning. The eminent retired Supreme Court Justice, Mr. Charles A. Whittaker . . . observes:

The meaning of the term "discrimination," in its legal sense, is not different from its dictionary meaning.

Webster's New International Dictionary defines discrimination as:

A distinction, as in treatment; esp., an unfair or injurious distinction.

The Senator (Eastland) knows that the word "discrimination" has been used in many a court case. What it really means in the bill is a distinction in treatment. It means a distinction in treatment given to different individuals because of their different race, religion, or national origin. . . .

The answer to this question is that if race is not a factor, we do not have to worry about discrimination because of race . . . the word "discrimination" is simply defined. It means "different treatment." That is all it means. ${ }^{42}$

This, however, was not the only time Senator Humphrey challenged the critics directly. Some time later in the debates, he challenged Senator Robertson in one of the most interesting exchanges of the entire debate:

Humphrey: But I feel sure that the Senator from Virginia is not going to

${ }^{42}$ Congressional Record (21 March 1964) 110: 5863-64. One critic of affirmative action has suggested "that the senators' faith in the self-evidence of the term was somewhat naive." See Michael Brody, "Congress, the President, and Federal Equal Employment Policymaking: A Problem in Separation of Powers," Boston University Law Review 60 (1980): 242 (n. 5). 
suggest or intimate that under this title of the bill there would be such a thing as a quota or a required percentage.

Robertson: Not only am I going to intimate it, I am going to charge it; and I am also going to point it out in detail. . . .

Humphrey: Can the Senator point out any place in the language of the bill that calls for quotas or a percentage of employees based upon race, creed, color, or national origin? ... The Senator is a man of logic and reason. I ask him a simple question .... what about percentages and quotas?

Robertson: The bill has been framed by some very clever lawyers. They were so clever that they even fooled my distinguished friend from Minnesota. . . .

Humphrey: ... I would like to make an offer to him. If the Senator can find in title VII . . . any language which provides that an employer will have to hire on the basis of percentage or quota related to color, race, religion, or national origin, I will start eating the pages one after another, because it is not in there. ${ }^{43}$

During the lengthy debate over this Act, supporters published a "Bipartisan

Civil Rights Newsletter." The authors of this newsletter quickly reinforced

Humphrey's argument, and he promptly included it in the Congressional Record:

Defining discrimination: Critics of the civil rights bill have charged that the word "discrimination" is left undefined in the bill and therefore the door is open for interpretation of this term according to "whim or caprice." There is no mystery or vagueness about the word "discrimination" as it is used in the bill. . . . It means a distinction in treatment given to different individuals

${ }^{43}$ Congressional Record 9 April 1964) 110: 7418-20 (emphasis added). It is worth noting that Senator Humphrey promised that both quotas and requirements regarding employers to "hire on the basis of percentage" could not be found in the Act. This would seem quite clearly to reject the quotas/goals distinction relied upon by the federal courts in this case to circumvent the express prohibition of $703(\mathrm{j})$. 
because of their different race, religion, or national origin. ${ }^{44}$

In his lengthy address on the Senate floor encouraging his Senators to vote for this bill, Humphrey again addressed the critics and insisted that race would not be injected into the hiring process:

The only standard which the bill establishes for unions and management alike is that race will not be used as a basis for discriminatory treatment. . . . The truth is that this title forbids discriminating against anyone on account of race. This is the simple and complete truth about title VII. . . . Contrary to the allegations of some opponents of this title, there is nothing in it that will give any power to the Commission or to any court to require hiring, firing, or promotion of employees in order to meet a racial "quota" or to achieve a certain racial balance.

That bugaboo has been brought up a dozen times; but it is nonexistent. In fact, the very opposite is true. Title VII prohibits discrimination. In effect, it says that race, religion and national origin are not to be used as the basis for hiring and firing. Title VII is designed to encourage hiring on the basis of ability and qualifications, not race or religion.

But Senator Humphrey hardly stood alone in insisting that preferences would

not be mandated by the Act. Several other key supporters of the Act took to the rostrum to insist that nothing like the Revised Philadelphia Plan could be inferred from the Act:

Title VII might justly be described as a modest step forward. Yet it is pictured by its opponents and detractors as an intrusion of numerous Federal inspectors into our economic life. These inspectors would presumably dictate to labor unions and their members with regard to . . . racial balance in job classifications, racial balance in membership, and preferential advancement for members of so-called minority groups. Nothing could be further from the truth. . . Employers and labor organizations could not discriminate in favor of or against a person because of his race, his religion, or his national origin.

${ }^{44}$ Congressional Record (9 April 1964) 110: 7477 (Bipartisan Civil Rights Newsletter No. 9-March 19, 1964). 
In such matters, the Constitution, and the bill now before us drawn to conform to the Constitution, is colorblind. ${ }^{45}$

Several times during the debate, supporters directly challenged the critics' repeated assertion that Title VII would result in race-conscious hiring. Senator Case, a bi-partisan captain of Title VII, was quick to refute Senator Ervin's allegations:

Senator Ervin: The bill is designed to compel employers to hire nonwhites in specific cases, whether they wish to hire them or not; is it not?

Senator Case: The bill would do only one thing. It would make it unlawful for a person to discriminate against an individual in regard to employmenthiring, firing, promotion, or any other matter-because of race. It does not require anybody to hire a particular individual. ${ }^{46}$

But even given these repeated assurances, supporters of the Act were forced to refute these same allegations even after the Tower Amendment had been added. Once again, someone had to defend the Act from unfounded charges:

Mr. President, I have heard over and over again in the last few weeks the charge that title VII . . . would impose a quota system on employers and labor unions. There are two variations of the argument. One is that because Title VII specifically says that "desegregation" shall not mean assignment of students to public schools in order to overcome racial balance, and title VII contains no such disclaimer in relation to employment practices, then it follows that title VII is intended to require hiring to overcome racial balance in the work force. The other variation is that an employer will hire members of minority groups, regardless of their qualifications, to avoid having any problems with the (EEOC). The result, either way, so the argument goes, is that a quota system will be imposed, with employers hiring and unions accepting members, on the basis of the percentage of population represented by each specific minority group.

\footnotetext{
${ }^{45}$ Congressional Record (30 March 1964) 110: 6563-64 (remarks of Senator Kuchel).
}

${ }^{46}$ Congressional Record (8 April 1964) 110: 7253. 
I do not agree with the argument. ${ }^{47}$

Senator Williams of Delaware was probably unique among the Act's supporters. He began his defense by conceding that the Act, as originally passed by the House of Representatives, would virtually require employers to hire minorities based on proportionality. This he criticized as "discrimination in reverse," but then he concluded that the Senate amendment [section 703(j)] was designed to forbid this possibility. He concluded his defense of the Act by quoting a report from a staff member of the Judiciary committee:

One of the more important changes made by the Senate was the protection provided for employers who operate in areas where minorities live. An employer cannot be forced to discharge employees or employ additional employees in order to achieve a racial balance. An employer with 100 employees who may all be white cannot be required to meet a quota even though his plant is located in a neighborhood that is 50 percent Negro. The right of the employer to employ anyone he chooses on the basis of ability is made crystal clear by the Senate amendment. ${ }^{48}$

Normally, when a Civil Rights Act is sent to Congress, it is sent to the Judiciary committees of both houses for public hearings. The testimony from those hearings are often given great weight by courts searching to resolve ambiguities in statutes by examining the legislative intent or purpose. The Civil Rights Act of 1964 was given a warm reception in the House committee, but was not sent to the Senate committee. This was because the supporters of the bill knew that Senator Eastland,

${ }^{47}$ Congressional Record (4 May 1964) 110: 9881 (remarks of Senator Allott).

${ }^{48}$ Congressional Record (18 June 1964) 110: 14,331. 
chairman of the Senate Judiciary committee, was a southern Democrat who had previously squashed many similar bills, or had at least gutted them of any substance. Since there was no testimony in the committee, despite the fact that the Senate made several changes in the Act, two key sponsors added their "Interpretive Memorandum of Title VII" to help guide the courts if they should need any further clarification. It is here that Senators Clark and Case stated that the Revised Philadelphia Plan would be impossible under the Act:

There is no requirement in title VII that an employer maintain a racial balance in his work force. On the contrary, any deliberate attempt to maintain a racial balance, whatever such a balance may be, would involve a violation of title VII because maintaining such a balance would require an employer to hire or to refuse to hire on the basis of race. ${ }^{49}$

Immediately after this Memorandum appeared in the Record, Senator Clark replied to several objections raised by Senator Dirksen. Senator Clark had the objections and replies printed in entirety in the Record:

Objection: Many employers will lean over backwards to avoid discrimination, and as a result will discriminate against other employees. . . .

Answer: . . . the Commission has a clear mandate to engage in widespread educational and promotional activities to encourage understanding and acceptance of the policy of the act, including the obligation not to discriminate against whites.

Objection: The language of the statute is vague and unclear. It may interfere with the employers' right to select on the basis of qualifications.

Answer: Discrimination is a word which has been used in State FEPC statutes for at least 20 years, and has been used in Federal statutes, such as the National Labor Relations Act, for even a longer period. To discriminate is to make distinctions or differences in the treatment of employees, and are

${ }^{49}$ Congressional Record (8 April 1964) 110: 7213 (emphasis added). 
prohibited only if they are based on any of the five forbidden criteria (race, color, religion, sex or national origin): any other criteria or qualification is untouched by this bill.

Objection: The bill would require employers to establish quotas for nonwhites in proportion to the percentage of nonwhites in the labor market area. Answer: Quotas are themselves discriminatory..$^{50}$

And lastly, Senator Humphrey added his own clarifications on "miscellaneous changes" made by the Senate to the Act. In doing so, he re-emphasized the interpretation given by Senators Clark and Case:

A new subsection $703(\mathrm{j})$ is added to deal with the problem of racial balance among employees. The proponents of this bill have carefully stated on numerous occasions that title VII does not require an employer to achieve any sort of racial balance in his work force by giving preferential treatment to any individual or group. Since doubts have persisted, subsection (j) is added to state this point expressly. ${ }^{51}$

Going back to the court's opinion, Judge Weiner also accepted the Labor Department's argument that the Plan did not require the hiring of minorities, but rather required "good faith efforts" to meet certain goals. ${ }^{52}$ Unfortunately, this argument crumbles under its own weight. The "finding" of discrimination in this case was the racial imbalance of the union work force. "Good faith" efforts are not enough if such actions do not have the result of hiring minorities. Critics of the Act seemed to anticipate such actions by the executive branch as a way to circumvent any

${ }^{50}$ Congressional Record (8 April 1964) 110: 7218.

${ }^{51}$ Congressional Record (4 June 1964) 110: 12,723 (emphasis added).

52311 F. Supp. at 1008-9. 
outright requirements of preferences. As Senator Tower argued,

Let us be honest. The bill has a strong element of compulsion. It would compel minority employers to hire members of certain minority groups. It goes further than that. . . . Ultimately, I think the effect of the bill would be to compel an employer in a given community to hire a given percentage of people of every nationality or ethnic background in the community. ${ }^{53}$

Recalcitrant Senators in 1964 were not the only ones to reach this conclusion. Elmer Staats was the Comptroller General of the United States in 1969, which made him head of the General Accounting Office and Congress' chief auditor. His office issued an opinion condemning the Philadelphia Plan as an illegal requirement being placed upon bidders for federal contracts. Comptroller Staats criticized the goals/quotas distinction as "semantics" which "tends to divert attention from the end result of the Plan-that contractors commit themselves to making race or national origin a factor for consideration in obtaining their employees. "54 In fact, Staats'

${ }^{53}$ Congressional Record (13 April 1964) 110: 7778; See also page 8500 (20 April: remarks of Senator Smathers); 8618-19 (21 April: remarks of Senators Stennis and Sparkman); 5614 (18 March: remarks of Senator Ervin).

54 "Contracts-Labor Stipulations-Nondiscrimination-Affirmative Action Programs," Decisions of the Comptroller General 49 (1969): 64-5. Several commentators have criticized the distinction as well; see Note, "Executive Order 11246: AntiDiscrimination Obligations in Government Contracts," 599; Sherain, "The Questionable Legality of Affirmative Action," 39; Note, "Doing Good the Wrong Way: The Case for Delimiting Presidential Power under Executive Order No. 11,246," Vanderbilt Law Review 33 (1980): 926 (n.38), 933; Note, "Developments in the Law: Employment Discrimination and Title VII of the Civil Rights Act of 1964," Harvard Law Review 84 (1971): 1301:

Given the statutory injunctions against hiring based upon considerations other than merit, it is a fair assumption that the danger of transgressing those legal barriers will increase as the evidentiary use of noncompliance with numerical 
argument is entirely consistent with what supporters of the Act insisted in 1964:

Mr. President, it is also charged that employers, including farmers, will have to hire employees according to race to establish racial balance in every job classification. . . .

Now I turn to the fact: For some reason, the fact that there is nothing whatever in the bill which provides for racial balance or quotas in employment has not been understood by those opposed to civil rights legislation. They persist in opposing a provision which is not only not contained in the bill, but is specifically excluded from it. those opposed to (the Act) should realize that to hire a Negro solely because he is a Negro is racial discrimination, just as much as a "white only" employment policy. Both forms of discrimination are prohibited by Title VII. . . . But how can the language of equality favor one race or religion over another? Equality can have only one meaning, and that meaning is self-evident to reasonable men. Those who say that equality means favoritism do violence to commonsense. ${ }^{55}$

Judge Weiner further attempted to defend the goals/quotas distinction by citing

Weiner v. Cuyahoga Community College District to support his conclusion that the contractors were not actually being forced to hire on the basis of race. ${ }^{56}$ It is difficult to understand why Judge Weiner would do this. In that case, the Ohio courts upheld the "Cleveland Plan." The lowest bidder on a state construction contract refused to submit an affirmative action plan that had "the result of assuring that there is minority group representation in all trades on the job and in all phases of the work. "57 This lowest bidder was then passed over in favor of a contractor who requirements hardens towards the position of an irrebuttable presumption.

${ }^{55}$ Congressional Record (23 April 1964) 110: 8921 (remarks of Senator Williams).

${ }^{56} 15$ Ohio Misc. 289, 238 N.E.2d 839; affirmed 19 Ohio St. 2d 35, 249 N.E.2d 907 (1969); certiorari denied 396 U.S. 1004 (1970); cited at 311 F. Supp. 1008.

${ }^{57} 249$ N.E.2d at 908 (emphasis in original). 
specifically promised to have "Negro representatives in all crafts" on the worksite. ${ }^{58}$ That is to say, the winning contractor was required to hire at least some sort of minimum number of "Negro representatives" in order to win the contract. This is a requirement for at least some minimum number of minorities and not merely a "goal."

There are other peculiarities in Judge Weiner's opinion. Not only did he accept a rather flimsy finding of discrimination, he accepted the Labor Department's argument that the remedy should go against the contractors and not the union. The Philadelphia Plan stated that "it is no excuse that the union with which the contractor has a collective bargaining agreement failed to refer minority employees. " 59 This ignores the fundamental principle of tort law that the remedy must go against the wrongdoer. As a matter of common law, if the unions were the discriminators, the remedy would be placed upon them. The contractors had nothing to do with the alleged discriminatory practices of the unions. ${ }^{60}$ Judge Weiner ruled that this was simply irrelevant, ${ }^{61}$ yet supporters of the Act insisted that a situation such as this could not happen:

${ }^{58}$ Graham, The Civil Rights Era, 540-41 (n. 49). 63.

59 "Contracts-Labor Stipulation-Nondiscrimination-Affirmative Action Programs," 67.

60"Contracts-Labor Stipulations-Nondiscrimination-Affirmative Action Programs,"

61311 F. Supp. at 1011. 
Question: If an employer obtains his employee from a union hiring hall through operation of his labor contract, is he in fact the true employer from the standpoint of discrimination because of race, color, religion, or national origin when he exercises no choice in their selection? If the hiring hall sends only white males, is the employer guilty of discrimination within the meaning of this title? If he is not, then further safeguards must be provided to protect him from endless prosecution under the authority of this title.

Answer: An employer who obtains his employees from a union hiring hall through operation of a labor contract is still an employer. If the hiring hall discriminates against Negroes, and sends him only whites, he is not guilty of discrimination-but the union hiring hall would be. ${ }^{62}$

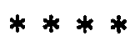

Having thus ignored section $703(\mathrm{j})$ and the unambiguous legislative intent of

the Civil Rights Act, Judge Weiner concluded his opinion with a flourish:

We also reject the plaintiffs' assertion that the Plan is contrary to the express or implied will of Congress. We would say that the opposite view is an accurate portrayal of the policy of our government. Its announced policy is to assure nondiscriminatory employment practices. ${ }^{63}$

The Contractors' Association promptly appealed.

Contractors' Association v. Shultz ${ }^{64}$

${ }^{62}$ Congressional Record (8 April 1964) 110: 7217 (Senator Clark's "Response to Dirksen Memorandum"); see also page 14,311 (18 June: remarks of Senator Williams), quoting a memorandum from a staff member of the Senate Judiciary committee:

The Senate amendment also forbids discrimination by unions, and relieves an employer of any liability where he is precluded by a labor contract from procuring employees, if there is discrimination in such a case it is the union that is responsible.

${ }^{63} 311$ F. Supp. at 1012.

${ }^{64} 442$ F.2d 159 (3d cir. 1971). 
The third circuit court, on appeal, upheld the Plan in its entirety. In doing so, the court added a few new twists to the district court's defense of the Plan.

The core of the decision revolved around the court's analysis of executive power and E.O. 11,246. As this was a question of executive versus legislative power, the court turned to Justice Jackson's concurring opinion in Youngstown Sheet \& Tube v. Sawyer. ${ }^{65}$ In that case, Justice Jackson noted that executive orders fit into three broad categories:

1. When the President acts pursuant to an express or implied authorization of Congress, his authority is at its maximum, for it includes all that he possesses in his own right plus all that Congress can delegate.

2. When the President acts in absence of either a congressional grant or denial of authority, he can only rely upon his own independent powers, but there is a zone of twilight in which he and Congress may have concurrent authority, or in which its distribution is uncertain.

3. When the President takes measures incompatible with the expressed or implied will of Congress, his power is at its lowest ebb, for then he can rely only upon his own constitutional powers minus any constitutional powers of Congress over the matter. ${ }^{66}$

It would seem that the Philadelphia Plan fell into Justice Jackson's third category. That is, Congress in section 703(j) stated that employers could not be forced to hire to correct any sort of "racial imbalance." The court thought otherwise.

Judge Gibbons, writing for the court, chose to base the validity of the Philadelphia Plan on E.O. 11,246. This, in turn, was based on the validity of E.O.

${ }^{65} 343$ U.S. 579 (1952).

${ }^{66} 343$ U.S. at 635-38; cited at 442 F.2d 168. 
10,925 , which was in force when the Act was passed. ${ }^{67}$

The validity of E.O. 10,925 was beyond doubt. This was Kennedy's order, which was in effect at the time the Civil Rights Act of 1964 was debated and passed. The Act itself specifically referred to E.O. 10,925, and Congress consented to both its purpose and effect. ${ }^{68}$ But as has been already noted, E.O. 10,925 says nothing whatsoever about racial balance or underutilization. ${ }^{69}$ It says only that contractors take affirmative action "to ensure applicants are employed, and that employees are treated during employment without regard to their race, color, or national origin."

The validity of E.O. 11,246 is not as certain as 10,925 . On the one hand, 11,246 repeats the antidiscrimination language of 10,925 verbatim. If read this way, 11,246 is every bit as valid as 10,925 , as it imposes no new obligations, and does not conflict with the 1964 Act. However, the court chose to exploit the ambiguity of 11,246 and read the Order in a way flatly inconsistent with 703(j). But even at that, the court ruled that 703(j) was irrelevant.

The court stated that 703(j) did not apply, because it was a limitation that applied solely to Title VII, and not to other remedies. ${ }^{70}$ Instead, Judge Gibbons based the Plan on Lyndon Johnson's authority to issue 11,246 . In doing so, the court

\footnotetext{
${ }^{67} 442$ F.2d at $170-71$.

${ }^{68} 442$ F. $2 d$ at 171.

${ }^{69}$ See also Graham, The Civil Rights Era, at 332.

${ }^{70} 442$ F.2d at 172.
} 
decided that the President may issue executive orders that state exactly the opposite of what Congress has decreed. This falls into Justice Jackson's third category, where the President's power is at its lowest ebb. ${ }^{71}$ As Justice Frankfurter noted in his concurring opinion in Youngstown:

It is one thing to draw an intention of Congress from general language and say that Congress would have explicitly written what is inferred, where Congress has not addressed itself to a specific situation. It is quite impossible, however, where Congress did specifically address itself to a problem ... . to find secreted in the interstices of legislation the very grant of power which Congress consciously withheld. To find (here) authority so explicitly withheld is . . . to disrespect the whole legislative process and the constitutional division of authority between President and Congress. ${ }^{72}$

In order to circumvent this obstacle, the court simply ignored the offending statute.

The conclusion that the court deliberately ignored key sections in Title VII becomes all the more certain further along in the opinion. As noted earlier, section $706(\mathrm{~g})^{73}$ states that the courts shall order remedies based on the qualification that "the respondent has intentionally discriminated or is intentionally discriminating" against any individual or group. Judge Gibbons decided that this should be written out of the Act as well: "The absence of a judicial finding of past discrimination is also

${ }^{71}$ See also Note, "Executive Order 11246: Anti-Discrimination Obligations in Government Contracts," 597-99; Brody, "Congress, The President, and Federal Equal Employment Policymaking," 270-81, 290.

${ }^{72} 343$ U.S. at 609.

${ }^{73}$ United States Code 42: 2000e-5(g). 
legally irrelevant." 74 And, once again, this flew in the face of what Congress had decreed:

Section $706(\mathrm{~g})$ is amended to require a showing of intentional violation of the title in order to obtain relief. This is a clarifying change. Since the title bars only discrimination because of race, color, religion, sex, or national origin it would seem already to require intent, and, thus, the proposed change does not involve any substantive change in the title. The express requirement of intent is designed to make it wholly clear that inadvertent or accidental discriminations will not violate the tile or result in entry of court orders. It means simply that respondent must have intended to discriminate. ${ }^{75}$

Much like Judge Weiner's district court opinion, it can safely be said that Judge Gibbons' appellate court decision went to some lengths to ignore both the text and history of the Civil Rights Act of 1964. Having done so, Judge Gibbons replicated Judge Weiner's ignorance and concluded with his own triumph of fiat:

${ }^{74} 442$ F.2d at 175.

${ }^{75}$ Congressional Record (4 June 1964) 110: 12,723 (remarks of Senator Humphrey); see also Comment, "Enforcement of Fair Employment Under the Civil Rights Act of 1964," Chicago Law Review 32 (1965): 458-60. See also Congressional Record (16 April 1964) 110: 8194 (remarks of Senator Dirksen):

The words "wilful" and "wilfully" as ordinarily employed, mean nothing more than that the person . . . knows what he is doing, intends what he is doing . ... (and) thus the terms imply a conscious act of the mind. . . . Thus the terms signify an act done knowingly, permissively, voluntarily, deliberately, persistently, perversely, obstinately, or even an act performed stubbornly. The terms also signify an act done by design, with set purpose.

"The terms are also employed to denote an intentional act, an act done intentionally, or purposely, as distinguished from an accidental act, an act done by accident, or accidentally, or carelessly, thoughtlessly, heedlessly, or inadvertently, or otherwise beyond the control of the person charged." 
We discern no such intention either from the language of the statute or from its legislative history. Clearly the Philadelphia Plan is color-conscious. Indeed the only meaning which can be attributed to the "affirmative action" language which since March of 1961 has been included in successive Executive Orders is that Government contractors must be color-conscious. ${ }^{76}$

The Supreme Court, without comment, refused to review the decision. ${ }^{77}$ In doing so, the court upheld the court of appeals' decision to erase 703(j) and the word "intentional" from Title VII of the Act. And having won in Philadelphia, the Labor Department has not since bothered to conduct hearings to first find actual discrimination before imposing such a Plan. ${ }^{78}$ As one staff member of the EEOC explained to the editors of the Harvard Law Review, "the anti-preferential hiring provisions are a big zero, a nothing, a nullity. They don't mean anything at all to us. "79

Considering the court decisions upholding the Philadelphia Plan, the courts consider

${ }^{76} 442$ F.2d at 173.

${ }^{77}$ Contractors' Association of Eastern Pennsylvania v. Hodgson, 404 U.S. 854 (1971).

${ }^{78}$ Note, "Doing Good the Wrong Way," 927 (n. 44); see also Graham, The Civil Rights Era, at 438:

Once the Labor Department had won its point in Philadelphia, however, it never bothered with the procedure again. The hearings and findings in Philadelphia would suffice for the rest of the country. As (Labor Solicitor Laurence) Silberman put it, "with [the Philadelphia Plan] battle won, we went on to spread construction plans across the country like Johnny Appleseed." "We no longer even purported to base these orders," Silberman admitted, "on findings of discrimination."

${ }^{79}$ Note, "Developments in the Law," 1165 (n. 279). 
the anti-preferential hiring provisions meaningless as well. 


\section{CHAPTER 3}

\section{GRIGGS}

The Griggs decision of 1970 was the first landmark decision by the Supreme Court interpreting Title VII of the Civil Rights Act of 1964. Much like the Philadelphia Plan, the implications of Griggs went far beyond the actual facts of the case. And, again like the Philadelphia Plan, a study of this decision from its inception is revealing.

\section{Griggs v. Duke Power ${ }^{\text {so }}$}

Duke Power Company is a public utility in North Carolina which generates and transmits electric power to its customers. In 1967 the company was sued in a class-action suit by thirteen of its fourteen black employees at the Dan River Station in Draper, North Carolina, who alleged that their rights under Title VII has been violated. The suit challenged Duke Power Company's use of standardized tests in hiring and promotion as discriminatory.

Prior to 1964, Duke Power maintained a segregated work force. ${ }^{81}$ All black employees were confined to the Labor Department, which was the lowest-paid division. All fourteen of Duke Power's black employees were in this division in

${ }^{80} 292$ F. Supp. 243 (M.D.N.C. 1968).

${ }^{81} 292$ F. Supp. at 247. 
1964. On the day when the Civil Rights Act of 1964 became effective, the company mandated passing scores on the E.F. Wonderlic Personnel general intelligence and Bennett mechanical comprehension tests in order to be hired by the company, or to transfer out of the Labor Department. This was challenged as discriminatory. ${ }^{82}$

On initial examination, the case would appear to be without merit. One section of Title VII deals specifically with employment testing:

Notwithstanding any other provision of this title, it shall not be an unlawful employment practice for an employer ... . to give and to act upon the results of any professionally developed ability test provided that such test, its administration or action upon the results is not designed, intended or used to discriminate because of race, color, religion, sex or national origin. . . ${ }^{83}$

The plaintiffs in this case, however, insisted that section 703(h) should be read in light of section 703(a):

It shall be an unlawful employment practice for an employer-

(1) to fail or refuse Ło hire or to discharge any individual, or otherwise to discriminate against any individual with respect to his compensation, terms, conditions, or privileges of employment, because of such individual's race, color, religion, sex, or national origin; or

(2) to limit, segregate, or classify his employees in any way which would deprive or tend to deprive any individual of employment opportunities or otherwise adversely affect his status as an employee, because of such

${ }^{82} 292$ F. Supp. at 244-47. The case also involved a separate side issue of whether it would be discriminatory for Duke Power to require a high school diploma of anyone wishing to transfer departments. This requirement was soon withdrawn by the company in favor of passing scores on the two tests only, and presents no real issue in my discussion regarding the legality of aptitude tests.

${ }^{83}$ United States Code 42: 2000e-2(h). 
individual's race, color, religion, sex, or national origin. ${ }^{184}$

The argument advanced by the plaintiff's lawyers relied heavily on section 2 , which prohibits practices that "deprive or tend to deprive any individual of employment opportunities or otherwise adversely affect his status as an employee."

Reading sections 703(a) and 703(h) together, the plaintiffs argued that section 703(h) should protect only professionally developed abilities tests that directly measured potential job performance. ${ }^{85}$ This was entirely consistent with the construction given to $703(\mathrm{~h})$ by the EEOC:

The Commission accordingly interprets "professionally developed ability test" to mean a test which fairly measures the knowledge or skills required by the particular job or class of jobs which the applicant seeks, or which fairly affords the employer a chance to measure the applicant's ability to perform a particular job or class of jobs. The fact that a test was prepared by an individual or organization claiming expertise in test preparation does not, without more, justify its use within the meaning of Title VII. ${ }^{86}$

Implicit in the EEOC's argument was the argument that these tests could be used by unscrupulous employers to be a subterfuge for maintaining a segregated work force. Even the editors of the Harvard Law Review, while criticizing the final

${ }^{84}$ United States Code 42: 2000e-2(a).

${ }^{85}$ George Cooper and Richard Sobol, "Seniority and Testing Under Fair Employment Laws: A General Approach to Objective Criteria of Hiring and Promotion," Harvard Law Review 82 (1969): 1649. Cooper and Sobol were attorneys for the Duke Power plaintiffs and other persons claiming Title VII violations in other cases at the time.

${ }^{86}$ EEOC Guidelines on Employment Testing Procedures, as cited by Cooper and Sobol, "Seniority and Testing under Fair Employment Laws," 1653-54. 
resolution of this case, conceded that "there is an obvious danger that biased employers will set testing standards for menial jobs, knowing that few blacks can meet their requirements. ${ }^{187}$

The plaintiffs in Griggs argued that these tests were being "used" to discriminate against blacks. The word "used" has two possible meanings in this context. On the one hand, plaintiffs argued that the test was being "used" in the sense that these tests had the effect of "depriving" black employees of employment opportunities. As Griggs' attorneys argued, "any test causing this result ('disproportionate screening of blacks') is being 'used' to discriminate, whether or not so intended. ${ }^{188}$

This interpretation, so far as it goes, seems plausible. ${ }^{89}$ Unfortunately, it ignores section $706(\mathrm{~g})$, which states that the court must find that "respondent has intentionally engaged or is intentionally engaging in an unlawful employment practice. "90 When combined with this requirement, a test is "used" to "deprive" a person on the basis of race if and only if it is "used" with the intent to do so. The

${ }^{87}$ Note, "Developments in the Law," 1128.

${ }^{88}$ Cooper and Sobol, "Seniority and Testing under Fair Employment Laws," 1653.

${ }^{89}$ But see Gold, "Griggs' Folly: An Essay on the Theory, Problems, and Origin of the Adverse Impact Definition of Employment Discrimination and a Recommendation for Reform," Industrial Relations Law Journal 7 (1985): 486, which argues that such a reading ignores the ordinary meaning of the word "used."

${ }^{90}$ United States Code 42: $2000 \mathrm{e}-5(\mathrm{~g})$. 
word "used," by itself, seems to suggest at least some form of intent, and section 706(g) makes this requirement explicit.91 Griggs' argument that these tests are discriminatory, "whether or not so intended," is simply wrong..$^{2}$

The federal district court, in rejecting Griggs' claim, adopted this latter reading of section $703(\mathrm{~h})$ in its entirety. Judge Gordon began his opinion by noting that blacks at Duke Power had been segregated in the lowest-paying department, but since this was done prior to passage of the Act, it was not illegal at the time and thus beyond the remedial powers of the court:

In providing for prospective application only, Congress faced the cold hard fact of past discrimination and the resulting inequities. Congress also realized the practical impossibility of eradicating all the consequences of past discrimination. . . .

It is obvious that where discrimination existed in the past, the effects of it will be carried over into the present. But it is also clear that policies of discrimination which existed in the past cannot be continued into the present under the 1964 Act. Plaintiffs do labor under the inequities resulting from the past discriminatory promotional policies of the defendant, but the defendant discontinued those discriminatory practices. . . .

The requirement was made applicable to a departmentalized work force

${ }^{91}$ See also Gold, "Griggs' Folly," at 492: "Intent is part of the statue, and 'intentionally' was added to section $706(\mathrm{~g})$ so the courts would not forget it."

${ }^{92}$ See also Comment, "Enforcement of Fair Employment Under the Civil Rights Act of 1964," at 459-60 (n. 210):

If the requirement of intent had not been added to the bill a strong case could have been made that since the statute's general policy is remedial and preventative, rather than punitive, relief for the plaintiff would be appropriate even for unintended violations. . . . But because of the amendment, if a defendant can prove affirmatively that the discrimination alleged was not purposeful, the decision should be in his favor even if discrimination did in fact occur. 
without any intention or design to discriminate against Negro employees. The departments serve as a reasonable system of classification with each department having a different function and each department requiring different skills. ${ }^{93}$

Although Duke Power had not done any sort of "validation" to determine whether such tests were good predictors of job performance, Judge Gordon made ruled that "validation" was not a requirement under the Act. The court rejected the EEOC's guidelines, and ruled that the Act nowhere states that tests be job-related, or that an employer can use only a validated test and no other. The Act itself states only that these aptitude tests not be used with the intent to discriminate. ${ }^{94}$ It is plausible that a general intelligence test set at the level of an average high-school student would be as fair to blacks as a requirement of a high school diploma.

Even if there was a requirement that testing be job-related, the court concluded that these tests met that criteria as well. Since the defendants did not prove that these tests were the product of illegal intent, the court accepted Duke Power's argument that these tests were both reasonable and legitimate. For example, Duke Power's expert witness testified that the Wonderlic test was designed to measure a person's ability to reason and use good judgement. Duke Power argued that it was trying to generally upgrade the quality of its work force. Furthermore, it would make good business sense to hire only those employees who have the potential to move up

${ }^{93} 292$ F. Supp. at $247-48$.

${ }^{94} 292$ F. Supp. at 250. 
through the ranks of the company. There was no reason to question the validity of

Duke Power's imposition of this test:

The two tests used by the defendant were never intended to accurately measure the ability of an employee to perform the particular job available. Rather, they are intended to indicate whether the employee has the general intelligence and overall mechanical comprehension of the average high school graduate, regardless of race, color, religion, sex, or national origin. . . .

The Act does not deny an employer the right to determine the qualities, skills, and abilities required of his employees. . . .

These qualities are general in nature and are not indicative of a person's ability to perform a particular task. Nevertheless, they are qualities which the defendant would logicaliy want to find in his employees. ${ }^{95}$

The Bennett mechanical comprehension test was even easier to justify. Duke

Power is, after all, a power plant, and it would seem entirely reasonable for the company to hire only persons who can demonstrate at least some mechanical aptitude. In an industrial environment such as a power plant, employees who lack mechanical aptitude are likely to get hurt. The court also noted that employees in the Labor Department are often brought in to assist employees in the Coal Handling Department during peak times. ${ }^{96}$ There would be times when employees of the Labor Department would need to display some sort of mechanical aptitude when using industrial machinery designed to move coal. The court accepted Duke Power's argument that these tests served a legitimate employer interest.

The fact that the tests were imposed on the day the 1964 Act took effect was

\footnotetext{
${ }^{95} 292$ F. Supp. at 250.

${ }^{96} 292$ F. Supp. at 251.
} 
not enough in the court's mind to prove intent. Even though Duke Power had segregated its employees before the Act, they were still entitled to a presumption of innocence, and had demonstrated to the court that there were nondiscriminatory motives for imposing these tests. Since Title VII mandated racially neutral and objective hiring standards, it was not difficult for the court to accept Duke Power's new reliance on aptitude tests, so long as they were fairly administered.

The plaintiffs promptly appealed to the fourth circuit court.

Griggs v. Duke Power ${ }^{97}$

The fourth circuit court, in upholding the core of the district court's opinion, based its decision not only on Judge Gordon's reasoning, but also upon some other key evidence as well.

Duke Power's attorneys added a new twist to their defense of standardized testing: aside from testing general intelligence and competence, they measure promotability as well. Since Duke Power's standard practice was to promote from within its own ranks, the court accepted the company's argument that the tests screened out those who lacked any real chance at being promoted to supervisory positions. ${ }^{98}$ Moreover, Judge Boreman's opinion noted that Duke Power had hired an expert before imposing these tests, and that his conclusions that such tests would

${ }^{97} 420$ F.2d 1225 (4th cir. 1970).

${ }^{98} 420$ F.2d at 1232 . 
be useful for the company was "uncontroverted in the record." 99

The clincher for the court was the revelation that Duke Power had instituted a policy of paying a 75 percent of school expenses for any employee who wanted to pursue his high school education or equivalent. As the court noted, it would be "illogical" to conclude that Duke Power was discriminating against blacks when "it was willing to pay for the education of incumbent Negro employees who could thus become eligible for advancement." 100 The court of appeals wanted proof of actual discrimination, and not a case built upon statistics alone.

Chief Judge Sobeloff, who as Solicitor General had participated in the Brown decision of 1954, dissented from Judge Boreman's decision. Sobeloff's dissent was more passion than reason:

On this issue hangs the vitality of (Title VII): whether the Act shall remain a potent tool for equalization of employment opportunity or shall be reduced to mellifluous but hollow rhetoric. ${ }^{101}$

Sobeloff believed that the intent requirement of Title VII should simply be ignored. He specifically did not argue that these tests were imposed "deliberately" to evade Title VII, but that the employer's state of mind was "irrelevant" and that "the

${ }^{99} 420$ F.2d at 1233.

${ }^{100} 420$ F.2d at 1233 (n. 6). The court noted that at least one of the black plaintiffs had taken advantage of the offer and obtained his degree.

${ }^{101} 420$ F.2d at $1237-38$. 
effect of his actions is not different from purposeful discrimination." 102

This would seem to explain the inherent contradiction of Sobeloff's dissent. On the one hand, he argued that the intent requirement of Title VII was irrelevant, and yet he also stated that he felt these tests were "cunning devices" designed with the appearance of neutrality. ${ }^{103}$ In other words, they were intended to discriminate, even though proof of such intent is unnecessary.

Sobeloff's dissent stated that "the statute is unambiguous" in prohibiting "'objective' or 'neutral' standards that favor whites" but serve no business purposes. ${ }^{104}$ Unfortunately, none of this is actually in this "unambiguous" statute. Section $706(\mathrm{~g})$ is unambiguous in requiring active intent before the court can award relief. And as for the alleged ambiguity of section $703(\mathrm{~h})$, it says nowhere that tests must be job related. Nor does it say that there must be some sort of validation procedure. It is not at all obvious how a law can unambiguously say something that it does not say.

The very core of Sobeloff's dissent can be found in his statement criticizing the majority for "their expressed belief in the good faith of Duke Power. "105 What is deeply disturbing about this assertion is its implication that because of the long

\footnotetext{
102420 F.2d at 1238 .

${ }^{103} 420$ F.2d at 1238.

${ }^{104} 420$ F.2d at 1238.

${ }^{105} 420$ F.2d at 1246.
} 
history of segregation, Duke Power (and, presumably, every other employer nationwide) is no longer entitled to an assumption of innocence. In other words, the plaintiffs did not need to prove what they could not prove. Employers are guilty whenever they do anything that might have a detrimental effect on blacks. Companies that have discriminated in the past are now considered guilty until proven innocent. This position violates the concept of due process at its most basic level, and yet it is the position that the U.S. Supreme Court would ultimately take.

Griggs v. Duke Power ${ }^{106}$

The prospects for success were so poor before the Supreme Court that key people within the EEOC suggested that it would be better to accept the loss and not risk an even greater defeat. ${ }^{107}$ The Justice Department pressed on regardless, and stunned a great many people by winning a unanimous victory before the high court.

It had been widely reported that Chief Justice Burger was determined to uphold the appellate court decision, but switched his vote when he was unable to get a majority to vote with him. ${ }^{108}$ This makes his sweeping opinion all the more difficult to believe.

Chief Justice Burger's opinion for the court was a bald display of fiat. He began his substantive analysis thus:

${ }^{106} 401$ U.S. 424 (1971).

${ }^{107}$ Graham, The Civil Rights Era, 385.

${ }^{108}$ Graham, The Civil Rights Era, 386-87. 
The objective of Congress in the enactment of Title VII is plain from the language of the statute. It was to achieve equality of employment opportunities and remove barriers that have operated in the past to favor an identifiable group of white employees over other employees. Under the Act, practices, procedures, or tests neutral on their face, and even neutral in terms of intent, cannot be maintained if they operate to "freeze" the status quo of prior discriminatory employment practices. ${ }^{109}$

Burger stressed repeatedly that the plaintiffs did not need to find intent, as the Act supposedly prohibits "not only overt discrimination but also practices that are fair in form, but discriminatory in operation. "110 Burger's entire opinion has often been reduced to just one of his lines: "If an employment practice which operates to exclude Negroes cannot be shown to be related to job performance, the practice is prohibited." 111 The court continued:

. . . but good intent or absence of discriminatory intent does not redeem employment procedures or testing mechanisms that operate as "built-in headwinds" for minority groups and are unrelated to measuring job capability. $\cdots$

.. . But Congress directed the thrust of the Act to the consequences of employment practices, not simply the motivation. More than that, Congress has placed on the employer the burden of showing that any given requirement must have a manifest relationship to the employment in question. . . . ... The facts of this case demonstrate the inadequacy of broad and general testing devices as well as the infirmity of using diplomas or degrees as fixed measures of capability. . . Diplomas and tests are useful servants, but Congress has mandated the commonsense proposition that they are not to become masters of reality. ${ }^{112}$

${ }^{109} 401$ U.S. at $429-30$.

110401 U.S. at 431.

${ }^{111} 401$ U.S. at 431.

${ }^{112} 401$ U.S. at 432-33. 
Burger's failed reference to the "plain meaning" of 703(h) was bad enough; his failure to address the "plain meaning" of $706(\mathrm{~g})$ and its intent requirement was unforgivable. But even Burger's flimsy attempt at textual analysis pales in comparison to his attempt at legislative history.

In 1965, Alfred Kelly published a seminal article regarding the Supreme Court and historical analysis. He argued that judges rarely, if ever, have any meaningful experience with impartial historical analysis. Judges usually read the relevant historical materials in the same manner as a lawyer is taught to look for anything that advances an argument. Conversely, anything potentially detrimental to the argument is ignored. Kelly ridiculed this method as "law office" history, and concluded that the courts often try to couch strained or dubious readings of law under the guise of historical neutrality. ${ }^{113}$ This provides an excellent explanation of Burger's opinion in Griggs.

Perhaps the most striking feature of Burger's "history" is its extraordinary brevity. Employment testing was one of the most fiercely debated topics in 1964 discussed in conjunction with the Act, yet Burger's attempt at statutory history was accomplished in less than three pages. Even most "law office" history is more thorough than this.

Burger began by noting that Duke Power based its defense in part on the

${ }^{113}$ Alfred Kelly, "Clio and the Court: An Illicit Love Affair," Supreme Court Review (1965): 119-58. 
crucial Clark/Case Interpretive Memorandum:

There is no requirement in Title VII that employers abandon bona fide qualification tests where, because of differences in background and education, members of some groups are able to perform better on these tests than members of other groups. An employer may set his qualifications as high as he likes, he may test to determine which applicants have these qualifications, and he may hire, assign, and promote on the basis of test performance. ${ }^{114}$

This was precisely the situation in Griggs. As this was an obstacle that needed to be minimized, Burger suggested that "nothing there stated conflicts with the later memorandum dealing specifically with the debate over employer testing, in which Senators Clark and Case explained that tests which measure 'applicable job qualifications' are permissible under Title VII."115 This is true, but Burger missed the point. The Congress that wrote this Act insisted adamantly that employers may use whatever "applicable job qualifications" they like; the EEOC cannot tell employers that they may not use certain tests as criteria.

It is clear beyond doubt that Section 703(h) was written specifically in response to a controversy regarding hiring practices at Motorola in 1964. All applicants at Motorola were automatically given a general intelligence test, and a passing score was necessary for any further consideration. An Illinois FEPC examiner had ruled that Motorola's general intelligence test was discriminatory, and

${ }^{114}$ Congressional Record (8 April 1964) 110: 7213. Senator Clark, in responding to objections made by Senator Dirksen, explicitly endorsed this interpretation; see page 7216.

${ }^{115} 401$ U.S. at 435. 
critics of the Act quickly seized upon this ruling as evidence of what would happen if the Act did not protect such tests. The entire debate regarding 703(h) revolved around Myart v. Motorola. Incredibly, Burger dismissed the entire Motorola debate with a single footnote. ${ }^{116}$ In order to understand why Griggs was flawed, we must go back to the Myart case.

Leon Myart, a black man, applied for a job as analyzer and phaser for Motorola's television assembly line. This position involved "trouble shooting" televisions as they came off the assembly line. When he went to apply, he was given Motorola's general intelligence test No. 4. All applicants were required to answer at least six of the ten questions correctly, and Motorola claimed that Myart received a failing score of four. Myart soon filed a complaint with the Illinois FEPC.

Myart claimed that he had, in fact, passed the test, and that Motorola had lied about it. The FEPC mediator, Robert Bryant, then gave Myart the test in Bryant's office. This time, Myart passed. A key problem for Motorola was that it did not save Myart's original answer sheet; it had been discarded along with thousands of others as part of Motorola's standard procedure. However, Bryant did not confine himself to this narrow issue, but rather decided to address the much broader issue of testing in general. Considering what the EEOC was arguing in Griggs, the Myart decision was prophetic:

Copyrighted as it was in 1949 and used since that time, test No. 10 in the light

${ }^{116} 401$ U.S. at 435 (n. 10). 
of today's knowledge, is obsolete. Its norm was derived from standardization on advantaged groups. . . . In the light of current circumstances and the objectives of the spirit as well as the letter of the law, this test does not lend itself to equal opportunity to qualify for the hitherto culturally deprived and disadvantaged groups. . . .

If the Fair Employment Practices Act of this State is effectually to be implemented, personnel executives in the industries covered by the law, have a supreme responsibility to move positively to eradicate unfair employment practices in every department. Somehow, general convictions of economic need and fairness must be acquired, and concerted action made to come into play within each department throughout the plant and with the administrators of this law. ... . The task is one of adapting procedures within a policy framework to fit the requirements of finding and employing workers heretofore deprived because of race, color, religion, national origin or ancestry.

Selection techniques may have to be modified at the outset in the light of experience, education, or attitudes of the group. . . . The employer may have to establish in-plant training programs and employ the heretofore culturally deprived and disadvantaged persons as learners, placing them under such supervision that will enable them to achieve job success. ${ }^{117}$

This ruling was issued during the debates over the 1964 Act, and it landed like

a bombshell. Not one Senator defended the Illinois FEPC ruling. ${ }^{118}$ Like

"discrimination" and racial balance, critics of the Act seized upon the Motorola case

as an example of how employment discrimination law can be twisted by bureaucrats:

If we take away from employers the right to prescribe the qualifications of the people whom they employ, which qualifications they prescribe in their own best judgement, and carry out in their own way the search for the people who can meet the qualifications and serve them best, we shall have left private enterprise and gone to a controlled economy under which the Federal Government, through its minions, thousands in number . . . would in effect be telling employers whom they could employ and whom they could not

${ }^{117}$ Congressional Record (19 March 1964) 110: 5664.

${ }^{118}$ See Gold, "Griggs' Folly," at 546. 
employ. ${ }^{119}$

Senator Ervin, who had been a vocal critic of racial balancing when debating 703(a), was also vocal in his denouncing the Motorola case and the possibility that such a thing could happen again under Title VII:

Every time any kind of test is used by an employer to determine the aptitude and capacity of his employees, an employee who is rejected by that test may come in and set the law in motion upon the allegation that he has been discriminated against because of his race. ${ }^{120}$

Criticism of the Motorola decision was not at all confined to the Act's

opponents. These Senators only mirrored public criticism of the decision, and they

took great delight in citing newspaper editorials from across the nation which

defended Motorola. Among the most common:

A foretaste of what will occur if the EEOC is created by Federal law was shown recently by a ruling made in Illinois. . . .

Merit and ability and Motorola's standards of performance were cast aside and the employer lost his rights. This case, which is now pending before the full Commission, has created quite a furor in Illinois, and the warning is clear.

If a State commission can riddle good management practices in the cause of social significance, you can visualize the degree to which employers and unions will be shackled by a horde of inspectors operating under Federal law. ... .

It can be used by well organized and amply financed Negro groups to

${ }^{119}$ Congressional Record (6 April 1964) 110: 7014 (remarks of Senator Holland).

${ }^{120}$ Congressional Record (18 March 1964) 110: 5616 (remarks of Senator Ervin); see also remarks of Senator Fulbright, at page 9600:

I cannot imagine anything more idiotic than to say that an aptitude test is not a legitimate way for a company to determine those who are fitted for employment in that company. 
harass business and industry suspected of unfair practices. ${ }^{121}$

An editorial from the New York Times sounded the same theme:

The Illinois Fair Employment Practices Commission has just furnished a graphic illustration that when a political arm of government assumes jurisdiction over the hiring and firing policies of private business, the tendency is to expand this authority into autocratic control. . . .

. . . a federal bureaucracy would be legislated into senior partnership with private business, with the power to dictate the standards by which employers reach their judgements of the capabilities of applicants for jobs, and the quality of performance after employment, whenever the issue of "discrimination" is raised. ${ }^{122}$

Another editorial, from the widely read Chicago Tribune, was also added to the Record:

This may be reduced to the absurdity that any test acceptable to the FEPC would be one which brought out no distinctions whatsoever among competing applicants and would therefore be meaningless. How, then, is the employer to develop any basis for making a choice in hiring? . . .

As merit and ability demonstrated by testing is out the window, this would seem to be a prescription for reverse discrimination-i.e., that race, color, religion, or something else be given a priority over judgements of a job applicant's prospective usefulness to his employer. . . .

The ruling in Illinois demonstrates that once the snout is in the tent, the rest of the camel will quickly follow. ${ }^{123}$

Supporters of the Act did not let such charges go unanswered. In fact, many

${ }^{121}$ John Knight, "Editor's Notebook," March 22, 1964, in several Knight newspapers nationwide; reproduced at Congressional Record (6 April 1964) 110: 7012-13.

${ }^{122}$ Arthur Krock, "A Pilot Ruling on Equal Employment Opportunity," March 13, 1964, New York Times; reproduced at Congressional Record (6 April 1964) 110:

7016. See also Congressional Record (29 April 1964) 110: 9599.

123 "The State Will Do Your Hiring," Chicago Tribune, March 7, 1964; reproduced at Congressional Record (18 March 1964) 110: 5615. 
key sponsors openly agreed with the critics that these tests were useful for employers and should be protected, and they insisted loudly that section 703(h) would protect the use of such tests in the absence of discriminatory intent.

Senator Humphrey, a key proponent of the Act, was among the first to insist that Title VII could not be interpreted to prohibit aptitude testing. In direct debate with Senator Smathers, Senator Humphrey told his colleagues that "the hearing examiner's decision in the Motorola case disturbs me." His explanation was that "people can go too far in these cases. If there are to be standards that are nondiscriminatory, this is exactly what they should be. There should not be swept into the question many outside issues, such as whether or not one has been culturally deprived." 124

But Senator Humphrey was not alone. As with the question of racial balance, Senators Clark and Case carefully explained the intended scope of Title VII. For example, Senator Case entered into the Record his own Interpretive Memorandum regarding Title VII and the Motorola case. It is a memorandum that was conveniently ignored by the court in Griggs:

It has been suggested, nevertheless, that the decision by the hearing examiner should be taken as indicative of the kinds of decisions which might be expected to be made by Federal bureaucrats if title VII of the pending civil rights bill were enacted. Of course, this is completely wrong. It would definitely not be possible for a decision like Motorola to be entered by a Federal agency against an employer under title VII. . . . It is perfectly clear that title VII would not permit even a Federal court to rule out the use of

${ }^{124}$ Congressional Record (23 March 1964) 110: 6000. 
particular tests by employers because they do not "equate inequalities and environmental factors among the disadvantaged and culturally deprived groups." . . . It is enough to note that the result seems questionable. There is no doubt, however, that such a result would be unmistakably improper under the proposed Federal law. ...

Whatever its merit as a socially desirably objective, title VII would not require, and no court could read title VII as requiring, an employer to lower or change the occupational qualifications he sets for his employers simply because proportionately fewer Negroes than whites are able to meet them. . . . Title VII says merely that a covered employer cannot refuse to hire someone simply because of his color, that is, because he is a Negro. But it expressly protects the employer's right to insist that any prospective applicant, Negro or white, must meet the applicable job qualifications. Indeed, the very purpose of title VII is to promote hiring on the basis of job qualifications, rather than on the basis of race or color. Title VII would in no way interfere with the right of an employer to fix job qualifications and any citation of the Motorola case to the contrary as precedent for title VII is wholly wrong and misleading. ${ }^{125}$

Another critical piece of evidence is found in the Interpretive Memorandum of

Title VII, which was written specifically to guide the courts in future cases. When discussing the intended use of statistics in discrimination cases, Senators Clark and Case argued that while statistics have some probative value, there is still a threshold requirement of intent:

It must be emphasized that discrimination is prohibited as to any individual. While the presence or absence of other members of the same minority group in the work force may be a relevant factor in determining whether in a given case a decision to hire or to refuse to hire was based on race, color, etc., it is only one factor, and the question in each case would be whether that individual

${ }^{125}$ Congressional Record (26 March 1964) 110: 6416 (emphasis added). This memorandum was reprinted again a few days later; see page 7246. This memorandum was also reprinted and distributed nearly verbatim in the Bipartisan Civil Rights Newsletter No. 16, Congressional Record (9 April 1964) 110: 7479. 
was discriminated against. ${ }^{126}$

Senator Case produced another key witness to bolster his defense of Title VII. Charles Gray was chairman of the Illinois FEPC in 1964, and wrote to the Illinois Chamber of Commerce to clarify several key issues regarding the Motorola case. Although he did not pass judgement on a matter pending before the Commission, he seemed to suggest that he disagreed with the result. Further, he sketched for the Chamber of Commerce several key principles of the FEPC, the first one being the most important:

1. The right of an employer to establish standards of employment, to establish testing and screening devices in employment, and to employ persons of their own choice, is an absolute right as long as the decision is not made on the basis of race, religion, or national origin. ${ }^{127}$

Motorola did not let the charges against itself go unanswered. Senator Tower, who would eventually introduce section 703(h) into the Act, read Motorola's statement into the Record. Motorola pointed out that Myart omitted some pertinent education and work experience on his application. Further, he failed a test given specifically to applicants for the analyzer-phaser job. Motorola required seven correct answers out of ten, yet Myart answered only one question correctly. Motorola also

${ }^{126}$ Congressional Record (8 April 1964) 110: 7213.

${ }^{127}$ Congressional Record (8 April 1964) 110: 7247. Near the end of the debate on testing, Senator Case stated that he felt certain "that no Member of the Senate disagrees with the views of the Senator from Texas (Senator Tower) concerning the Motorola case finding by the referee or examiner; " see Congressional Record (11 June 1964) 110: 13,503. 
checked his references, and one previous employer told Motorola that Myart was "not rehirable." And last, Myart had been convicted of sodomy, and Motorola had a policy of not hiring applicants when there was a question of "moral turpitude."

Motorola took exception to Bryant's entire opinion. In his decision, Bryant cited three texts on psychology, which were not introduced at the hearing and which Motorola had no opportunity to rebut. Motorola contacted the author of the leading book, who told the company that his work was quoted out of context and had been misinterpreted. But most importantly, Motorola went to considerable length to demonstrate that these tests had been professionally developed by psychologists at the Illinois Institute of Technology. ${ }^{128}$ Originally written around 1950, they had been updated three years before Myart failed them. Motorola had hired several IIT professors to do what would today be known as a "validation" study. They concluded that the test was "race free." Furthermore, Motorola had been actively recruiting employees from black colleges since $1961 .{ }^{129}$ Not surprisingly, the company was irked by accusations that it was attempting to discriminate against Myart. Motorola's conclusion:

${ }^{128}$ Several professors from IIT testified on Motorola's behalf. One had experience writing exams for the U.S. Civil Service Commission, which has for years been using screening tests for federal job applicants. On a more humorous note, Motorola's expert witnesses all testified that the tests do discriminate, but only against those who are not trainable for certain jobs; see Congressional Record (11 June 1964) 110: 13,493-503.

${ }^{129}$ Congressional Record (24 April 1964) 110: 9030. 
The profit success of our company depends in great measure upon our ability to effectively select the talents we need to accomplish our tasks. If we are denied this right by the FEPC, then the State usurps the employer's authority and a government agency sets the employment standards by which we and other employers must hire. ${ }^{130}$

Senator Clark was quick to dispute the possibility of another Motorola case

arising under Title VII. His letter to the editors of the Wall Street Journal, reprinted

in the Record, insisted that tests could be invalidated only if they were used with the

intent to discriminate:

The (Act) would not make unlawful the use of tests such as those used in the Motorola case, unless it could be demonstrated that such tests were used for the purpose of discriminating against an individual because of his race, color, religion, sex, or national origin. In other words, it is not enough that the effect of using a particular test is to favor one group above another, to produce a violation of the act; an act of discrimination must be taken with regard to the individual, "because of such individual's race, color, religion, or national origin," to quote from the language of the bill.

The Senate's own FEP bill (a different bill that did not pass) . . . would cover the substance of the Motorola case. The Senate's bill expressly provides that discrimination "shall include any act or practice which, because of an individual's race, color, religion, or national origin, results or tends to result in material disadvantage, or impediment to any individual in obtaining employment or the incidents of employment for which he is otherwise qualified." Unlike title VII of the pending civil rights bill, this language would reach the situation where an ostensibly nondiscriminatory test did in fact place at a disadvantage members of culturally deprived minority groups.

The opponents of the (Act) have had striking success in stirring confusion about what the bill would or would not do, and the Motorola case has been a favorite hobbyhorse. Frankly, I prefer the Senate bill to title VII, and so, I believe, do the 12 members of the Senate Labor and Public Welfare

${ }^{130}$ Congressional Record (24 April 1964) 110: 9025. Senator Tower also entered into the Record the twenty eight questions from test No. 10, and also a newspaper article suggesting that a member of the President's Committee on Equal Opportunity who investigated the case found evidence which supported Motorola's position, but this investigator was unwilling to co-operate with Motorola's lawyers; see page 9033. 
Committee who voted to report it favorably to the floor. I believe that the situation presented in the Motorola case should be covered by Federal law.

But whatever my preferences, and those of my colleagues may be, the fact remains that the issues raised by the Motorola case have nothing to do with title VII of the (Act), and are plainly beyond its scope. ${ }^{131}$

Having hashed through charge and countercharge, Senator Tower finally introduced what would become 703(h). After an initial proposal was defeated, Tower proposed the language that is now found in the statute. Even when Senator Humphrey voted against Tower's first proposed amendment, he told the Senate that "these tests are legal. They do not need to be legalized a second time. They are legal unless used for the purpose of discrimination." 132

\section{Chief Justice Burger concluded with a flourish:}

From the sum of the legislative history relevant in this case, the conclusion is inescapable that the EEOC's construction of @ 703 (h) to require that employment tests be job related comports with congressional intent. ${ }^{133}$

The inescapable conclusion is something entirely different: any "professionally developed ability test" is valid so long as it is not used with the intent to discriminate. The general intelligence tests used in both Griggs and the Motorola case are virtually

${ }^{131}$ Congressional Record (19 June 1964) 110: 14,468. It is critically important to note that Senator Clark personally believed that employment tests that put minorities at an advantage should be prohibited, but Clark conceded quite explicitly that they were not prohibited under Title VII.

${ }^{132}$ Congressional Record (11 June 1964) 110: 13,504; see also Congressional Record (13 June 1964) 110: 13,724 (remarks of Senator Humphrey).

${ }^{133} 401$ U.S. at 436. 
identical. As the plaintiff Griggs never proved that Duke Power imposed these tests with the intent to discriminate, the only logical conclusion is that the tests were legal. To argue otherwise is to ignore both the text and its unambiguous history.

Supporters of the decision often insist that Duke Power's intent to discriminate is simply too obvious to debate. After all, Duke Power had discriminated before 1964, and the tests were imposed the day the 1964 Act took effect. This, however, does not make them illegal. Duke abandoned all discriminatory practices in 1964, and used a merit-based hiring and promotion system explicitly endorsed by Congress. As supporters of the Act stressed endlessly, the Act was designed to remove race from consideration in favor of neutral standards and merit.

The suggestion that intelligence testing was unnecessary for manual laborers at Duke Power also crumbles upon closer inspection. In a day and age in which all industrial worksites are becoming more complicated, it only stands to reason that workers be expected to have some sort of demonstrable competence. For example, one of the questions from the test that Myart failed included the following:

2. When a large fire occurs, the first thing to do is: (1) call the foreman; (2) turn in the alarm; (3) put it out; (4) run. ${ }^{134}$

Motorola's expert psychologists from IIT had suggested that even applicants

${ }^{134}$ Congressional Record (24 April 1964) 110: 9033. The questions as they appear in the Record do not include the answers, but here the correct answer must surely be to pull the fire alarm. 
for low-level janitor positions should be screened with multiple-choice questions. ${ }^{135}$ These tests, by 1963 , were widely used in most of the nation's industries. ${ }^{136}$ Even the EEOC's own Administrative History concedes that Congress intended to protect these types of aptitude tests. ${ }^{137}$ In short, Griggs represents exactly the opposite of what was determined in 1964.

Taken together with the Philadelphia Plan, a pattern begins to emerge. Hugh Graham noted that once the EEOC won the battle in Philadelphia, the EEOC never bothered to "find" discrimination again. Thus, 703(j) was written out of Title VII. In the Griggs case, Nathan Glazer has demonstrated that with this victory in hand, the EEOC has made virtually all forms of professional testing illegal. ${ }^{138}$ Thus, 703(h) has been written out as well. Even though the Constitution states that Congress shall write the laws, the executive branch has deliberately reinterpreted these laws to say something entirely different. In both instances, the courts have given their approval.

${ }^{135}$ Congressional Record (11 June 1964) 110: 13,499. This expert witness offered a hypothetical question with answer: "Why does an electrician wear rubber gloves? To keep his hands warm, things of this sort. The answer, of course, being that rubber is a good insulator."

${ }^{136}$ Note, "Legal Implications of the Use of Standardized Ability Tests in Employment and Education," Columbia Law Review 68 (1968): 705.

${ }^{137}$ Graham, The Civil Rights Era, 251.

${ }^{138}$ Glazer, Affirmative Discrimination: Ethnic Inequality and Public Policy (New York: Basic Books, 1975), 33-76; see also Note, "Developments in the Law," 1131. 


\section{CHAPTER 4}

\section{WEBER}

Brian Weber was a white employee of Kaiser Aluminum \& Chemical Corporation at Gramercy, Louisiana. Acting on his own behalf and of other white employees "similarly situated," he filed suit in 1976 to stop Kaiser's affirmative action plan. These white employees were denied available spots in Kaiser's new inhouse training program for craft workers on the basis of race.

On February 1, 1974, Kaiser and the United Steelworkers of America (USWA) agreed to the "1974 Labor Agreement." Aside from the usual specifications about hours and wages, there was also a clause directed at minority representation in the craft unions. Specifically, Kaiser created its own in-house training position for craft workers, and the 1974 agreement included a "Memorandum of Understanding" to the effect that for every white worker who entered this training program, one black worker would be admitted as well. This program would not cease until the number of black craft workers at Kaiser was 39 percent, which was the percentage of black people in the neighboring community in 1974.

Under normal procedure, people with the most seniority would gain admission to this training program. However, since many blacks at Kaiser did not have sufficient seniority, Kaiser created two different seniority systems. Brian Weber had 
greater seniority than any of the black employees at Kaiser, and would have been

admitted to this program if it were not for the dual seniority system.

Weber $v$ Kaiser Aluminum ${ }^{139}$

The heart of this case was section 703(a), which states that:

(a) It shall be unlawful employment practice for an employer

(1) to fail or refuse to hire or to discharge any individual, or otherwise to discriminate against any individual with respect to his compensation, terms, conditions, or privileges of employment, because of such individual's race, color, religion, sex, or national origin; or

(2) to limit, segregate, or classify his employees or applicants for employment in any way which would deprive or tend to deprive any individual of employment opportunities or otherwise adversely affect his status as an employee, because of such individual's race, color, religion, sex, or national origin. ${ }^{140}$

Also, section $703(d)$ reads as follows:

(d) It shall be an unlawful employment practice for any employer, labor organization, or joint labor-management committee controlling apprenticeship or other training or retraining, including on-the-job training programs to discriminate against any individual because of his race, color, religion, sex, or national origin in admission to, or employment in, any program established to provide apprenticeship or other training. ${ }^{141}$

At the district court trial, it was revealed that for every black person admitted

to this training program, there was at least one white person with more seniority who

${ }^{139} 415$ F. Supp. 761 (E.D. La. 1976).

${ }^{140}$ United States Code 42: 2000e-2(a).

${ }^{141}$ United States Code 42: 2000e-2(d). 
was displaced by this program. ${ }^{142}$ Because of this program, white employees had been segregated or classified in such a way as to deprive them of employment opportunities.

The Gramercy plant had a non-discriminatory policy since the time it opened in 1958. Further, the record stated that prior to 1974 Kaiser had "vigorously" sought black craftsmen from the neighboring community. Even so, Kaiser found it nearly impossible to find qualified blacks. When the 1974 plan was agreed to, only 2.5 percent of Kaiser's well-paid craftsmen were black. Kaiser claimed that this program was designed to raise the percentage of black craftsmen, and that an in-house training program was created in part because of the scarcity of qualified black craftsmen. ${ }^{143}$ Judge Gordon ruled that Kaiser's plan violated Title VII, regardless of its purpose. Rejecting Kaiser's argument, he concluded that he could not ignore "the clear and unequivocal prohibitions" of 703(a) and 703(d). Further, he concluded that Congress meant to ban every type of preference. Congress debated and rejected the idea of affirmative action in $1964,{ }^{144}$ and he could not help but reach any other conclusion:

This Court . . is not sufficiently skilled in the art of sophistry to justify such discrimination by employers in light of the unequivocal prohibitions against racial discrimination against any individual contained in Sections 703(a) and

\footnotetext{
${ }^{142} 415$ F. Supp. at 764.

${ }^{143} 415$ F. Supp. at 764-65.

${ }^{144} 415$ F. Supp. at 766.
} 
(d) of the 1964 Act. $^{145}$

Judge Gordon was correct, and the artistic sophistry would have to wait until the case reached the Supreme Court.

Weber v. Kaiser Aluminum ${ }^{146}$

On appeal, Kaiser tried a different defense. Since the district court ruled that this plan was illegal under Title VII, Kaiser argued that their plan was in response to Executive Order 11,246. The third circuit court of appeals had accepted this argument when confronted with the Philadelphia Plan, but Kaiser found no receptive audience here.

The court split 2-1, with judges Gee and Fay ruling that Kaiser's plan, regardless of Title VII, was "flatly and literally prohibited" by Title VII. ${ }^{147}$ The majority also demonstrated that preferential treatment for the sake of racial balance, and not to correct a past discriminatory practice, has been invalidated by other courts. ${ }^{148}$

${ }^{145} 415$ F. Supp. at 769.

${ }^{146} 563$ F.2d 216 (5th cir. 1977).

${ }^{147563 ~ F .2 d ~ a t ~} 219$.

${ }^{148563 ~ F .2 d ~ a t ~} 221$. It should be noted that the court cited the Contractors' Association decision of 1971 as controlling precedent. As has been argued earlier, the Plan upheld in that case was not based on any demonstrated instance of discrimination. Nonetheless, that case has been interpreted by the federal courts as a remedy imposed for past discrimination, and this understanding allowed the majority here to distinguish Weber's case from the Philadelphia Plan. 
The court's analysis of E.O. 11,246 went right to the heart of affirmative action's ambiguity. Kaiser argued that its plan was based on Revised Order No. 4, which in turn was based on 11,246 . This Order requires "underutilization" studies regarding minority and female representation in the work force. But as judge Gee noted, "the regulation then confuses things mightily by declaring that a goal shall not be considered a device for instituting quotas or reverse discrimination." 149 Given the inherent contradiction between Title VII and 11,246 , the court properly chose Congress' laws over the President's orders. ${ }^{150}$ Further, the court rejected the goals/quotas distinction by noting that attempts to distinguish between the two have been illusory. ${ }^{151}$

The court went to considerable lengths to demonstrate that if Kaiser had, in fact, been found guilty of discrimination, a quota system or something similar could be imposed as an appropriate remedy. But

${ }^{149} 563$ F.2d at 222.

150563 F.2d at 227.

${ }^{151} 563$ F.2d at 222 . The court noted that a key architect of the Philadelphia Plan had later confessed that the Labor Department was, in fact, instituting quotas:

While serving in the Labor Department, I helped devise minority employment goals for government contractors.

I now realize that the distinction we saw between goals and timetables on the one hand, and unconstitutional quotas on the other, was not valid. Our use of numerical standards in pursuit of equal opportunity has led ineluctably to the very quotas, guaranteeing equal results, that we wished to avoid. Silberman, "The Road to Racial Quotas," Wall Street Journal, Aug. 11, 1977, at 12 , column 4; cited at 222 (n. 10). 
In the absence of prior discrimination a racial quota loses its character as an equitable remedy and must be banned as an unlawful racial preference prohibited by Title VII, @ 703(a) and (d). Title VII outlaws preferences for any group, minority or majority, if based on race or other impermissible classifications, but it does not outlaw preferences favoring victims of discrimination. ${ }^{152}$

And as a final matter, the court rejected the idea that Kaiser's plan was designed to correct "societal discrimination." In the court's view, such preferences must be an attempt to correct a proven wrong, or is otherwise "strictly forbidden" by Title VII. ${ }^{153}$

Judge John Minor Wisdom, long regarded as one of the nation's most liberal federal judges, cast the dissenting vote. In his opinion, it was "arguable" that there might be "three possible or probable violations." ${ }^{154}$ Considering how the courts had read Title VII in the past, it is obvious why Wisdom would choose to do this. Such a finding, however flimsy, would allow the court to cast these preferences as remedial in nature. Thus, the court could ignore 703(j), as it did in Contractors' Association. However, not one of Wisdom's "potential" violations has any merit.

Wisdom's first argument was to suggest that Kaiser might have used a "nonvalidated" test. ${ }^{155}$ This was a very curious accusation to make, as Wisdom did

${ }^{152} 562$ F.2d at 224.

${ }^{153} 563$ F.2d at 225.

${ }^{154} 563$ F.2d at 231.

${ }^{155} 563$ F.2d at 231. 
not even offer an allegation that such a test had been given. He only said that it might have somehow happened. Wisdom also argued that the statistics in this case "constituted a prima facie case of discrimination." 156 Much like the Philadelphia Plan upheld in 1971, Wisdom was eager to accept the idea that disproportionate representation was proof of intentional discrimination. Wisdom accused the majority of ignoring this "prima facie" evidence of racial imbalance, yet he himself ignored Kaiser's "vigorous" recruitment of potential black employees. Wisdom's "discrimination" was intentional in only the most tenuous sense.

Second, Wisdom argued that Kaiser's initial requirement that craftsmen have five years' experience might also somehow be illegal. Wisdom conceded that there was evidence demonstrating that experienced craftsmen were cheaper to employ than novices, but insisted that "no effort was made to present contrary evidence." 157 In Wisdom's opinion, Kaiser could not claim that work experience was a business necessity, even though he admitted that it was. He also ignored the unanimous intent of Congress, as discussed earlier, that employers may set their qualifications as high as they like, regardless of any disparate impact, so long as these qualifications were not imposed with the intent to discriminate.

Wisdom's third potential violation was the requirement of any training for certain craft jobs. This was an exceedingly weak argument, and Wisdom conceded

${ }^{156} 563$ F.2d at 231.

${ }^{157} 563$ F.2d at 231-32. 
that it could be "easily refuted" by Kaiser. Indeed, he took all of three sentences to discuss this point. ${ }^{158}$

As a final matter, Wisdom conceded that Kaiser had made "admirable" attempts to recruit black craftsmen, and that they acted in good faith compliance with 11,246 . But he insisted that "good faith . . . is not a defense to Title VII."159 This bald assertion ignores $706(\mathrm{~g})$, which states that there must be proven intentional discrimination before any sort of remedy can be found. Wisdom seemed to hint that a valid defense would be the actual presence of minorities on the payroll, although this would contradict section $703(\mathrm{j})$. Furthermore, Wisdom ignored the explicit language of 713(b):

In any action or proceeding based on any alleged unlawful employment practice, no person shall be subject to any liability or punishment for or on account of (1) the commission by such person of an unlawful employment practice if he pleads and proves that the act or omission complained of was in good faith, in conformity with, and in reliance on any written interpretation or opinion of the Commission. . . . Such a defense, if established, shall be a bar to the action or proceeding, notwithstanding that (A) after such act or omission, such interpretation or opinion is modified or rescinded or is determined by judicial authority to be invalid or of no legal effect. . . ${ }^{160}$

\section{United Steelworkers v. Weber ${ }^{161}$}

The Supreme Court, in what must be one of the most egregious examples of

\footnotetext{
${ }^{158} 563$ F.2d at 232.

${ }^{159} 563$ F.2d at 232.

${ }^{160}$ United States Code 42: 2000e-12(b) (emphasis added).

${ }^{161} 443$ U.S. 193 (1979).
} 
statutory interpretation in recent memory, promptly ruled that Title VII says what it does not say.

Justice Brennan, writing for a 5-2 majority, concluded that Title VII does not prohibit voluntary affirmative action plans. ${ }^{162}$ While conceding that Weber's argument was "not without force," Brennan insisted that Weber's "reliance upon a literal construction of @@ 703(a) and (d) . . . is misplaced." In doing so, Brennan cited a nineteenth century decision which noted that it is a "familiar rule, that a thing may be within the letter of the statute and yet not within the statute, because not within its spirit, nor within the intention of its makers. "163 This assertion is unwarranted.

At oral argument, Kaiser's lawyer was asked whether Kaiser's plan was a "prima facie violation" of Title VII: "It is an evident discrimination against white people, isn't it?" Kaiser's reply: "In the literal sense, it is discrimination."164 Justice Brennan, however, suggested that 703(a) and (d) should instead be read

${ }^{162}$ Justices Powell and Stevens did not participate.

${ }^{163443}$ U.S. at 201; The case cited was Holy Trinity Church v. U.S., 143 U.S. 457,459 (1892).

${ }^{164}$ Transcript of Oral Argument, 12; reproduced in Phillip Kurland and Gerhard Casper, eds., Landmark Briefs and Arguments of the Supreme Court of the United States: Constitutional Law, 1974 Term Supplement (Volume 112: United Steelworkers of America, AFL-CIO-CLC v. Weber, 1979) (Washington, D.C.: University Publications of America, 1978), 877-925. Lawrence Wallace, representing the United States as amicus curie for United Steelworkers, conceded the same thing when asked; see Transcript of Oral Argument, 21. 
against the legislative history of Title VII, so as to avoid reliance on any literal interpretation of what the law said. In other words, reliance on "law office" history would allow the majority to escape from Title VII's unambiguous language.

Brennan cited Senators Humphrey, Clark and Kennedy repeatedly to reach the conclusion that the 1964 Act was an attempt to improve the plight of blacks nationwide. Further, these same Senators had stressed that blacks would generally have no motivation to work when they had no chance for advancement. ${ }^{165}$ This allowed Brennan to frame Weber's claim against the lofty purposes of Titie ViI, while ignoring the text.

Perhaps even more striking, Brennan relied on 703(j) to bolster his claim that voluntary preferences would not be prohibited by the Act. Since 703(j) says that employers shall not be required to grant preference in order to correct any sort of racial imbalance, Brennan inferred that they could voluntarily do so. ${ }^{166}$ Aside from the fact that Brennan was reading 703(j) independently from 703(a) and (d), he was also accepting the fiction of voluntary action which had been rejected by both the district and appellate courts.

Judge Gordon stated in his opinion that the real reasons for agreeing to this program seemed to be compliance with OFCC regulations and a desire to avoid

\footnotetext{
${ }^{165} 443$ U.S. at $202-3$

${ }^{166} 443$ U.S. at 205-6.
} 
"vexatious litigation" by minority employees. ${ }^{167}$ Since the OFCC was requiring Kaiser to institute this program without any finding of discrimination, this openly violated 703(i). ${ }^{168}$ In its brief to the Supreme Court, Weber's lawyers expanded this argument further. Weber's lawyers, relying on facts developed at the district trial, demonstrated that there was no economic reason to institute this training program; it was far cheaper to hire the available craftsmen off the street. Further, Kaiser was paying $\$ 15,000$ to $\$ 20,000$ per trainee per year, and apprenticeship often required two or three years. ${ }^{169}$ Weber's lawyers also demonstrated that the Supreme Court had, on previous occasions, explained the Title VII to demand racial neutrality:

Its terms are not limited to discrimination against members of any particular race. . . .

This conclusion is in accord with uncontradicted legislative history to the effect that Title VII was intended to "cover all white men and white women and all Americans," and create an "obligation not to discriminate

${ }^{167} 415$ F. Supp. at 765; Section 713(b) grants immunity to employers acting in "good faith" to comply with EEOC guidelines. Thus, Kaiser's lawyers tried to shield themselves from lawsuits brought by whites by claiming immunity. Weber's lawyers argued that these guidelines would protect an employer who discriminated against whites; see Brief for Respondents in Opposition, 24-25, reprinted in Kurland and Casper, Landmark Briefs, 112: 23-55. Considering the court's final resolution of this case, the point was moot.

${ }^{168}$ The fifth circuit opinion did not quarrel with Gordon's speculations; even Judge Wisdom conceded that Kaiser was under OFCC pressure to hire more blacks; see 563 F.2d at 218-19, 228.

${ }^{169}$ Brief for Respondent, 17; Reproduced in Kurland and Casper, Landmark Briefs 112: $161-260$. 
against whites. ${ }^{170}$

Even the Griggs opinion, though flawed in its reading of 703(h), insisted that

"discriminatory preference for any group, minority or majority, is precisely and only what Congress has proscribed. "171

Congress in 1963 predicted the real reason for Kaiser's implementation of a "voluntary" training program. In the House Judiciary committee report, several dissenting committee members insisted that under Title VII, the EEOC would do exactly what it was doing to Kaiser Aluminum:

By threat of contract cancellation and blacklisting, contractors could be forced to actively recruit employees of a specified race and upgrade them into skilled classifications, although this would displace union members in the skilled trades. Where skilled tradesmen of the specified race were not available from union sources, the agency could direct that they be recruited from nonunion sources, notwithstanding existing union shop or exclusive referral agreements. ${ }^{172}$

Kaiser was not a primary contractor, but since they provided steel and aluminum to primary contractors, they knew that all subcontractors would be required

${ }^{170}$ Brief for Respondent, 35 (citing McDonald v. Santa Fe Trail Transportation Co. 427 U.S. 273, 278-80; footnotes omitted); The McDonald court ruled explicitly that the standards of Title VII apply alike to whites and blacks, at least in the matter at hand. United Steelworkers, however, pointed out that the McDonald court emphasized that it was not then passing on the legality of affirmative action programs; see Brief for Petitioner, United Steelworkers of America, AFL-CIO-CLC, 23; reproduced in Kurland and Casper, Landmark Briefs 112: 74-159.

${ }^{171}$ Brief for Respondent, 36; see also pages 37-41.

${ }^{172}$ Congress, House of Representatives, Committee on the Judiciary, Civil RightsThe President's Program, 1963, 88th Congress, 1st session, 20 November 1963, 72 (1963). 
to comply or face blacklisting by the EEOC. As one critic has noted, the risk of informal blacklisting by the EEOC is enough to bankrupt companies and universities that rely heavily on federal money. ${ }^{173}$ And since $703(\mathrm{j})$ prohibits the EEOC from forcing racial balance on contractors, they must create an appearance of voluntary action or risk retaliation from what one opponent in 1964 speculated would be arrogant behavior by "enthusiastic" regulators. ${ }^{174}$ And yet, despite all this, Justice Brennan cited Senator Miller's insistence that federal bureaucrats would not interfere with private businesses "because of some Federal employee's ideas about racial balance or racial imbalance. 175

${ }^{173}$ Sherain, "The Questionable Legality of Affirmative Action," 40-41; see also Edmund Kitch, "The Return of Color-Consciousness to the Constitution: Weber, Dayton, and Columbus," Supreme Court Review (1979): 3; Judge MacKinnon, dissenting in $A F L-C I O$ v. Kahn (1979):

No amount of sophisticated or metaphysical argument can convince me that compliance under threat of such massive economic sanctions is voluntary.

Cited by Bernard Meltzer, "The Weber Case: The Judicial Abrogation of the Antidiscrimination Standard in Employment," Chicago Law Review 47 (1980): 465 (n. 197).

${ }^{174}$ Congressional Record (20 April 1964) 110: 8500 (remarks of Senator Smathers). Graham notes that the first manning tables were offered by a NASA contractor after considerable coaching by the OFCC; see Graham, The Civil Rights Era, 287.

${ }^{175}$ Congressional Record (18 June 1964) 110: 14,314; cited at 443 U.S. 207. Justice Blackmun, though concurring in the result, noted that Kaiser agreed to this program only after "critical review" by the OFCC regarding compliance with Executive Order 11,246. Although Blackmun did not speculate about the significance of this, it seems fair to guess that Kaiser was not meeting its "goals" and "timetables." 443 U.S. at 210 . Justice Brennan ignored all of this in his majority 
Near the end of his opinion, Brennan stated that the validity of voluntary programs did not depend on the threat of liability under Title VII. ${ }^{176}$ This is an implausible reading of the Act. A minority suing under Title VII can ask the EEOC to intervene on its behaif, and an employer can insulate himself by hiring enough minorities to satisfy the government. As Senator Tower noted, Title VII contains a heavy element of compulsion, which strains the very idea of "voluntary action." 177

In conclusion, Brennan committed two final errors. He argued that Kaiser's plan "does not unnecessarily trammel the interests of the white employees." 178 This was small consolation to Brian Weber and other similarly situated whites, who had been denied promotions on the basis of race. And even more bizarre, Brennan stated that the plan was temporary, and "is not intended to maintain racial balance, but simply to eliminate a manifest racial imbalance. "179 This conveniently ignored Weber's brief to the court, which quoted Kaiser's plant manager as stating that Kaiser was planning to maintain the racial balance in perpetuity. ${ }^{180}$

Chief Justice Warren Burger was not at all amused. While stating that he

opinion.

${ }^{176} 443$ U.S. at 208 (n. 8).

${ }^{177}$ Congressional Record (13 April 1964) 110: 7778.

${ }^{178} 443$ U.S. at 208.

${ }^{179} 443$ U.S. at 208.

${ }^{180}$ Brief for Respondents, 4. 
might vote to uphold an amendment tolerating voluntary preferences if he were a member of Congress, he rejected the idea that the court could write such a thing into Title VII:

I cannot join the Court's judgment, however, because it is contrary to the explicit language of the statute and arrived at by means wholly incompatible with long-established principles of separation of powers. Under the guise of statutory "construction," the Court effectively rewrites Title VII to achieve what it regards as a desirable result. It "amends" the statute to do precisely what both its sponsors and its opponents agreed the statute was not intended to do. ${ }^{181}$

As Burger noted, Title VII was written with "extraordinary clarity." Often the court has had difficulty interpreting "imprecise drafting" or "genuine ambiguities," but here there was no ambiguity. Even more peculiar, the court was using the "very clarity" of 703(j) "as a justification for evading the unavoidable impact of its language." In Burger's opinion, it was "specious" for the court to imply that 703(j) contains some sort of "negative pregnant" authorizing what 703(a) and (d) "unambiguously and unequivocally prohibit."182 In Burger's opinion, the court was exceeding the limits of its authority to rewrite a "crucial part of Title VII" in order to reach a "desirable" result. The opinion was "intellectually dishonest" and an example of using "improper judicial means" to reach a predetermined end. ${ }^{183}$

Alfred Kelly observed in 1965 that the "law office" history requires

\footnotetext{
${ }^{181} 443$ U.S. at 216.

${ }^{182} 443$ U.S. at 217.

${ }^{183} 443$ U.S. at 219.
} 
"counterhistory" in order to be successfully refuted. ${ }^{184}$ Given the exhaustive debate which produced Title VII, few people would be willing to do such a thing. Unfortunately for Brennan, Justice Rehnquist was equal to the challenge. In a now legendary dissent, Justice Rehnquist canvassed the entire congressional history of sections 703 (j), (a), and (d). The force of his dissent has made the Weber decision one of the most controversial decisions of the last twenty years.

In Rehnquist's opinion, Title VII was designed to "prohibit discrimination in employment simpliciter." 185 And as Rehnquist pointed out, Brennan flatly ignored statements in previous cases "patently inconsistent" with the interpretation now reached. ${ }^{186}$ He then turned to Brennan and his law-office history.

Rehnquist began by demonstrating how selectively Brennan was reading the relevant history. For example, Brennan relied heavily on a citation from the House Judiciary committee Report:

No bill can or should lay claim to eliminating all of the causes and consequences of racial and other types of discrimination against minorities. There is reason to believe, however, that national leadership provided by the enactment of Federal legislation dealing with the most troublesome problems will create an atmosphere conducive to voluntary or local resolution of other

${ }^{184} \mathrm{Kelly}$, "Clio and the Court," 132.

${ }^{185} 443$ U.S. at 220 . Rehnquist also rejected the idea that voluntary preferences are a good idea. In his opinion, "two wrongs do not make a right." See 443 U.S. at 228 (n. 10).

${ }^{186} 443$ U.S. at 221 (n. 1). 
forms of discrimination. ${ }^{187}$

Aside from the fact that this says nothing about specific textual interpretation of Title VII, Rehnquist noted that Brennan conveniently ignored the material immediately following this citation, which suggested that the committee was referring to patterns of discrimination in voting and public accommodation, along with employment. ${ }^{188}$ In other words, Brennan's citation had little to do with 703(j).

Beginning with that same committee report, Rehnquist began by reviewing the fears of the Act's critics. In their opinion, the absence of "racial imbalance" from Title VII was a "public relations" ruse, since the EEOC planned to use "its own construction of 'discrimination' as including the lack of racial balance . . ."189 Further, these critics included a hypothetical situation which Rehnquist felt was of "particular relevance:"

Under the power granted in this bill, if a carpenters' hiring hall, say, had 20 men awaiting call, the first 10 in seniority being white carpenters, the union could be forced to pass them over in favor of carpenters beneath them in seniority but of the stipulated race. And if the union roster did not contain the names of the carpenters of the race needed to 'racially balance' the job, the union agent must, then, go into the street and recruit members of the stipulated race in sufficient number to comply with Federal orders, else his local could

${ }^{187}$ Congress, House of Representatives, Committee on the Judiciary, Civil RightsThe President's Program, 1963, 88th Congress, 1st session, 20 November 1963, 18 (1963); cited by Brennan at 443 U.S. 203-4.

${ }^{188} 443$ U.S. at 229 (n. 11).

${ }^{189}$ Congress, House of Representatives, Committee on the Judiciary, Civil RightsThe President's Program, 1963, 88th Congress, 1st session, 20 November 1963, 6768 (1963); cited by Rehnquist at 443 U.S. 231. 
be held in violation of Federal law. ${ }^{190}$

Congressman Celler, in the first major speech defending the Act, took pains to counter what he felt was serious misrepresentation and distortion by the critics. Celler insisted that no "Federal inspector" would order the hiring or promotion of certain minorities. The EEOC's powers would extend only to prohibiting "actual discrimination. "191

Many other supporters made similar arguments. Congressman Lindsay, for example, insisted that Title VII does not "force acceptance of people in . . . jobs . . . because they are Negro." In his opinion, the Act did not create any quotas or "special privileges." "What the bill does do is prohibit discrimination because of race. ${ }^{192}$

Representative Minish added that hiring under Title VII will be based on "merit, not of race." ${ }^{193}$ Representative Goodell offered his prophetic comments:

There is nothing here as a matter of legislative history that would require

${ }^{190}$ Congress, House of Representatives, Committee on the Judiciary, Civil RightsThe President's Program, 1963, 88th Congress, 1st session, 20 November 1963, 71 (1963); cited by Rehnquist at 443 U.S. 232 (n. 12). These critics noted "That this is, in fact, a not too subtle system of racism-in-reverse cannot be successfully denied."

${ }^{191}$ Congressional Record (31 January 1964) 110: 1518; cited by Rehnquist at 443 U.S. 233.

${ }^{192}$ Congressional Record (31 January 1964) 110: 1540; cited by Rehnquist at 443 U.S. 233 (n. 13).

${ }^{193}$ Congressional Record (1 February 1964) 110: 1600; cited by Rehnquist at 443 U.S. 233. 
racial balancing. . . . We are not talking about a union having to balance its membership or an employer having to balance the number of employees. There is no quota involved. It is a matter of an individual's rights having been violated, charges having been brought, investigation carried out and conciliation having been attempted and then proof in court that there was discrimination and denial of rights on the basis of race or color. ${ }^{194}$

House Republicans further insisted that Title VII "does not permit the ordering of racial quotas in businesses or unions and does not permit interferences with seniority rights of employees or union members. "195

Having passed the House, the bill was then sent to the Senate, where it was subjected to the longest filibuster in history. Virtually every important section of Title VII was debated endlessly. And while the focus was on employers being forced to grant preferential treatment, Justice Rehnquist uncovered key material in the legislative record which stated that employers could not voluntary prefer minorities, either:

Employers and labor organizations could not discriminate in favor of or against a person because of his race, his religion, or his national origin. In such matters . . . the bill now before us . . . is color-blind." 196

Rehnquist soon returned to the Interpretive Memorandum of Senators Clark and Case. As they were the Senate captains of Title VII, it was their responsibility to

${ }^{194}$ Congressional Record (8 February 1964) 110: 2558; cited by Rehnquist at 443 U.S. 233.

${ }^{195}$ Congressional Record (30 March 1964) 110: 6566; cited by Rehnquist at 443 U.S. 233.

${ }^{196}$ Congressional Record (30 March 1964) 110: 6564 (remarks of Senator Kuchel); cited by Rehnquist at 443 U.S. 238. 
clarify every section of Title VII. As for the employment of minorities, their memorandum states that any deliberate attempt to maintain a racial balance would require an employer to hire or fire on the basis of race. Clark and Case stated that employers would not be allowed to voluntarily prefer minorities over whites, and that Title VII would not effect the seniority of white workers. This applied even if the company had previously been all-white, which Kaiser had not. ${ }^{197}$

As for Brennan's extensive reliance on Senator Humphrey's comments,

Rehnquist demonstrated conclusively that Brennan's analysis was highly selective:

The title does not provide that any preferential treatment in employment shall be given to Negroes or to any other persons or groups. It does not provide that any quota systems may be established to maintain racial balance in employment. In fact, the title would prohibit preferential treatment for any particular group, and any person, whether or not a member of any. minority group, would be permitted to file a complaint of discriminatory employment practices. ${ }^{198}$

Rehnquist noted in his review of the material that during the 83 days in which Title VII was debated, not one Senator suggested that employers could voluntarily prefer minorities over whites. ${ }^{199}$ He did, however, note that critics of the Act

${ }^{197}$ Congressional Record (8 April 1964) 110: 7213; cited by Rehnquist at 443 U.S. 239-40. Other material, explicitly endorsing this interpretation, is found on page 7207 of the Record.

This memorandum was previously reviewed in the discussion of the Philadelphia Plan. However, given its relevance to Brian Weber's case, it is worthwhile to briefly mention this material again.

${ }^{198}$ Congressional Record (25 May 1964) 110: 11,848 (remarks of Senator Humphrey); cited by Rehnquist at 443 U.S. 243.

${ }^{199} 443$ U.S. at 244. 
complained that under Title VII, black entrepreneurs could not prefer blacks in an attempt to help improve the lot of their own race. ${ }^{200}$ Given an entire century of discrimination, it seems difficult to believe that the EEOC would be eager to pounce on a black employer who did this. Nonetheless, these Senators were correct in their interpretation of Title VII. And further, this was emphasized by Senator Muskie as passage of the Act drew closer:

All the torrent of words, all the legalistic arguments, all the appeals the Constitution cannot obscure this basic, simple truth: Every American citizen has the right to equal treatment-not favored treatment, not complete individual equality-just equal treatment. . . . Title VII seeks to afford to all Americans equal opportunity in employment without discrimination. Not equal pay. Not "racial balance." Only equal opportunity. ${ }^{201}$

This, however, was not the real clincher of Justice Rehnquist's dissent.

Brennan suggested from deduction that 703(j)'s rejection of forced preferences implies tolerance of voluntary ones, yet Rehnquist demonstrated that Congress knew how to exempt voluntary preferences if it had wanted to do so. Congress had preserved a traditional preference for Native Americans in section 703(i):

Nothing contained in [Title VII] shall apply to any business or enterprise on or near an Indian reservation with respect to any publicly announced employment practice of such business or enterprise under which a preferential treatment is given to any individual because he is an Indian living on or near a

${ }^{200} 443$ U.S. at 250 (n. 29).

${ }^{201}$ Congressional Record (3 June 1964) 110: 12,614, 12,617; quoted by Rehnquist at 443 U.S. 247-48. See also the remarks of Senator Saltonstall, at (4 June 1964) 12,691: Title VII "provides no preferential treatment for any group of citizens. In fact, it specifically prohibits such treatment." 
reservation. $^{202}$

Justice Rehnquist was thorough in his analysis of the Congressional Record, and in his dissection of Justice Brennan's opinion. Even so, Rehnquist missed a key piece of evidence that struck at the very heart of the Weber decision.

In 1963, before the death of President Kennedy, Illinois Representative Robert McLoskey inserted a statement into the Record. Under the title of "Labor Beware," Congressman McLoskey predicted what happened in this case:

Integration, under the Civil Rights Act of 1963 will no longer be enough. The word, today, is "balance." Unless there is an arithmetically balanced racial and religious mix, under this bill, even integrated unions that heretofore have prided themselves on their tolerance would be in violation of this statute as certainly as all-white unions. For, under this bill, every local must attain racial and religious balance at all levels and in all categories, and if this means seniority rules would have to be ignored to obtain the proper mix, then they would have to be ignored. Needless to say, everything that applies to unions applies equally to their apprenticeship training programs. . . .

Under the bill, then, it will not be enough to hire qualified union members as they present themselves, in order, one-by-one, at the hiring hall. If the local finds it cannot balance, racially and religiously, the skilled craftsmen needed, the hiring hall must actively recruit-go out and get-such craftsmen as "balance" may demand, even though paid-up union members of another race sit without work. Such is the sense of this section. . . .

Under this act, Mr. Speaker, it seems clear, then, the union movement's time-honored system of seniority will be destroyed. . . .

Under (Title VII) the seniority system would be destroyed. ${ }^{203}$

${ }^{202}$ United States Code 42: 2000e-2(i).

${ }^{203}$ Congressional Record (25 September 1963) 109: 18,133 (emphasis added). 
In his majority opinion, Justice Brennan stated that "given this legislative history, we cannot agree with respondent that Congress intended to prohibit the private sector from taking effective steps to accomplish the goal that Congress designed Title VII to achieve. "204 In this sense, Brennan was entirely correct. Given his superficial and selective reading of the Congressional Record, Brennan could reach the conclusion that he did. Unfortunately, what Brennan wrote cannot seriously be considered an attempt at "history."

Justice Rehnquist concluded his dissent by noting that "one is led inescapably to the conclusion that Congress fully understood what it was saying and meant precisely what it said:"205

Finding the desired result hopelessly foreclosed by these conventional sources, the Court turns to a third source -- the "spirit" of the Act. But close examination of what the Court proffers as the spirit of the Act reveals it as the spirit animating the present majority, not the 88th Congress. ${ }^{206}$

Considering that the evidence was overwhelmingly in Rehnquist's favor, it seems that he had the stronger argument. In retrospect, it is hard to believe even Justice Brennan truly believed his interpretation of Title VII was faithful to its text or history.

Some have tried to defend the Weber decision as consistent with the concept of
${ }^{204} 443$ U.S. at 204.
${ }^{205} 443$ U.S. at 252.
206443 U.S. at 254. 
"justice," but as Felix Frankfurter noted some years ago, "the Court is not saved from being oligarchic because it professes to act in the service of humane ends. "207 As Professor Meltzer has noted, the Weber decision raises troubling questions about the competency and integrity of the court. ${ }^{208}$ Or perhaps, as Justice Rehnquist argued, the court was simply sowing the wind.

${ }^{207}$ A.F. of L. v. American Sash \& Door Co., 335 U.S. 538, 5.55-56 (1949); cited by Kelly, "Clio and the Court," at 130 (n. 43).

${ }^{208}$ Meltzer, "The Weber Case," 457-58. 


\section{CHAPTER 5}

\section{BAKKE}

Alan Bakke was a white male who wanted to go to medical schcol. His quest for admission to U.C. Davis made him a household name, and his case one of the most controversial ever.

Bakke graduated the University of Minnesota with a degree in mechanical engineering, then went to Stanford for his M.A. He was an NROTC at Minnesota, and later served as a Marine captain in Vietnam. Upon completion of his degree at Stanford, he went to work for NASA in Palo Alto.

Though he had been trained as an engineer, Bakke's real ambition was to be a doctor. Since he did not have the necessary courses, he took a full-time load of the required sciences (biology, chemistry, etc.), while also working his full-time job. In his off hours, he worked as an emergency room volunteer. All this was done while still meeting his obligations to his wife and three children.

In 1973 he applied to a dozen medical schools, but was rejected by every one. Bakke was particularly incensed at his be rejection by U.C. Davis, which had reserved 16 of the 100 spaces in its incoming class for selected minority applicants. Bakke's grades and test scores were much higher than those admitted to the program, to say nothing of his recommendations and experience. Bakke filed suit, claiming 
that he had been discriminated against on the basis of race. He argued that U.C.

Davis' policy violated the Equal Protection Clause of the Fourteenth Amendment, and also Title VI of the Civil Rights Act of $1964 . .^{209}$

This issue, however, was not new to the courts. Before looking into Bakke's claim, it would be useful to look at the plight of Marco DeFunis, who made a similar claim against the admissions committee at the University of Washington School of Law.

DeFunis, like Bakke, was a white male who had been rejected twice by a state graduate school. He sued, claiming that he was passed over in favor of less qualified minorities. The district court in Washington state upheld his Fourteenth Amendment claim, but the Washington Supreme Court reversed. ${ }^{210}$

Writing for the court, Judge Neill equated Washington's affirmative action program with the Supreme Court's rulings on desegregation. In doing so, he referred specifically to the "continued effects of past segregation," the need for "reasonable

${ }^{209}$ J. Harvie Wilkinson III, From Brown to Bakke: The Supreme Court and School Integration, 1954-1978 (New York: Oxford University Press, 1981), 253-55; Bakke's brief in the Yolo County Superior Court is reproduced in Alfred Slocum, ed., Allan Bakke v. Regents of the University of California: Yolo County, California; Superior Court; California State Supreme Court (Dobbs Ferry, N.Y.: Oceana Publications, 1978), volume I: 3-6.

${ }^{210}$ DeFunis v. Odegaard, 82 Wash. 2d 11 (1973). 
representation," and the "historically suppressed" status of minorities. ${ }^{211}$ In his opinion, the past required (or at least, allowed) the University of Washington to be actively color-conscious, even though there was no previous history of discrimination at Washington. ${ }^{212}$ Judge Neill did not address DeFunis' claim under Title VI.

Judge Neill's opinion did not go unanswered. Even though DeFunis had lost 7-2 before the court, Chief Judge Hale wrote an angry dissent that sharply criticized Neill's entire decision.

The Washington Law School had cut-off points for both admission and rejection. That is, an applicant's GPA and LSAT scores were combined in a fixed ratio, and any score above 77 was usually admitted, while anything below 74.5 was usually rejected. ${ }^{213}$ While the admissions committee was not excessively rigid in applying this formula, Hale demonstrated that most of the minority applicants admitted to Washington had scores so low that they would have been rejected out-ofhand. ${ }^{214}$

Hale also rejected Neill's parallel between affirmative action and

${ }^{211} 82$ Wash. $2 \mathrm{~d}$ at 19-20.

${ }^{212} 82$ Wash. 2d at 27-35; It should be noted that the "desegregation" decisions relied upon by Judge Neill have been sharply criticized for emphasizing "integration" as a form of desegregation. See generally Wilkinson, From Brown to Bakke; Lino Graglia, Disaster by Decree: The Supreme Court Decisions on Race and the Schools (Ithaca, N.Y.: Cornell University Press, 1976).

${ }^{213}$ DeFunis' score was 76.23 .

${ }^{214} 82$ Wash. 2d at 60. 
desegregation. Busing black children into white neighborhoods, or vice versa, did not deny either child of an education. ${ }^{215}$ Hale concluded by citing a similar case filed in California:

Preferential treatment under the guise of "affirmative action" is the imposition of one form of racial discrimination in place of another. The questions that must be asked in this regard are: must an individual sacrifice his right to be judged on his own merit by accepting discrimination based solely on the color of his skin? How can we achieve the goal of equal opportunity for all if, in the process, we deny equal opportunity to some?

Like the majority opinion, Chief Judge Hale did not address the Title VI issue.

DeFunis appealed to the U.S. Supreme Court. In the meantime, DeFunis had been allowed to enroll at the University of Washington School of Law, as the trial court had originally ordered. By the time the case had been scheduled for oral argument, DeFunis had already enrolled for his final quarter. At oral argument, Washington's lawyers stated that DeFunis was making acceptable progress, and that he would graduate on schedule. Even if something unexpected should happen, his readmission to the law school would have been virtually automatic. ${ }^{217}$ The Supreme

${ }^{215} 82$ Wash. 2d at 64.

${ }^{216}$ Anderson v. San Francisco Unified School Dist., 357 F. Supp. 248 (N.D. Cal. 1972); cited at 82 Wash. $2 \mathrm{~d} 67$.

${ }^{217}$ Transcript of Oral Argument, 513, as reprinted in Phillip Kurland and Gerhard Casper, eds., Landmark Briefs and Arguments of the Supreme Court of the United States: Constitutional Law, 1974 Term Supplement (Volume 80: DeFunis v. Odegaard, 1974) (Arlington, V.A.: University Publications of America, 1974). The Transcript is reprinted at pages 499-531; pagination from the bound volume is used, as the transcript itself is not paginated. 
Court dismissed the case as moot. ${ }^{218}$

Only Justice Douglas addressed the merits of DeFunis' claim. In a lengthy and somewhat rambling dissent, Douglas concluded that racial preferences were unconstitutional. In his opinion, DeFunis had a "constitutional right to have his application considered on its individual merits in a racially neutral manner. "219 $\mathrm{He}$ concluded with some stirring language:

The Equal Protection Clause commands the elimination of racial barriers, not their creation in order to satisfy our theory as to how society ought to be organized. . . . If discrimination based on race is constitutionally permissible when those who hold the reins can come up with "compelling" reasons to justify it, then constitutional guarantees acquire an accordionlike quality. . . . So far as race is concerned, any state-sponsored preference to one race over another in that competition (professional schools) is in my view "invidious" and violated of the Equal Protection clause. 220

Neither Justice Douglas, nor any other member of the Supreme Court, discussed DeFunis' Title VI claim.

There was no formal trial in the Bakke case. The factual record consisted entirely of the deposition of Dr. George Lowrey, who was chairman of the admissions committee when Bakke was an applicant. His deposition offers some interesting insights into the admissions process.

${ }^{218}$ DeFunis v. Odegaard, 416 U.S. 312, 318 (1974).

${ }^{219} 416$ U.S. at 337.

${ }^{220} 416$ U.S. at $342-44$. 
Reynold Colvin, Bakke's lawyer, began by questioning Lowrey about the parameters of U.C. Davis' admissions policy. When asked if there were any minimum set standards for the normal admissions process, Lowrey stated that the committee would not accept an applicant with a GPA below 2.5.21 Further, Lowrey stated that while there was no automatic cut-off for MCAT scores, the committee "would look very hard at other things that would be very positive for that individual if he scored lower than 50 in science and verbal ability."222

Colvin soon turned to U.C. Davis' special admissions program. Lowrey testified that this program allowed an applicant to designate himself as "an underprivileged individual in terms of economic, educational disadvantage." 223 These applicants were segregated from the rest, and subject to a modified admissions procedure by a special Task Force. These applicants did not compete against the entire applicant pool, but rather for the sixteen spots designated by the school.

As Colvin began to question Lowrey about these applicants, Lowrey insisted that the emphasis was on socioeconomic disadvantage, and not ethnicity. ${ }^{224}$ Even though several hundred white students had applied as "disadvantaged," not one had

${ }^{221}$ Deposition of George H. Lowrey, M.D., 36; Dr. Lowrey's deposition is reprinted in Slocum, ed., Bakke v. Regents, I: 29-77. The pagination from Slocum's volume is used, as the Deposition itself is not paginated.

${ }^{222}$ Lowrey Deposition, 38.

${ }^{223}$ Lowrey Deposition, 46.

${ }^{224}$ Lowrey Deposition, 55. 
been admitted. ${ }^{225}$ Colvin, however, turned to the GPA's and MCAT scores of students admitted by the Task Force.

Dr. Lowrey's testimony regarding the applicant pool was startling. While students admitted through the normal procedure had an average science GPA of 3.51, those students admitted as "disadvantaged" averaged 2.62. Even more disturbing, the range was 2.11 to 2.93. As Colvin pointed out, some of these students had averages below 2.5 , which means they would have normally been rejected out-of-hand. ${ }^{226}$ Further, given the incredibly competitive nature of medical school admissions, it would seem hard to believe that any applicant would have been admitted under the normal procedure with an SGPA of 2.93.

The MCAT scores of the students admitted by the Task Force were as poor as their GPA's. For normal students, the verbal average was the 81st percentile, versus 46th for the Task Force students. Quantitative scores (i.e. math) were 76 vs. 24, general information was 69 vs. 33, and science was 83 vs. $35 .{ }^{227}$ All this forcibly recalled Lowrey's earlier statement that the admissions committee would be hard-

${ }^{225}$ Exhibit C, 156-58. This exhibit, which is marked "confidential" in large letters, is an internal memorandum of the U.C. Davis admissions office. The memorandum is reproduced in Slocum, ed., Bakke v. Regents, I: 154-63. The pagination from Slocum's volume is used, as the memorandum itself is not paginated.

${ }^{226}$ Lowrey Deposition, 60. On page 63, Lowrey stated that the average SGPA of Task Force applicants for the previous year had been 2.42 , which meant that the average score was lower than the automatic rejection score.

${ }^{227}$ Lowrey Deposition, 60-61. The difference in MCAT scores for the previous year was even worse; see Lowrey Deposition, 63. 
pressed to admit anyone with MCAT verbal and science scores below the 50th percentile. ${ }^{228}$ Further, three of Bakke's four MCAT scores were exceptionally high: 96th percentile in verbal, 94th in math, 97th in science, and 72nd in general information. His SGPA was 3.45 as an undergraduate. ${ }^{229}$

In discussing the manner in which the committee made its final decisions, Dr. Lowrey noted that U.C. Davis did not rely upon any formal, rigid formula, but rather tried to incorporate intangible factors into its decisions. For example, the committee considered what sort of medicine an applicant wanted to practice, and what sort of obstacles an applicant had to face. While stating that race was, in fact, used by the admissions committee, Lowrey insisted that it was only one factor among many. ${ }^{230}$

Judge F. Leslie Manker was not impressed. In his Notice of Intended Decision, Judge Manker noted that no white person was admitted to this program, even though many had applied. ${ }^{231}$ In his opinion, the special admissions program

${ }^{228}$ The Bakke case has been criticized by some for being argued on an inadequate factual record. Colvin's questioning of Lowrey on this point must be taken as an example. Colvin never pressed Lowrey about his previous statement regarding minimum grades and scores. Further, Colvin never asked for a racial breakdown of the average grades and scores of students applying for disadvantaged status, and this information does not appear anywhere in the exhibits.

${ }^{229}$ Lowrey Deposition, 74-75; It is important to note that the record does not make clear whether Bakke's SGPA was based on his engineering classes at Minnesota, or upon the pre-med science courses he later took after graduation.

${ }^{230}$ Lowrey Deposition, 77.

${ }^{231}$ Notice of Intended Decision, 174-75. This Notice is reprinted in Slocum, ed., Bakke v. Regents, I: 165-191. The pagination from the volume is used, as the Notice 
was a sham, designed to conceal U.C. Davis' true motives:

It seems to the Court that this program must be judged upon the basis of how it is carried out not by what defendants may claim it to be. The University announcement of this program does not indicate that it is limited to minority groups and in fact counsel for defendant in his oral argument and in his brief has insisted that it is not exclusively a minority program but that it is one in which minority status is simply considered as one factor in determining a disadvantaged status.

Based upon the evidence in this case the Court finds that this special program of admissions as it existed at the time of the consideration of (Bakke's) two applications. . . . is in fact a program open to and available only to members of racial minority groups and that it excludes consideration of applicants who are members of the white race. It appears to this Court that it logically follows that such program discriminates in favor of minority racial groups and against the white race. ${ }^{232}$

Although Judge Manker ruled against U.C. Davis, he also rejected Bakke's bid for admission. The problem for Bakke was that he did not prove that he would have been admitted to U.C. Davis in the absence of this program. ${ }^{233}$ Bakke's file was strong, but it was not strong enough. ${ }^{234}$

The U.C. Regents promptly appealed.

itself is not paginated.

${ }^{232}$ Notice of Intended Decision, 176.

${ }^{233}$ Notice of Intended Decision, 191.

${ }^{234} J u d g e$ Manker's ruling skirted the argument that Bakke would have been admitted if he had been black. Although Manker's opinion did not mention this argument, it seems obvious why any judge would want to avoid it. Had the court ruled this way, anyone with credentials higher than those admitted through the special admissions program could sue for admission, and the courts would be overwhelmed. 
Bakke vs. Regents of U.C. ${ }^{235}$

Before the state Supreme Court, the Regents took a different tact. Gone was any pretense that the special admissions program was available to "disadvantaged whites;" instead, the Regents focused on acceptable justifications for preferential treatment. The district court concluded that there was no "compelling or even legitimate public purpose to be served in granting preference to minority students in admission ... when to do so denies white persons an equal opportunity for admittance." 236

In its opening brief to the court, U.C. Davis ignored Dr. Lowrey's insistence that special admissions were focused on condition, and not ethnicity. Instead, they focused heavily on the need for minority physicians. ${ }^{237}$ Furthermore, U.C. Davis insisted that its efforts were comparable to desegregation decisions, even though the district court had rejected this argument. ${ }^{238}$ They also insisted that their program did not violate Title VI. ${ }^{239}$ Finally, they insisted that all special admissions

${ }^{235} 18$ Cal. 3d 34, 553 P. 2d 1152 (1976); Bakke's case was originally scheduled to be heard by the California appellate courts, but was transferred to the California Supreme Court because of the importance of the issues involved; see Petition for Transfer, reprinted in Slocum, ed., Bakke v. Regents, I: 215-21.

${ }^{236}$ Notice of Intended Decision, 190.

${ }^{237}$ Opening Brief of Appellant and Cross-Respondent, 14-15, 26-28; Reprinted in Slocum, ed., Bakke v. Regents, I: 227-70. (hereafter, "Regent's CA Brief")

${ }^{238}$ Regent's CA Brief, 22-25.

${ }^{239}$ Regent's CA Brief, 34-35. 
minorities were "educationally and economically disadvantaged," which would allow them to be judged on a different standard. ${ }^{240}$

Donald Reidhaar, attorney for the Regents, had a difficult time selling his argument to the California Supreme Court. Reidhaar had just began opening his defense when the justices peppered him with questions about the 2.5 GPA cut-off for regular applicants, and why it was not applied to special admissions cases. ${ }^{241}$ Further, Reidhaar confessed that in practice, no disadvantaged whites were admitted through this program. ${ }^{242}$

Having thus conceded that the program was for minorities only, Reidhaar argued that there were valid reasons for this. Aside from the need for balance, Reidhaar argued that minorities were more likely than whites to practice in minority neighborhoods that are short on doctors:

CHIEF JUSTICE WRIGHT: Are there-are there statistics to support that?

MR. REIDHAAR: There is the testimony of Dr. Lowrey that each of the applicants admitted through the special admissions program has expressed an interest in serving the medically underserved areas.

WRIGHT: I realize it isn't in evidence, but my own experience has been

${ }^{240}$ Reply Brief of Appellant and Cross-Respondent, 291; reprinted in Slocum, ed., Bakke v. Regents, I: 285-308. The volume pagination is used, as the Brief itself is not paginated.

${ }^{241}$ Transcript of Oral Argument, 7-11; reprinted in Slocum, ed., Bakke v. Regents, II: $3-52$. Pagination from the volume is used, as the Transcript itself is not paginated.

${ }^{242}$ Transcript of Oral Argument, 11-12. 
members of minority races who have gone to law schools and medical schools do not as a whole tend to remain within the areas from which they came--they do just the reverse, they proceed to the suburbs just as the whites do. ${ }^{243}$

Having been challenged by Chief Justice Wright to produce some evidence, Reidhaar made the curious reply that "it should not in any sense be considered a loss that minority physicians practice in nonminority areas. "244 This was an odd thing for Reidhaar to say, as he conceded that his first defense of preferences was meaningless.

Reidhaar turned next to the "role model" defense of racial preferences, but was again challenged by Wright:

WRIGHT: I agree those are lofty ambitions, but is that really what we havewhat we have before us today? we have whether it is constitutional to use race as a classification for excluding students-that's what we really have, isn't it.

REIDHAAR: That certainly is a basic issue, Your Honor.

WRIGHT: It is the basic issue. ${ }^{245}$

Sticking to the basic issue, Chief Justice Wright went right to the heart of the

${ }^{243}$ Transcript of Oral Argument, 12-13; Chief Judge Wright's instincts have been confirmed by others. At Berkeley's law school, black graduates are slightly more likely than whites to pursue high-paying careers over public service; see Dinesh D'Souza, Illiberal Education: The Politics of Race and Sex on Campus (New York: Vintage, 1991), at 53-54; see also Richard Posner, "The DeFunis Case and the Constitutionality of Preferential Treatment of Racial Minorities," Supreme Court Review (1974): 17 (n. 34): "Those who argue that they will are careful to state the argument in an form that assures they will not be embarrassed by facts."

${ }^{244}$ Transcript of Oral Argument, 13.

${ }^{245}$ Transcript of Oral Argument, 14. 
matter: using race as a proxy for disadvantaged status. U.C. Davis was claiming that those specially admitted were economically or socially disadvantaged, but this was determined simply by inquiring into the applicant's race. The court seemed entirely willing to accept preferences for the poor and disadvantaged, but not simply because of race. This led to a rather startling exchange:

WRIGHT: Counsel, what you really did was to take the lazy man's way out. REIDHAAR: Pardon me, Your Honor?

WRIGHT: What you really did was just to simply take the lazy way out-just O.K., some certain percentage based on race and we make no other inquiry.

REIDHAAR: Well, I submit, Your Honor, the record shows that there was much-

WRIGHT: The alternative suggested by Mr. Colvin is a much more difficult standard to apply rather than just simply say based on race we take a certain percentage. That, I suggest, is the lazy way of doing it.

REIDHAAR: Your Honor, this is obviously a point upon which there can be differences of-

WRIGHT: Why, no, you don't have to do anything but just say race, period. . .. I still don't - and I asked the question earlier. I thought you said the breaking point was 2.5 and you admitted that students, minority students, who had 2.1 and - were admitted. . . . But under the special administration-special admission there is no standard, it could be $1.9,1.8$, is that correct? ${ }^{246}$

JUSTICE SULLIVAN: Well, you have two definitions of the word "qualified" then, do you not?

REIDHAAR: I don't believe that is so, Justice Sullivan. It's simply that-

${ }^{246}$ Earlier in the argument, Reidhaar conceded that Davis could conceivably take students with GPA's that low in order to fill the 16 spots; see Transcript of Oral Argument, 20-21. 
SULLIVAN: Don't you qualify a white student differently from a minority student? . . . Well you're just playing with the definition of "qualified." When you get over the one group your concept of qualified is different from qualified in the general admission group. ${ }^{247}$

The California Supreme Court rejected the Regents' argument. Over the lone dissent of Justice Torbiner, the court ruled 6-1 that Alan Bakke had been denied the equal protection of the laws. Justice Mosk, the legendary liberal of the court, wrote the opinion.

In the majority's opinion, it was "plain that the special admission program denies admission to some white applicants solely because of their race. "248 In their opinion, the Constitution required "strict scrutiny" here, and U.C. Davis' program failed that standard:

That whites suffer a grievous disadvantage by reason of their exclusion from the University on racial grounds is abundantly clear. The fact that they are not also invidiously discriminated against in the sense that a stigma is cast upon them because of their race, as is often the circumstance when the discriminatory conduct is directed against a minority, does not justify the conclusion that race is a suspect classification only if the consequences are detrimental to minorities.

Regardless of its historical origin, the equal protection clause by its literal terms applies to "any person," and its lofty purpose, to secure equality of treatment to all, is incompatible with the premise that some races may be afforded a higher degree of protection against unequal treatment than others. ${ }^{249}$

${ }^{247}$ Transcript of Oral Argument, 46-48.

${ }^{248} 18$ Cal. $3 \mathrm{~d}$ at 48.

${ }^{249} 18 \mathrm{Cal}$. 3d at 50-51. Justice Torbiner, in a lengthy dissent, insisted that Davis' program be upheld under the "rational basis" test, on the ground that "benign" racial classifications are not automatically suspect; see $18 \mathrm{Cal}$. 3d at 65-92. 
Unlike Judge Manker, Justice Mosk's opinion only mentioned Title VI in passing. That would have to wait until the Regents appealed to the Supreme Court of the United States.

\section{Regents of U.C. v. Bakke 250}

In their opening briefs to the court, both the Regents and Bakke's lawyers ignored Title VI in favor of a grander battle over the fourteenth amendment. ${ }^{251}$ This omission was not lost on members of the court, who pressed the issue at oral argument.

For oral arguments, the Regents retained Harvard's Archibald Cox, who was widely respected as a constitutional scholar and had gained notoriety as the Watergate prosecutor fired by Richard Nixon. When pressed by the court, Professor Cox repeatedly tried to avoid the issue, and argued that the California Supreme Court had not dealt with the issue, so it would be inappropriate to discuss it now. ${ }^{252}$

Reynold Colvin, who had been Bakke's lawyer throughout the case, finally took the hint. After arguing in circles for some time about the constitutional issues, Colvin finally realized that certain members of the court wanted the argument framed

${ }^{250} 438$ U.S. 265 (1978).

${ }^{251}$ See Brief for Respondent, in Slocum, ed., Bakke vs. Regents, V: 3-70; Reply Brief for Petitioner, in Slocum, ed., Bakke v. Regents, VI: 97-118.

${ }^{252}$ Transcript of Oral Argument, 11-13; reprinted in Phillip Kurland and Gerhard Casper, eds., Landmark Briefs and Arguments of the Supreme Court of the United States: 1974 Term Supplement (volume 100: Regents of the University of California v. Bakke, 1977) (Washington, D.C.: University Publications of America, 1978), 621-65. 
in terms of Title VI's explicit statutory prohibitions. ${ }^{253}$ Even so, Colvin's argument before the court was clumsy and ineffective..$^{254}$

The finai result in Bakke was a self-defeating mess. Justice Powell, writing for the court, produced a curious opinion: one block of four voted to invalidate U.C. Davis' program, while another block of four voted to uphold it in its entirety. Although Powell was the swing vote, he spoke for no one but himself.

It has long been a cannon of the court that it will not pass on constitutional issues if the case can be disposed of on statutory grounds. ${ }^{255}$ Since Title VI stood in the way of Justice Powell's idea of good policy, he had to dispose of this matter first.

Justice Powell began by conceding that Title VI is "majestic in its sweep:"

No person in the United States shall, on the ground of race, color, or national origin, be excluded from participation in, be denied the benefits of, or be subjected to discrimination under any program or activity receiving Federal

${ }^{253}$ Transcript of Oral Argument, 36-39.

${ }^{254}$ Before reaching its decision, the Court asked for supplemental briefs from both litigants regarding the applicability of Title VI; the case was not reargued on these grounds. See Supplemental Brief for Petitioner and Supplemental Brief for Respondent, in Slocum, ed., Bakke v. Regents, VI: 157-301.

${ }^{255}$ Ashwander v. TVA, 297 U.S. 288, 346 (1936) (Brandeis, J., concurring):

The Court will not pass upon a constitutional question although properly presented by the record, if there is also present some other ground upon which the case may be disposed of. This rule has found most varied application. Thus, if a case can be decided on either of two grounds, one involving a constitutional question, the other a question of statutory construction or general law, the Court will decide only the latter. 
financial assistance. ${ }^{256}$

It was clear beyond doubt that the University of California received millions in "financial assistance" from the federal government. Further, as Title VI states, no one person can be denied participation (in this case, admission) on the basis of race. As a matter of legal calculus in the highly competitive world of medical school admissions, the implications of racial preferences are obvious: setting aside certain seats for selected minorities prohibits anyone not of the selected group a chance to compete for those seats. As Dr. Lowrey stated in his deposition, U.C. Davis had 37 applicants for every opening, and competition was fierce. In the zero-sum game of admissions, every person given favored treatment meant one person was simultaneously kept out.

Considering how the court had dismantled Title VII in previous decisions, it is not at all surprising that Justice Powell decided to dismantle Title VI as an obstacle to its version of social justice. As Justice Powell saw Title VI, the key word was "discrimination." In his opinion, the meaning of "discrimination" was open to multiple interpretations. Powell relied on Justice Holmes' oft-repeated remark that "[a] word is not a crystal, transparent and unchanged, it is the skin of a living thought and may vary greatly in color and content according to the circumstances and the time in which it is used." 257

${ }^{256}$ United States Code 42: 2000(d); cited at 438 U.S. 284.

${ }^{257}$ Towne v. Eisner, 245 U.S. 418, 425 (1918); cited by Powell at 438 U.S. 284. 
The meaning of "discrimination" lay right at the heart of the $1964 \mathrm{Act}$, and changing its meaning would change the very scope of the Act. As Justice Black argued in a constitutional debate only a few years before the Bakke decision, this was of dubious legitimacy:

One of the most effective ways of diluting or expanding a constitutionally guaranteed right is to substitute for the crucial word or words of a constitutional guarantee another word or words, more or less flexible and more or less restricted in meaning. ${ }^{258}$

While Justice Powell could not erase the word "discrimination" and insert something else, the changing of this word's meaning had an identical effect. How he did this is illuminating.

Powell began by suggesting that "although isolated statements of various legislators, taken out of context, can be marshalled in support of the proposition that (Title VI) enacted a purely color-blind scheme . . . these comments must be read against the background of both the problem that Congress was addressing and the broader view of the statute that emerges from a full examination of the legislative debates. "259 Much like its perversion of Title VII in Weber, the court decided that the "animating spirit" could be found in the "broader view" of what Congress really intended. Like the Weber decision, the court had found a way to rewrite the 1964 Act to say what they thought it should say, rather than what it actually says.

\footnotetext{
${ }^{258}$ Griswold v. Connecticut, 381 U.S. 479, 509 (1965) (Black, J., concurring). ${ }^{259} 438$ U.S. at $284-85$.
} 
As Justice Powell saw the matter, Title VI was framed entirely in the context of discrimination against blacks, and that Congress never considered "hypothetical preferences" in their favor. ${ }^{260}$ Although Powell was correct in describing the main impetus of Title VI, it cannot seriously be argued that Congress was not aware of the call for racial preferences. As has been seen in the debates over the Philadelphia Plan, racial preferences were at the very heart of the debate. And while the debate centered largely around forced preferences, sponsors of Title VII insisted that voluntary preferences would be forbidden as well. Moreover, black leaders like Martin Luther King Jr. and others called for preferences as a form of compensatory or remedial justice, and these statements received wide attention. ${ }^{261}$

Powell's use of statutory history was no better. Powell argued that Title VI was essentially an extension of the Fourteenth Amendment, and incorporated the same constitutional principles. Since the Supreme Court has ruled on repeated occasions that the Constitution is not, in fact, color-blind, Title VI would not be color-blind either. For example, Powell began by reprinting a paragraph from Congressman Celler's speech to that effect: "It would, in short, assure the existing right to equal

${ }^{260} 438$ U.S. at 285.

${ }^{261}$ Graham, The Civil Rights Era, 100-121; Martin Luther King, Jr., Why We Can't Wait (New York: Harper \& Row, 1963), 146-51. 
treatment in the enjoyment of Federal funds. "262 Perhaps, in a vacuum, this citation might have some persuasive effect. However, it seerns fairly certain that Powell figured that no one would ever check his citations; as it was, Powell conveniently ignored the paragraph that immediately precedes the one he cited:

The bill would require that each Federal agency which extends financial assistance of the type covered by title VI must establish nondiscriminatory standards of general application. This means that it cannot apply one standard of conduct to one person and a different standard of conduct to another. ${ }^{263}$

Even more disturbing, Powell conveniently skipped Celler's statement from the previous page that:

This title simply provides that, where Federal money is used to support any program or activity-money which is paid into the Treasury by Negro and white citizens alike-the program must be used for the benefit of both races, without discrimination. This is basic American justice and fair play. ${ }^{264}$

This, however, was not Powell's most glaring error. On the next page after Powell cited Celler's speech, Powell noted that opponents of the Act protested repeatedly that the word "discrimination" was not defined in the Act. Powell read this as a deliberate omission, and concluded that the concept of "discrimination" was

${ }^{262}$ Congressional Record (31 January 1964) 110: 1519. Cited at 438 U.S. 286; emphasis is from Justice Powell's opinion. The entire quotation is not reprinted, as the remainder is of minor importance.

${ }^{263}$ Congressional Record (31 January 1964) 110: 1519 (remarks of Congressman Celler). The requirements Celler referred to involved the second part of Title VI, which requires federal agencies to create "rules, regulations, or orders of general applicability" that must be met before federal funds can be appropriated; see United States Code 42: 2000(d)-1.

${ }^{264}$ Congressional Record (31 January 1964) 110: 1518. 
left open for an expansive interpretation. At this point, Powell then added a citation from Senator Humphrey to bolster his claim. ${ }^{265}$

A sense of comical irony surrounds Justice Powell's reliance on Senator Humphrey's remarks, as it was none other than Humphrey who insisted repeatedly that the meaning of "discrimination" is both obvious and unchanging. Curiously, Justice Powell cited Humphrey's remarks on pages 5863-64 of the Congressional Record to bolster his rewriting of this crucial word; ${ }^{266}$ a review of these pages suggests that Justice Powell did not bother to read them:

The reason I asked for a discussion is that there is no foundation for saying that the word "discrimination" has no precise, legal meaning. The eminent retired Supreme Court Justice, Mr. Charles A. Whittaker . . . observes:

The meaning of the term "discrimination," in its legal sense, is not different from its dictionary meaning.

Webster's New International Dictionary defines discrimination as:

A distinction, as in treatment; esp., an unfair or injurious distinction. ... The Senator knows that the word "discrimination" has been used in many a court case. What it really means in the bill is a distinction in treatment. It means a distinction in treatment given to different individuals because of their different race, religion, or national origin. . . . I am sure he knows that a number of Federal statutes already on the books make it crystal clear that the word "discrimination" has been used repeatedly without any separate statutory definition, because the word "discrimination" is simply defined. It means

${ }^{265} 438$ U.S. at 287.

${ }^{266} 438$ U.S. at 287 (n. 24). 
"different treatment." That is all it means. ${ }^{267}$

Having thus ignored the actual text of Title VI, and reduced several thousand pages of legislative history to three pages of dubious analysis, Powell concluded that "in view of the clear legislative intent, Title VI must be held to proscribe only those racial classifications that would violate the Equal Protection Clause or the Fifth Amendment. "268 It was a performance worthy of Weber and Griggs.

As the obstacle of Title VI had thus been cleared, Powell then proceeded to

${ }^{267}$ Congressional Record (19 March 1964) 110: 5863-64; This argument was reiterated in the Bipartisan Civil Rights Newsletter No. 9:

Critics of the civil rights bill have charged that the word "discrimination" is left undefined in the bill and therefore the door is open for interpretation according to "whim or caprice." there is no mystery or vagueness about the word "discrimination". . . It means a distinction in treatment given to different individuals because of their different race, religion, or national origin. Congressional Record (9 April 1964) 110: 7477.

See also Congressional Record (3 June 1964) 110: 12,617 (remarks of Senator Muskie):

Discrimination in this bill means just what it means anywhere: a distinction in treatment given to different individuals because of their race, religion, or national origin. ... And, as a practical matter, we all know what constitutes racial discrimination.

See also Gold, "Griggs' Folly," at 565:

The Civil Rights Act contains no explicit definition of discrimination because everyone agreed that it meant what it had meant for many years.

${ }^{268} 438$ U.S. at 287. 
discuss the constitutional merits of the case. He began by conceding that medical school admissions is a zero-sum game, and people like Alan Bakke have legitimate grievances:

All state-imposed classifications that rearrange burdens and benefits on the basis of race are likely to be viewed with deep resentment by the individuals burdened. The denial to innocent persons of equal rights and opportunities may outrage those so deprived and therefore may be perceived as invidious. These individuals are likely to find little comfort in the notion that the deprivation they are asked to endure is merely the price of membership in the dominant majority and that its imposition is inspired by the supposedly benign purpose of aiding others. One should not lightly dismiss the inherent unfairness of, and the perception of mistreatment that accompanies, a system of allocating benefits and privileges on the basis of skin color, and ethnic origin. ${ }^{269}$

Having thus concluded that discrimination should not be lightly dismissed, Powell quickly offered a method to lightly dismiss discrimination.

Justice Powell insisted that "preferring members of any one group for no reason other than race or ethnic origin is discrimination for its own sake. This the Constitution forbids. "270 Powell then set forth a rationale for doing exactly what he claimed could not be done.

Powell's defence of racial preferences was based solely on the rubric of "diversity." As Powell saw the matter, U.C. Davis could legitimately want something more than a student body comprised entirely of whites and Asians. That is, black and hispanic students could bring "experiences, outlooks and ideas that

${ }^{269} 438$ U.S. at 294 (n. 34) (emphasis in original).

${ }^{270} 438$ U.S. at 307-8. 
enrich the training of its student body and better equip its graduates to render with understanding their vital service to humanity. "271

While Powell's argument has a superficial appeal, it is ultimately flawed. Powell's key failure was his inability to explain how blacks and hispanics brought any unique perspective to U.C. Davis, other than by virtue of their skin. Rather, Powell's argument suggests stereotyping of minorities by assuming that all blacks and hispanics grow up poor or disadvantaged, and see the world differently. This stereotyping has been criticized as racist. While certainly not as offensive as some crude "Sambo" caricature, Powell's "diversity" argument rests on the dubious proposition that blacks and hispanics have some inherent uniqueness by virtue of their race. As Stephen Carter, a Cromwell professor at Yale Law School (who happens to be black) argues, such arguments are inherently flawed:

Rather, the entire project of preferences by a claim that "broadcast diversity" can be enhanced by using skin color as a proxy for "certain" differing views; and a claim of that kind, no matter what fancy language is used to dress it up, does indeed rest on a racial stereotype . . . the experience of oppression is assumed to be sufficiently widespread that by knowing the gross difference of race (meaning color) we can know immediately a good deal more about the subtle differences what might properly be termed culture. ${ }^{272}$

Justice Brennan, realizing that Powell's majority opinion was rather flimsy in

${ }^{271} 438$ U.S. at 314.

${ }^{272}$ Stephen Carter, Reflections of an Affirmative Action Baby (New York: Basic Books, 1991), 39-40 (emphasis in original). Carter's reference to "broadcast diversity" referred to a case which Carter discussed in which the Supreme Court upheld the "diversity" argument in justifying preferences for minorities in the granting of broadcasting licenses. 
execution, wrote his own ambitious concurring opinion. In this concurrence, Brennan tried to find a more authoritative way to bulldoze Title VI and the Fourteenth Amendment and uphold U.C. Davis' program in its entirety.

Over the course of a good twenty-five pages, Justice Brennan tried his hand at law office history and Title VI. ${ }^{273}$ While conceding that Title VI might be read to require "strict racial neutrality," Brennan insisted that there are three "compelling" reasons for arguing that it does not. The first of his three "compelling" reasons is exactly one sentence long:

First, no decision of this Court has ever adopted the proposition that the Constitution must be colorblind. ${ }^{274}$

What this has to do with the interpretation of Title VI is not certain, though Brennan quickly tried to give it some relevance by immediately launching into his second "compelling" point:

Second, even if it could be argued in 1964 that the Constitution might conceivably require color blindness, Congress surely would not have chosen to codify such a view unless the Constitution clearly required it. ${ }^{275}$

Brennan's "compelling" point has the distinction of being every bit as uncompelling as his first. To begin with, Congress is free to codify any view it wants, so long as it respects constitutional limitations, and it is not the prerogative of

${ }^{273} 438$ U.S. at $328-55$.

274438 U.S. at 336.

${ }^{275} 438$ U.S. at 336. 
the court to decide what is or is not conceivable. Brennan's reading of Title VI also conveniently ignored other sections of the 1964 Act. For example, Title II banned discrimination in all private businesses that are open to the public, even though no such requirement is found in the Constitution. Title VII prohibited discriminatory hiring practices by private employers, though there is no constitutional requirement for such a prohibition, either.

Justice Brennan's third "compelling" point was part comical and part absurd:

Third, the legislative history shows that Congress specifically eschewed any static definition of discrimination in favor of broad language that could be shaped by experience, administrative necessity, and evolving judicial doctrine. ${ }^{276}$

Brennan felt that the explanation for this failure was an invitation for judicial discretion:

Specific definitions were undesirable, in the views of the legislation's principal backers, because Title VI's standard was that of the Constitution and one that could be administratively and judicially applied. . . . Indeed, there was a strong emphasis throughout Congress' consideration of Title VI on providing the Executive Branch with considerable flexibility in interpreting and applying the prohibition against racial discrimination. . . . Congress resolve not to incorporate a static definition of discrimination into Title VI is not surprising. ${ }^{277}$

As we have seen in the discussions over the Philadelphia Plan, everything Brennan said about the Act was flatly wrong. Opponents of the Act insisted ad nauseam that those charged with its administration would rewrite key provisions to

${ }^{276} 438$ U.S. at 337.

${ }^{277} 438$ U.S. at $338-39$. 
their liking, whereas supporters insisted to the point of exasperation that the words were so clear that they could not possibly be misinterpreted. ${ }^{278}$ Regardless, Brennan concluded that the words of Title VI were "cryptic," and the history of Title VI "unequivocally" supported his interpretation. ${ }^{279}$

Other peculiarities abound in Brennan's concurrence. At one point, Brennan cited Senator Humphrey's remarks on page 6553 to suggest that Title VI's standard was equal to the constitutional standard, and not anything more. ${ }^{280}$ This was presumably because of Humphrey's statement on page 6553 as follows:

As I have said, the bill has a simple purpose. That purpose is to give fellow citizens-Negroes-the same rights and opportunities that white people take for granted. This is no more than what was reached by the prophets, and by Christ himself. It is no more than what our Constitution guarantees. ${ }^{281}$

In a vacuum, Humphrey's statement might have some controlling weight. However, Humphrey was discussing Title VII, and not Title VI. Further, in the paragraph immediately proceeding the one above, Humphrey insisted that Title VII imposed

\footnotetext{
${ }^{278}$ See Kull, The Color-Blind Constitution, at 182-83; For a good example of this debate, see Senator Ervin discussing "discrimination" and enforcement regulations with Senator Javits; Congressional Record (18 March 1964) 110: 5606-67.

${ }^{279} 438$ U.S. at 340.

${ }^{280} 438$ U.S. at 338.

${ }^{281}$ Justice Brennan cited page 6553 , and referred only to the remarks of Senator Humphrey. However, a careful reading of page 6553 reveals nothing else on that page or on 6552 that would support Brennan's specific argument. This particular paragraph, aside from being the most plausible, is entirely consistent with other citations found in Brennan's opinion.
} 
strict racial neutrality:

It is claimed that the bill would require racial quotas for all hiring, when in fact it provides that race shall not be a basis for making personnel decisions. ${ }^{282}$

Another example of Brennan's mishandling of the evidence is found in his citation of Attorney General Robert Kennedy's testimony that "discrimination" had been defined differently in different contexts and federal programs. ${ }^{283}$ As has already been noted, Senator Humphrey insisted repeatedly that the word "discrimination" had an obvious, universal, and unambiguous meaning. It could be argued that Humphrey continued to make this point, in part, to assure that Kennedy's comments were not considered controlling, and that they would not be seized upon by opponents of the Act.

In conclusion, Brennan tried to tie Title VI to Title VII in the sense that Title VII does not prohibit voluntary racial preferences. ${ }^{284}$ As has been seen in the Weber case, this is simply a lie.

Justice Stevens, at the time the junior Justice of the court, wrote for the four dissenters. In his opinion, U.C. Davis' program flatly violated Title VI, and nothing further was needed to dispose of the case:

${ }^{282}$ Congressional Record (30 March 1964) 110: 6553.

${ }^{283} 438$ U.S. at 339.

${ }^{284} 438$ U.S. at 340 (n. 17); 367. 
The plain language of the statute therefore requires affirmance of the judgement below. A different result cannot be justified unless the language misstates the actual intent of the Congress that enacted the statute or the statute is not enforceable in a private action. Neither conclusion is warranted. ${ }^{285}$

While conceding that "reverse discrimination" and "affirmative action" were not directly debated in 1964 , Stevens noted that this omission did not affect the meaning of the words: "The genesis of the legislation, however, (does) not limit the breadth of the solution adopted." 286

Stevens also took exception to Powell and Brennan's argument that Title VI is nothing more than an extension of the Fourteenth Amendment. As Stevens argued, "Congress' expression of its policy to end racial discrimination may independently proscribe conduct that the Constitution does not. "287 Stevens also noted that in Lau v. Nichols the federal government insisted that "the applicability of Title VI does not depend upon the outcome of equal protection analysis ... [T]he statute independently proscribes the conduct challenged by petitioners and provides a discrete basis for injunctive relief." 288

During his analysis, Justice Stevens missed a key piece of evidence regarding the language of Title VI, though Bakke's lawyers did not. In their supplemental

${ }^{285} 438$ U.S. at $412-13$.

${ }^{286} 438$ U.S. at 413.

${ }^{287} 438$ U.S. at 417.

${ }^{288} 438$ U.S. at 417 (n. 20). Stevens noted that Justice Powell tried unpersuasively to distinguish Lau from Bakke's case. 
brief, they noted that Senator Case, a key proponent of the 1964 Act, had this to say about the language of Title VI:

(Title VI) is a statement of substantive right-a substantive right of individuals, of persons, not to be discriminated against or excluded from participation in or denied the benefits of any program or activity receiving Federal assistancemeans exactly what it says. ${ }^{289}$

Another interesting tidbit, missed or ignored in the Bakke opinions, comes from Senator Humphrey. In one of his lengthiest speeches regarding the scope of the Act, Humphrey discussed each title in turn. Regarding Title VI, Humphrey briefly noted that

Nothing in title VI precludes continued assistance to the American Indian who occupies a special status under our Constitution and the treaties which have been ratified pursuant to it. Nothing in title VI precludes special assistance to victims of a disaster or other events, such as particular classes of refugees, or specially underprivileged groups. ${ }^{290}$

Aside from the fact, already noted, that Congress knew how to protect voluntary preferences if it wanted to, this statement proves that Congress did not intend to prohibit preferences for "specially underprivileged groups." This goes back to the California Supreme Court, which seemed entirely willing to uphold preferences for poor or disadvantaged applicants, but was not at all amused when Bakke's lawyers proved that the program was really a subterfuge for racial preferences.

${ }^{289}$ Congressional Record (13 March 1964) 110: 5255 (emphasis added); cited in Supplemental Brief of Respondent Regarding Application of Title VI of the Civil Rights Act of 1963, 12. This Brief is reprinted in Slocum, ed., Bakke vs. Regents, VI: 157-97.

${ }^{290}$ Congressional Record (30 March 1964) 110: 6562 (emphasis added). 
And thus, we see that in Bakke Title VI has come full circle. A law written specifically to forbid the use of race in the admissions process and other programs has since been interpreted to specifically allow what it forbids. As the facts of Bakke have demonstrated, race has become the single most important criterion in the medical school admissions process. The applicant's race determines specifically what standard shall be applied to that applicant, and the file is weighted accordingly. As has been seen in other cases, the law was rewritten to preclude the possibility of supposedly unacceptable results. Even Harvard's Laurence Tribe, one of the nation's most liberal law professors and an outspoken defender of racial preferences, has conceded that "the apparent clarity of the language (of Title VI) poses a formidable obstacle not overcome by anything in the Bakke opinions upholding affirmative action. ${ }^{291}$

Perhaps the cruelest irony for Alan Bakke was U.C. Davis' insistence in its Bulletin that "religious preference and race are not considered in the evaluation of an applicant. ${ }^{292}$ For Alan Bakke, along with many others on the verge of admission,

${ }^{291}$ Laurence Tribe, Constitutional Choices (Cambridge: Harvard University Press, 1985), 233. Tribe's suggestion that the court should "overcome" the "apparent clarity" is revealing. Tribe's result-oriented approach to constitutional law has been sharply criticized as a means for the courts to write their own policy preferences into law, while still maintaining an air of legitimacy; see Robert Bork, The Tempting of America: The Political Seduction of the Law (New York: Touchstone, 1990), 199206. 3-69.

${ }^{292}$ Brief for Respondent, 10 (n. 7); reprinted in Slocum, ed., Bakke v. Regents, V: 
race was the overriding factor. ${ }^{293}$ But rather than proffer my own conclusions, the

Committee on Academic Nondiscrimination offers its own observations on Bakke and

affirmative action; I can do little to improve on their words:

It is the very insistence that innocent individuals sacrifice their hopes and plans, while powerful administrators shirk their own responsibilities, that, we submit, lends an especially galling quality to the high-minded sentiments with which the proponents of reverse discrimination characteristically try to justify it. "The most odious of all oppressions are those which mask as justice. "294

${ }^{293}$ While Bakke's case was being argued at the Supreme Court, Newsweek ran a story about Rita Clancey. Under the title "The Other Bakke," Newsweek noted that Clancey was an A-student at UCLA who put herself through school after growing up on welfare. Clearly, she came from a disadvantaged background. She was not admitted, but rather was first on the waiting list. She was conditionally admitted only after taking Davis to court. See "The Other Bakke," Newsweek, 24 October 1977, 46.

${ }^{294}$ Brief for the Committee on Academic Nondiscrimination and Integrity and the Mid-America Legal Foundation as Amicus Curiae, 16; reprinted in Slocum, ed., Bakke v. Regents, V: 541-651. The final sentence is a quotation from Krulewitch v. U.S. 336 U.S. 440, 458 (1949) (Jackson, J., concurring).

As stated in the Brief, this committee was formed in 1972 by professors nationwide who were "alarmed by the development of certain administrative and other practices . . . which they felt were in direct opposition to federal and state legislation relating to civil rights and to fair educational practices." Id., at 2. Although the composition of the committee does not increase its authority, its membership includes such luminaries as Daniel Boorstin, Eugene Rostow and Nathan Glazer. 


\section{CHAPTER 6}

\section{JOHNSON}

Howard W. (Judge) Smith was no friend of the 1964 Civil Rights Act. As a southern segregationist and chairman of the crucial House Rules committee, he used every bit of his considerable power to squash the Act. When proponents of the Act found a way to circumvent the Rules committee, Judge Smith was forced to play his trump card:

"Mr. Chairman," he drawled, "I offer an amendment."

The clerk read the paper that Smith had given him. "After the word 'religion,' insert 'sex' on pages $68,69,70$, and 71 of the bill."

The House erupted in shock as the full import of the amendment sank in. By adding the word "sex" to the list of discriminations (race, creed, color, and national origin) prohibited in employment, it would give all women-black and white-their first equal job rights with men. It would affect every employer, labor union, governmental body, and employment agency in the country. It would be one of the most radical civil rights amendments in U.S. history. . . .

It was a brilliant move by the arch foe of civil rights. Smith counted on the amendment passing and making H.R. 7152 so controversial that eventually it would be voted down either in the House or Senate. . . .

"Mr. Chairman," called Emanuel Celler loudly, "I rise in opposition to the amendment."

"Oh, no!" exclaimed the Judge, in mock horror. . . .

Suddenly there arose, in a spontaneous spirit of sisterhood, a bipartisan coalition of five congresswomen . . . to support Smith's amendment. ${ }^{295}$

Seizing the initiative, Congresswoman Katherine St. George quickly rose in defense of Judge Smith's intended Trojan Horse:

${ }^{295}$ Barbara and Charles Whalen, The Longest Debate, 115-17. 
I can assure you that we have fought our way a long way since those days of the Revolution. We have fought our way a long way even since the beginning of this century. Why should women be denied equality of opportunity? Why should women be denied equal pay for equal work? That is all we are asking.

We do not want special privileges. We do not need special privilege. We outlast you-we outlive you-we nag you to death. So why should we want special privileges?

I believe that we can hold our own. We are entitled to this little crumb of equality. 296

\section{Johnson v. Transportation Agency ${ }^{297}$}

Paul Johnson was a white male employee of the Santa Clara County

Transportation Agency. After seventeen years in private employ, he began working for the Agency in 1967. He worked as a road yard clerk and road maintenance worker. In 1979, an opening was announced for road dispatcher. It was a chance at promotion. Nine applicants filed for the position. Seven of the nine met the minimum score of 70 on an examination given by a two-member oral board. Johnson tied for second, with a score of 75 . Diane Joyce, the only female of the seven, was fourth with a score of 72.5 , which was rounded to 73 .

The Road Operations Division began its second round of evaluations, and used a departmental oral board to select one candidate from among the seven. The examiners unanimously concluded that Paul Johnson should receive the promotion to

${ }^{296}$ Congressional Record (8 February 1964) 110: 2581 (emphasis added); Judge Smith's proposed amendment and congressman Celler's reaction can be found on page 2577.

${ }^{297} 770$ F.2d 752 (9th cir. 1984). 
road dispatcher. In the meantime, Diane Joyce informed the County Women's Coordinator that she was available for promotion. The Women's Coordinator informed the Agency's affirmative action coordinator that Joyce was available. This information was in turn relayed to the Transportation Agency director. Diane Joyce was promptly promoted over Paul Johnson.

The federal district court reviewed the evidence and found that Johnson was, in fact, better qualified than Joyce, and was not promoted because of his sex. The Agency argued that Joyce was promoted in accordance with a voluntary, internallydeveloped affirmative action plan. This plan had been designed to rectify what the Agency's management felt was serious underrepresentation of women and minorities. The district court was not impressed, and ruled in favor of Paul Johnson's claims under Title VII. ${ }^{298}$ The ninth circuit court of appeals in San Francisco overturned the district court decision.

The court of appeals, in rejecting Johnson's claim, upheld the Agency's affirmative action plan. Much like the Philadelphia Plan, that plan did not set quotas for any job classifications. Rather, the Agency stated that its long-range "goal" was roughly proportional representation in all departments for women, minorities, and the handicapped. In this particular instance, no woman had ever held any of the 238

${ }^{298} 770$ F.2d at 753-54; the district court opinion was not published in any of the series of bound legal volumes. 
"skilled craft positions. "299

Relying heavily on the Weber decision, the court accepted the Agency's claim that the plan was designed to break "entrenched patterns of discrimination." 300 But going further than Weber, the court suggested that no prior finding of discriminatory practices would be necessary. In order to justify creation of such a plan, an employer would only need to demonstrate a "conspicuous imbalance" in its labor force. ${ }^{301}$ The district court found that there was, in fact, no prior history of discrimination by the Agency, nor any discrimination in its current promotion practices, but the court of appeals found this to be "irrelevant." ${ }^{132}$

The court seemed willing to accept statistics as proof of discrimination, since it concluded that "some forms of discrimination are so subtle or so accepted that they defy proof other than by statistics." Numbers would be allowed to replace proven discrimination. And thus, like previous cases interpreting Title VII, the intent requirement was thrown to the winds. The court of appeals even suggested in dictum that if Johnson had been hired, and Joyce was the plaintiff, the statistics would make

${ }^{299} 770$ F.2d at 754 . The skilled positions referred to in this case refer to road maintenance work. Although not clearly stated in the record, the implicit understanding is that employees in this department start by doing road repairs (i.e.: fixing potholes, etc), and work their way up to road crew supervisors.

300770 F.2d at 757.

${ }^{301} 770$ F.2d at 758.

302770 F.2d at 758 (n. 4). 
a "prima facie" case of discrimination! $!^{303}$

The opinion was not unanimous. Judge Wallace, in dissent, suggested that the case should have been remanded due to omissions in the district court record. Even so, he pointed out things that the majority opinion did not. Among other things, the Agency's director personally promoted Joyce. It was the only time he had directly promoted someone in the Roads Operation Division. Otherwise, the division would have promoted Johnson. Moreover, the record stated that Graebner, the Agency director, never bothered to scrutinize Joyce or Johnson's applications. He simply assumed that he had discretion to pick any candidate who was minimally qualified. ${ }^{304}$ Nonetheless, Wallace wanted the case remanded for further evaluation. Johnson appealed to the U.S. Supreme Court. He did not fare any better. Johnson v. Transportation Agency ${ }^{305}$

The Supreme Court, on appeal, upheld the court of appeals decision in its entirety. Justice Brennan, writing for the court, relied heavily on his own recent Weber opinion as a means of validating the Agency's plan. This was unremarkable, given Brennan's repeated endorsement of affirmative action. The opinions of the other judges are more revealing.

Justice Stevens, who wrote the dissent in Bakke and once ridiculed federal

${ }^{303} 770$ F. $2 \mathrm{~d}$ at 758.

${ }^{304} 770$ F.2d at $760-61$.

${ }^{305} 480$ U.S. 616 (1987). 
racial classifications by comparing them to Nazi citizenship laws, ${ }^{306}$ concurred with Justice Brennan's opinion. Stevens had come full circle. In his concurrence, Stevens strongly suggested that previous decisions interpreting Titles VI and VII were wrong. Even so, Stevens had reached the conclusion that decisions like Bakke and Weber were now settled parts of the law, and the "stability and orderly development of the law" would be better served by adherence to precedent. ${ }^{307}$.

Justice O'Connor concurred with Brennan for much the same reasons as Stevens. While stressing her commitment to stare decisis, O'Connor nonetheless referred to the court's current doctrine as "expansive and ill-defined." As O'Connor saw the matter, it would be a matter of "academic discussion" to speculate about returning to the original meaning of Title VII, because such speculation failed to deal with the "reality" of cases like Weber and others. ${ }^{308}$

Justice White, one of the five justices of the Weber majority, dissented in

${ }^{306}$ Fullilove v. Klutznick, 448 U.S. 448,534 (n. 5) (1980) (Stevens, J., dissenting):

Indeed, the very attempt to define with precision a beneficiary's qualifying racial characteristics is repugnant to our constitutional ideals . . . If the National Government is to make a serious effort to define racial classes by criteria that can be administered objectively, it must study precedents such as the First Regulation to the Reichs Citizenship Law of November 14, 1935 (offering various definitions of Jews).

${ }^{307} 480$ U.S. at 644; citing Runyon v. McCrary, 427 U.S. 160, 190 (Stevens, J., concurring).

${ }^{308} 480$ U.S. at $648-49$. 
Johnson. In a one paragraph dissent, Justice White stated that he would now vote to overrule Weber. ${ }^{309}$ This, however, was a side issue, as the real dissenting opinion belonged to Justice Scalia.

Scalia, joined by White and Chief Justice Rehnquist, wrote a lengthy and vehement dissent. ${ }^{310}$ Beginning with the observation that Title VII was written with "with a clarity which, had it not proven so unavailing, one might well recommend as a model cî statutory draftsmanship," Scalia argued that the majority had completed the process of "converting (Title VII) from a guarantee that race or sex will not be the basis for employment determinations, to a guarantee that it often will:

Ever so subtly, without even alluding to the last obstacles preserved by earlier opinions that we now push out of our path, we effectively replace the goal of a discrimination-free society with the quite incompatible goal of proportionate representation by race and by sex in the workplace. ${ }^{311}$

What makes Scalia's dissent so interesting is that he used the case before him to expound at some length about the political dynamics of affirmative action. Pouring through the record, he found that the concept of "voluntary" affirmative action was something of a stretch. For starters, department directors were required to explain why a woman or minority was not hired if there was "underrepresentation" in their

${ }^{309} 480$ U.S. at 657.

${ }^{310}$ Between Weber and Johnson, Chief Justice Burger had retired, and Justice Rehnquist was promoted by President Reagan to the Chief Justice's seat. Scalia was selected to take the associate justice's seat vacated by Rehnquist.

${ }^{311} 480$ U.S. at $657-58$. 
department. It was explained to directors that their own chances for advancement would be weighed against their record of hiring minorities. Such a record would need to be "statistically measurable." Perhaps most galling to Scalia, the record suggested that this was precisely what had occurred to Paul Johnson. When the Agency Director was asked if he had "any basis" for picking Joyce over Johnson, he replied "no, . . . As I've said, they both appeared, and my conversations with people tended to corroborate, that they were both capable of performing the work. "312

Scalia further challenged Brennan's heavy reliance on Weber. Aside from attacking that decision as wrong, Scalia noted that Weber was based at least partly on the idea that voluntary preferences would help to protect an employer from lawsuits under Griggs. Here, however, there was no history of discrimination which suggested that the employer was continuing discriminatory practices. ${ }^{313}$ The Transportation Agency simply decided that its work force should be balanced across the board. This was dangerously close to Griggs' prohibition against preferences for the sake of preferences. ${ }^{314}$ Even Bakke had rejected preferences for the sake of proportionality. 315

${ }^{312} 480$ U.S. at $659-63$.

${ }^{313} 480$ U.S. at $664-68$.

${ }^{314}$ Griggs v. Duke Power, 401 U.S. 424, 431 (1971): "Discriminatory preference for any group, minority or majority, is precisely and only what Congress has proscribed."

${ }^{315} 438$ U.S. at 307. 
In calling for the overruling of Weber, Scalia noted that the court's current affirmative action jurisprudence requires a "suspension of disbelief" about the concept of "voluntary" action. ${ }^{316}$ To Scalia, it was odd for a court that considered itself the defender of the defenseless to abandon Paul Johnson in the name of a judicially created fiction.

As Paul Johnson's case was effectively doomed by the Weber decision, the court felt no need to rehash the textual and historical arguments over Title VII again. Throughout the opinion, there were only scattered references to the Congressional Record, and those references were of minor consequence.

It was obvious that the "sex" provisions of the Act were added in an attempt to kill the bill. A review of the lengthy debate over the Act suggests that the "sex" provisions were virtually ignored by both supporters and opponents, and debate over Judge Smith's amendment lasted all of two hours. The "sex" provisions were generally ignored when the first regulations were announced. ${ }^{317}$

Nonetheless, the express language of Title VII, combined with the general hostility towards preferences and Congresswoman St. George's explicit rejection of special privileges, suggests that Title VII was meant to be gender-blind. The prohibitions against sex discrimination were meant to be identical to prohibitions
${ }^{316} 480$ U.S. at 673.
${ }^{317}$ Graham, The Civil Rights Era, 187. 
against race discrimination. That is, until Johnson proved them wrong. 


\section{CHAPTER 7}

\section{WARDS COVE}

From 1972 to 1974, a number of employees at the Wards Cove Packaging in Alaska company filed charges against the company with the EEOC. These employees charged that Wards Cove had discriminated against them by both disparate treatment and disparate impact models.

Wards Cove operates a number of salmon canning facilities in remote sections of Alaska. As the district court stated in its findings, the work is highly labor intensive, as the salmon must be canned immediately after being processed. Further, the salmon season varies yearly, and in some years there is no salmon run. When the run occurs, it is only for a short period of time, and the hours are very long. Employees are housed in facilities provided by the company. ${ }^{318}$ Although the opinion says little about the nature of the work, it seems obvious that working on a canning line is hard, punishing labor.

It would appear that the plaintiffs in Wards Cove were eager to exploit the Supreme Court's then-recent Griggs decision. Although there were scattered attempts to prove specific instances of discrimination, the plaintiffs tried to build the core of their case around widespread racial disparities in the company work force. Given that 26.

${ }^{318}$ Antonio v. Wards Cove Packaging Co., 34 E.P.D. para. 34,437 , pages $33,825-$ 
the Griggs decision had allowed statistical disparities as a surrogate for intentional discrimination, the plaintiffs in Wards Cove figured to use disparities to prove a violation of Title VII. ${ }^{319}$

Although there were a number of specific allegations, the core of the case was built around the disparities between permanent and seasonal employees at Wards Cove. The permanent, year-round employees were predominately white, whereas the seasonal employees, who worked on the cannery lines, were predominately Filipino and Alaskan Natives.

While the Griggs decision had the initial effect of rewriting the sections of Title VII that protected employment testing, the EEOC and civil rights lawyers quickly seized upon other parts of the decision. For example, Burger's majority opinion argued that "it was to achieve equality of employment opportunities and remove barriers that have operated in the past to favor an identifiable group of white employees over other employees. Under the Act, practices, procedures, or tests neutral on their face, and even neutral in terms of intent, cannot be maintained if they operate to 'freeze' the status quo of prior discriminatory employment practices. ${ }^{\text {" }} 20$

319 "Disparate treatment," in the context of employment and labor law, means employees being treated differently based upon a forbidden criteria (i.e. race, etc.); "disparate impact" refers to neutral hiring and promotion practices that produce disparities for certain groups or classes. See Barbara Schlei and Paul Grossman, Employment Discrimination Law, 2d ed. (Washington, D.C.: Bureau of National Affairs, 1983) at 13-22, 80-201.

${ }^{320}$ Griggs v. Duke Power, 401 U.S. 424, $429-30$ (1971). 
The conclusion that Frank Antonio and the other plaintiffs wanted the district court to draw was that the continuing racial disparities in the work force at Wards Cove essentially "froze" the status quo.

The district court found these claims unconvincing. For example, the plaintiffs alleged that Wards Cove had not posted announcements of available positions in higher-paying permanent jobs, and thus workers on the cannery lines were thus discouraged from applying for these positions. The court, however, found that "there has been a general lack of interest by cannery workers in applying for noncannery workers [sic] jobs." Further, the cannery worker positions offered no training for the permanent jobs, and people are rarely promoted from cannery to permanent positions. ${ }^{321}$ Thus, there would be little reason to announce positions to the temporary workers.

Other allegations were raised, but the district court rejected those as well. It was alleged that the predominantly Filipino composition of the work force was due to discriminatory practices, but Wards Cove argued that this was because of the racial composition of the union with which they had contracted. It was also alleged that whites were bunked in better quarters, but Wards Cove demonstrated that employees were assigned to bunkhouses by their jobs, and when they arrived. Those employees who worked the longest would be at the canneries when the winter came, and thus they were housed in the best facilities. The court folind no evidence of race being

${ }^{321} 34$ E.P.D. at 33,829 . 
used as a factor in the assignment of housing. ${ }^{322}$

The court was least impressed with the plaintiffs' statistical analysis, which was the backbone of their case. While the court conceded that, "considered collectively," the plaintiffs had raised a "marginal inference" of discrimination, the court noted how effectively the defendants had refuted the evidence. Among other things, the plaintiffs had used dubious counting methods, so that certain employees were recounted several times. The plaintiffs also alleged widespread nepotism in hiring for permanent jobs, but the defendants noted that much of this was caused by employees marrying one another after being hired. There were many white people with connections to employees who were not, in fact, hired, and the allegations of nepotism were unpersuasive. ${ }^{323}$

Having lost in the district court, the plaintiffs promptly appealed to the ninth circuit, which has jurisdiction over the western states. Normally, a case makes its way to the Supreme Court through a reasonably orderly process, with the trial, appeal, and then certiorari to the court. This progression was not applicable in Wards Cove, as the case was appealed and remanded several times over the course of fifteen years. Along with several procedural rulings, the ninth circuit produced three major opinions discussing this case in the context of Title VII and the applicability of Griggs.

32234 E.P.D. at $33,836$.

${ }^{323} 34$ E.P.D. at 33,843 . 
The ninth circuit initially upheld the district court opinion in its entirety. Writing for himself and Judges Choy and Tang, Judge Anderson reaffirmed the district court's skepticism about the Antonio's statistical analysis. Judge Anderson noted that the plaintiffs had not demonstrated discriminatory intent, and "desperately" needed statistical evidence to prove the effects of discrimination. Anderson referred to this as a classic case of putting the cart before the horse and noted that "this case clearly illustrates why courts and litigants must carefully examine proffered statistics to avoid the distortion of fact that they have the potential to produce." 324

The court noted that the plaintiffs relied heavily on Griggs, but the court rejected this emphasis specifically because the plaintiff's did not challenge any specific neutral hiring or promotion practice. The court rejected the "broad-scale attack" against "subjective employment practices" and insisted that these practices could not be read as illegal per se. ${ }^{325}$ The court also expressed its own skepticism about Griggs and disparate impact cases. The court noted that the disparate impact model was written by the Supreme Court and not Congress, and that Title VII was apparently designed to take race and gender out of the hiring process. The court expressed concern that the disparate impact model be used carefully, lest race or gender become the "overriding factor" and employers would be forced to hire by the

\footnotetext{
${ }^{324}$ Antonio v. Wards Cove Packing Co., 768 F.2d 1120, 1128 (9th cir. 1985).

${ }^{325} 768$ F.2d at $1131-32$.
} 
numbers to avoid litigation under Title VII. ${ }^{326}$

On appeal by the plaintiffs, the original appellate decision was withdrawn and returned to the ninth circuit for en banc review. This time around, the plaintiffs had more slaccess. The full court, while noting that its own precedents in this area had been somewhat contradictory, concluded that the district court had erred and the three-judge panel had also erred by affirming the original mistake.

The essence of the en banc opinion is the court's conclusion that the district court did not sufficiently respect the Griggs decision. Specifically, the district court did not force Wards Cove to meet the "business necessity" standard for a disparate impact challenge. That is, if a plaintiff proves that an employment practice has a discriminatory impact on minorities, the employer must do more than articulate a nondiscriminatory reason for using the practice. The employer must prove that the practice that created the disparate impact be job-related, essential, or have a business necessity or that no other selection practice is available that has a less discriminatory impact. ${ }^{327}$ This ruling was upheld in the final appeal before the case was sent to the Supreme Court. ${ }^{328}$

Wards Cove v. Antonio 329

${ }^{326} 768$ F.2d at 1132-33.

${ }^{327}$ Antonio v. Wards Cove Packing Co., 810 F.2d 1477, 1485-86 (9th cir. 1987).

${ }^{328}$ Antonio v. Wards Cove Packing Co., 827 F.2d 439 (9th cir. 1987).

${ }^{329} 490$ U.S. 642 (1989). 
Wards Cove appealed to the Supreme Court, but they did not stand alone.

Businesses on the whole were adamantly opposed to the "business necessity" doctrine. Whenever any practice was attacked as producing a statistical imbalance, an employer would be forced to prove that the practice was "essential" under this doctrine.

Employers could easily produce rational explanations for their employment and promotional criteria, but proving that such things were essential and irreplaceable was another matter. The Reagan Justice Department saw Wards Cove as a vehicle for challenging the Griggs rules. ${ }^{330}$

A badly divided Supreme Court ruled in favor of Wards Cove. Justice White, an original member of the Griggs court, wrote for himself, Rehnquist, Scalia, O'Connor and Kennedy. White's opinion marked a sharp departure from previous decisions interpreting Title VII.

White rejected the idea that employers could be sued for having nothing more than a racially imbalanced work force. As he explained it,

The Court of Appeals' theory, at the very least, would mean that any employer who had a segment of his work force that was--for some reason--racially imbalanced, could be haled [sic] into court and forced to engage in the expensive and time-consuming task of defending the "business necessity" of the methods used to select the other members of his work force. The only practicable option for many employers would be to adopt racial quotas, insuring that no portion of their work forces deviated in racial composition from the other portions thereof; this is a result that Congress

${ }^{330}$ David Savage, Turning Right: The Making of the Rehnquist Supreme Court

(New York: John Wiley \& Sons, 1992), 272-74. 
expressly rejected in drafting Title VII. ${ }^{331}$

As Justice White noted later in his opinion, the "essential" or "indispensable" business necessity standard "would be almost impossible for employers to meet. "332 White further rejected the idea that an imbalance in one section of a work force could be compared to an imbalance elsewhere at the same company, even though the jobs in the two sections might be somewhat fungible. ${ }^{333}$ And as a final matter, the court ruled that the ultimate burden of proving discrimination must always rest with the plaintiff. $^{334}$

Justice Stevens wrote for the four dissenters. His criticism of the majority was plain enough: the court was rewriting Griggs without admitting it. As Stevens pointed out, the Griggs opinion rejected the idea that an absence of discriminatory intent would protect an employment practice that produces racial disparities. Furthermore, Griggs specifically stated that in disparate impact cases, "the touchstone is business necessity," whereas the new ruling in Wards Cove stated that the "touchstone of this inquiry is a reasoned review of the employer's justification for his use of the challenged practice. ${ }^{.335}$ That is to say, an employer now need only

\footnotetext{
${ }^{331} 490$ U.S. at 652.

332490 U.S. at 659.

${ }^{333} 490$ U.S. at 653.

${ }^{334} 490$ U.S. at 660.

${ }^{335} 490$ U.S. at 671 .
} 
produce a reasonable justification for his practices. As Stevens suggested repeatedly, this casual approach to the abandonment of settled doctrine was not in the best interests of the legal system.

Lacking from White's majority opinion was any meaningful discussion of the legislative history surrounding Title VII. Had he reviewed the debates over Title VII and the shape Congress wanted Title VII litigation to take, he would have found much to support the final ruling in Wards Cove. White's opinion was a major revision of settled doctrine, and an appeal to congressional intent would have helped to deflect criticism that the opinion was an exercise in "judicial activism." 1366

Much of the legislative debate that is pertinent to White's opinion has been canvassed in the previous discussions of the Philadelphia Plan and Griggs. There is, however, something of importance that has not been discussed earlier, and that is the value of statistical analysis in Title VII cases. Title VII requires employers to maintain detailed records of their hiring practices. As has already been noted, critics of the Act insisted that federal regulators or civilian plaintiffs would use such statistics to challenge any employer who did not maintain a racially balanced work force. ${ }^{337}$

${ }^{336} 490$ U.S. at 663 (Stevens, J., dissenting).

${ }^{337}$ See e.g. Congressional Record (18 March 1964) 110: 5616: "Every time an employee of one race states that the employer does not have enough members of the other race working in the department or the room to which he is assigned, he can set the law in motion against the employer." (remarks of Senator Ervin). 
On its face, it would seem that the record-keeping requirements were designed to do just that, but the supporters of the Act insisted that this was not so. How they reconciled those requirements with the insistence that Title VII does not require racial balancing sheds considerable light on value of statistics in Title VII cases.

Senator Humphrey was the first to address the record-keeping requirements, and argued that they were "particularly essential in title VII because whether or not a certain action is discriminatory will turn on the motives of the respondent, which will usually be best evidenced by his pattern of conduct on similar occasions. "338 This seemed to suggest that a pattern of disparities could be used to infer discrimination, but the co-captains of Title VII quickly assured the Senate that this was not the case. In their seminal "Interpretive Memorandum of Title VII," Senators Clark and Case went straight to the heart of the matter:

There is no requirement in title VII that an employer maintain a racial balance in his work force ... It must be emphasized that discrimination is prohibited as to any individual. While the presence or absence of other members of the same minority groups in the work force may be a relevant factor in determining whether in a given case a decision to hire or to refuse to hire was based on race, color, etc., it is only one factor, and the question in each case would be whether that individical was discriminated against. ${ }^{339}$

This is entirely consistent with virtually everything else that was said by supporters of Title VII, and seems to suggest a plausible construction as well. While Title VII requires a specific finding of intentional discrimination, once that threshold

\footnotetext{
${ }^{338}$ Congressional Record (30 March 1964) 110: 6550.

${ }^{339}$ Congressional Record (8 April 1964) 110: 7213 (emphasis added).
} 
is past a "pattern or practice" of discrimination can be reasonably inferred from racial imbalances throughout the work force. The intent requirement would serve another purpose in keeping the federal judiciary from being overwhelmed by "pattern or practice" cases filed to challenge racial discrepancies. Such a construction would be entirely consistent with the Act's supporters repeated insistence that Title VII would not be used to force recalcitrant employers into hiring more minorities. It would also be entirely consistent with the House of Representative's original draft of Title VII:

Nothing in the act is intended to allow charges to be brought based upon disproportionate representation of members of any race, religion, color, national origin, or ancestry within any business enterprise or labor organization. General rules as to percentages, quotas, or other proportional representation shall not be the basis of charges brought under this act. However, disproportionate representation maybe considered as background evidence in an unlawful employment practice proceeding under this act. ${ }^{340}$

Unfortunately, Justice White ignored all this in his opinion. Even so, the Wards Cove opinion must be considered a huge improvement over the court's interpretation of Title VII in Griggs.

And thus, not with a bang but with a whimper the Supreme Court announced an entirely new approach to Title VII cases. This abrupt change of direction did not go unnoticed:

To live by the sword is to die by the sword. Business necessity was first smuggled into these cases by judicial legerdemain, and its demise (if such

${ }^{340}$ Congress, House of Representatives, Report No. 570, 88th Congress, 1st session, 5-6 (1963); as cited by Gold, "Griggs' Folly," at 526. 
there comes to be) proceeds, it appears, by the same dubious technique. There is no defensible construction of the 1964 act that yields the Griggs result. By the same token, there is no defensible construction of Griggs that supports its wholesale reinterpretation in Wards Cove. ${ }^{341}$

While the decision was praised by some, it was bitterly attacked by others as a reversal for civil rights litigants. Rather than praise the court for abandoning a flawed doctrine that ignored both text and legislative intent, key members of Congress quickly introduced legislation designed to overturn Wards Cove and other recent decisions. After an initial veto, the Civil Rights Act of 1991 was signed by President Bush. ${ }^{342}$ This in itself makes for an odd commentary regarding how thoroughly Title VII has been inverted by the federal courts, as the first major decision to correctly read Title VII was immediately denounced and overturned by Congress.

Such is the strange path that the federal judiciary has taken in reading Title VII.

\footnotetext{
${ }^{341}$ Richard Epstein, Forbidden Grounds: The Case Against Employment Discrimination Laws (Cambridge: Harvard University Press, 1992), 234.

${ }^{342}$ See Donald Nieman, Promises to Keep: African-Americans and the Constitutional Order, 1776 to the Present (New York: Oxford University Press, 1991), 223-27. Among other things, this Act reintroduced the business necessity requirement that the Court had just rejected, while also making it easier for plaintiffs to use statistics. While some suggested that these changes were necessary to return the 1964 Act to its original intent, it seems quite clear that these changes were necessary to return the 1964 Act to its interpretation by the federal judiciary prior to Wards Cove and other recent decisions.
} 


\section{CHAPTER 8}

\section{CONCLUSION}

After accusing the majority of using "intellectually dishonest means," Chief Justice Burger offered this observation from Justice Cardozo in his United Steelworkers $v$. Weber dissent:

The judge, even when he is free, is still not wholly free. He is not to innovate at pleasure. He is not a knight-errant, roaming at will in pursuit of his own ideal of beauty or of goodness. He is to draw his inspiration from consecrated principles. He is not to yield to spasmodic sentiment, to vague and unregulated benevolence. He is to exercise a discretion informed by tradition, methodized by analogy, disciplined by system, and subordinated to "the primordial necessity of order in the social life." Wide enough in all conscience is the field of discretion that remains. ${ }^{343}$

Such seems to be the case. Congress wroie the Civil Rights Act of 1964 with extraordinary precision; they also created a lengthy paper trail that only reinforces its literal reading. Those that voted for the Act did not have any choice. Critics in Congress insisted that the executive branch of the federal government would seize upon every ambiguity in an attempt to reinterpret the Act in a way that would circumvent its explicit language. Supporters insisted, in turn, that the language was so clear as to preclude the possibility of conflicting interpretations. As the decisions discussed in this thesis suggest, those opposed to the Act were only too accurate in

${ }^{343} 443$ U.S. at 218-19 (Burger, C.J., dissenting); quoting Benjamin Cardozo, The Nature of the Judicial Process, 141. 
making their predictions.

What is striking about all of this is the willingness of the federal judiciary to bestow legitimacy upon the illegitimate. The Constitution of the United States says that the President "shall take Care that the Laws be faithfully executed." This requirement extends to persons working throughout the executive branch, but as the behavior of the EEOC and other groups has demonstrated, this obligation is routinely flaunted in the name of "justice." In instances such as this, it is the responsibility of the Supreme Court to demand an end to such arrogant behavior. It has not done so. Its failure to act has seriously compromised its integrity.

The executive branch and the federal judiciary could never openly admit that they were rewriting the law. Instead, a resort was made to the "intent" of the law. That is, what Congress wrote was not exactly what it meant. As has been seen in these cases, the use of the Congressional Record in this matter makes for an excellent case study of law office history. Such "history" is expected from lawyers at the bench whose job it is to support an argument; its use by members of the bench is unforgivable. Historical analysis has the air of legitimacy, even when it is highly superficial and result-oriented, and can only be refuted by a more thorough analysis of the relevant materials. Given the volume of material in the Record, it is not at all surprising that so few have accepted the challenge, and have been willing to accept the "analysis" of others. 
Depending on who is asked, the question of racial justice in America is either an answered question, or a question incapable of being answered. What is certain is that the Congress that wrote the Civil Rights Act of 1964 answered this question on its on terms; as Congress writes the laws, it is the place of neither the judicial or executive branch to question their wisdorn. Furthermore, Congress answered this question in a way that was broadly acceptable to a large majority of Americans. Today, as this conclusion is being written, a passionate debate is forming about the future of racial and gender preferences in California. ${ }^{344}$ An initiative is slated for the 1996 elections that would eliminate all racial and gender preferences by the state or its agencies. Few seriously believe that this initiative to repeal affirmative action will fail. ${ }^{345}$ What has been missed in this debate is the fact that such an initiative should never have been necessary.

After the court had handed down its decision in Weber, Judge Gee published a rather startling statement in the Federal Reporter. Though he knew that he had no

${ }^{344}$ Steven Roberts, "Affirmative Action on the Edge," U.S. News \& World Report, February 13, 1995, 32; Joe Klein, "The End of Affirmative Action," Newsweek, February 13, 1995, 36; Richard Lacayo, "A New Push for Blind Justice," Time, February 20, 1995, 39; Jeffery Rosen, "Is Affirmative Action Doomed?", New Republic, October 17, 1994, 25.

${ }^{345}$ Professor Hugh Graham notes that racial preferences have been unpopular with the public as a whole. In 1977, those polled by Gallup opposed such preferences by eight to one; in 1988, opposition ran $79 \%$ to $15 \%$; see Graham, The Civil Rights Era, at 565 (n. 41-43). 
choice but to obey the orders of the Supreme Court, he wanted it known that he believed the court's decision was wrong. As Gee saw the matter, the court had placed justice above the law. While some may applaud the court for doing this, Gee noted that "justice" is essentially relative, while the law is not. His statement was respectful, but direct and to the point, and Gee's observations make a fitting conclusion to this thesis:

For myself only, and with all respect and deference, I here note my personal conviction that the decision of the Supreme Court in this case is profoundly wrong.

That it is wrong as a matter of statutory construction seems to me sufficiently demonstrated by the dissenting opinions of the Chief Justice and Mr. Justice Rehnquist. To these I can add nothing. They make plain beyond peradventure that the Civil Rights Act of 1964 passed the Congress on the express representation of its sponsors that it would not and could not be construed as the Court has now construed it. What could be plainer that the words of the late Senator Humphrey-defending the bill against the charge that it adumbrated quotas and preferential treatment-that "the title would prohibit preferential treatment for any particular group. . . ."? The Court now tells us that this is not so. That it feels it may properly do so seems to me a grievous thing. ... .

Though for the above reasons I think it is gravely mistaken, I do not say that the Court's decision is immoral or unjust-indeed, in some basic sense it may well represent true justice. . . .

Subordinate magistrates such as I must either obey the orders of higher authority or yield up their posts to those who will. I obey, since in my view the action required of me be the Court's mandate is only to follow a mistaken course and not an evil one. ${ }^{346}$

${ }^{346}$ United Steelworkers v. Weber, 611 F.2d 133 (5th cir. 1980) (Gee, J., dissenting; emphasis in original). 


\section{SELECTED BIBLIOGRAPHY}
A. Primary Sources

Bakke v. Regents of U.C. 18 Cal. 3d 34, 553 P. 2d 1152 (1976).

Congress. House of Representatives. Extended remarks of Congressman McLoskey. 88th Congress, 1st session Congressional Record (1964) volume 109.

Congress. . House of Representatives. Debate and proceedings regarding the Civil Rights Act of 1964. 88th Congress, 2nd session Congressional Record (1964) volume 110.

Congress. Senate. Debate and proceedings regarding the Civil Rights Act of 1964. 88th Congress, 2nd session Congressional Record (1964) volume 110.

Congress. Senate. Committee on the Judiciary. Civil Rights-The President's Program, 1963. 88th Congress, 1st session, 1963.

Contractors' Association v. Shultz 311 F. Supp. 1002 (E.D. Pa. 1970).

Contractors' Association v. Shultz 442 F.2d 159 (3d cir. 1971).

DeFunis v. Odegaard 82 Wash. 2d 11 (1973).

DeFunis v. Odegaard 416 U.S. 312 (1974).

Griggs v. Duke Power 292 F. Supp. 243 (M.D.N.C. 1968).

Griggs v. Duke Power 420 F.2d 1225 (4th cir. 1970).

Griggs v. Duke Power 401 U.S. 424 (1971).

Johnson v. Transportation Agency 770 F.2d 752 (9th cir. 1984).

Johnson v. Transportation Agency 480 U.S. 616 (1987).

Regenis of U.C. v. Bakke 438 U.S. 265 (1978). 
United Steelworkers v. Weber 443 U.S. 193 (1979).

Wards Cove v. Antonio 490 U.S. 642 (1989).

Weber v. Kaiser Aluminum 415 F. Supp. 761 (E.D. La. 1976).

Weber v. Kaiser Aluminum 563 F/2d 216 (5th cir. 1977).

B. Secondary Sources

Bickel, Alexander. The Morality of Consent. New Haven: Yale University Press, 1975.

Binion, Gayle. "'Intent' and Equal Protection: A Reconsideration." Supreme Court Review (1983): 397-457.

Blasi, Vincent. "Bakke as Precedent: Does Mr. Justice Powell Have a Theory?" California Law Review 67 (1979): 21-68.

Blumrosen, Alfred. "Strangers in Paradise: Griggs v. Duke Power Co. and the Concept of Employment Discrimination." Michigan Law Review 71 (1972): 59-110.

Bork, Robert. The Tempting of America: The Political Seduction of the Law. New York: Touchstone, 1990.

Brest, Paul. "Foreword: In Defense of the Antidiscrimination Principle." Harvard Law Review 90 (1976): 1-54.

Brody, Michael. "Congress, the President, and Federal Equal Employment Policymaking: A Problem in Separation of Powers." Bostoii University Law Review 60 (1980): 239-305.

Capaldi, Nicholas. Out of Order: Affirmative Action and the Crisis of Doctrinaire Liberalism. Buffalo, N.Y.: Prometheus Books, 1985.

Carter, Stephen. Reflections of an Affirmative Action Baby. New York: Basic Books, 1991. 47.

. "When Victims Happen to be Black." Yale Law Journal 97 (1988): 420- 
The Civil Rights Act of 1964: Text, Analysis, Legislative History. Washington, D.C.: Bureau of National Affairs, 1964.

Comment. "Disparate Impact and Subjective Employment Criteria under Title VII." Chicago Law Review 54 (1987): 957-79.

. "Enforcement of Fair Employment Under the Civil Rights Act of 1964." Chicago Law Review 32 (1965): 430-70.

. "Legal Standards and Statistical Proof in Title VII Litigation: In Search of a Coherent Disparate Impact Model." Pennsylvania Law Review 139 (1990): 455-503.

- "The Business Necessity Defense to Disparate-Impact Liability Under Title VII." Chicago Law Review 46 (1979): 911-34.

"Contracts-Labor Stipulations-Nondiscrimination-Affirmative Action Programs." Decisions of the Comptroller General 49 (1969): 59-71.

Cooper, George and Richard Sobol. "Seniority and Testing under Fair Employment Laws: A General Approach to Objective Criteria of Hiring and Promotion." Harvard Law Review 82 (1969): 1598-1679.

Currie, David. The Constitutivn in the Supreme Court: The Second Century, 18881986. Chicago: University of Chicago Press, 1990.

D'Souza, Dinesh. Illiberal Education: The Politics of Race and Sex on Campus. New York: Vintage, 1991.

Epstein, Richard. Forbidden Grounds: The Case Against Employment Discrimination Laws. Cambridge: Harvard University Press, 1992.

Glazer, Nathan. Affirmative Discrimination: Ethnic Inequality and Public Policy. New York: Basic Books, 1975.

Gold, Michael. "Griggs Folly: An Essay on the Theory, Problems, and Origin of the Adverse Impact Definition of Employment Discrimination and a Recommendation for Reform." Industrial Relations Law Journal 7 (1985): 429-598.

Gould, Robert. "Seniority and the Black Worker: Reflections on Quarles and its 
Implications." Texas Law Review 47 (1969): 1039-74.

Graham, Hugh. The Civil Rights Era: Origins and Development of National Policy. New York: Oxford University Press, 1990.

Gunther, Gerald. "Foreword: In Search of Evolving Doctrine on a Changing Court: A Model for a Newer Equal Protection." Harvard Law Review 86 (1972): 148.

Jones, James E. Jr. "The Bugaboo of Employment Quotas." Wisconsin Law Review (1970): 341-403.

Kaplan, John. "Equal Justice in an Unequal World: Equality for the Negro-The Problem of Special Treatment." Northwestern University Law Review 61 (1966): 363-410.

Karst, Kenneth. Belonging to America: Equal Citizenship and the Constitution. New Haven: Yale University Press, 1989.

Kelly, Alfred. "Clio and the Court: An Illicit Love Affair." Supreme Court Review (1965): 119-58.

Kheel, Theodore. Guide to Fair Employment Practices. Englewood Cliffs, N.J.: Prentice-Hall, 1964.

King, Martin Luther Jr. Why We Can't Wait. New York: Harper \& Row, 1963.

Kitch, Edmund. "The Return of Color-Consciousness to the Constitution: Weber, Dayton, and Columbus." Supreme Court Review (1979): 1-15.

Kull, Andrew. The Color-Blind Constitution. Cambridge: Harvard University Press, 1992.

Kurland, Phillip and Gerhard Casper, eds. Landmark Briefs and Arguments of the Supreme Court of the United States: Constitutional Law, 1974 Term Supplement. (Volume 80: DeFunis v. Odegaard, 1974) Arlington, V.A.: University Publications of America, 1975.

. Landmark Briefs and Arguments of the Supreme Court of the United States: Constitutional Law, 1977 Term Supplement. (Volumes 99-100: Proents of the University of California v. Bakke, 1977) Washington, D.C.: University 
Publications of America, 1978.

. Landmark Briefs and Arguments of the Supreme Court of the United States: Constitutional Law, 1978 Term Supplement. (Volume 112: United Steelworkers of America, AFL-CIO-CLC v. Weber, 1979) Washington, D.C.: University Publications of America, 1980.

Kurland, Phillip. "Ruminations on the Quality of Equality." Bringham Young University Law Review (1979): 1-23.

Law, Bureaucracy, and Politics: The Implementation of Title VI of the Civil Rights Act of 1964. Washington, D.C.: University Press of America, 1982.

Loevy, Robert. To End All Segregation: The Politics of the Passage of the Civil Rights Act of 1964. Lanham, M.D.: University Press of America, 1990.

Meltzer, Bernard. "The Weber Case: The Judicial Abrogation of the Antidiscrimination Standard in Employment." Chicago Law Review 47 (1980): 423-66.

Mitchell, John. "Legality of Revised Philadelphia Plan." Opinions of the Attorney General 42 (1969): 405-16.

Nash, Peter. "Affirmative Action under Executive Order 11,246." New York University Law Review 46 (1971): 225-61.

Nieman, Donald. Promises to Keep: African-Americans and the Constitutional Order, 1776 to the Present. New York: Oxford University Press, 1991.

Note. "Business Necessity under Title VII of the Civil Rights Act of 1964: A NoAlternative Approach." Yale Law Journal 84 (1974): 98-119.

- "Civil Rights-Employment Discrimination-Preferential Minority Treatment as an Appropriate Remedy Under Section 703(j) of Title VII." Tennessee Law Review 42 (1975): 397-405.

- "Developments in the Law: Employment Discrimination and Title VII of the Civil Rights Act of 1964." Harvard Law Review 84 (1971): 1109-1316.

. "Doing Good the Wrong Way: The Case for Delimiting Presidential Power Under Executive Order No. 11246." Vanderbilt Law Review 33 
(1980): 921-51.

. "Employment Discrimination-Weber v. Kaiser Aluminum \& Chemical Corp.: Does Title VII Limit Executive Order 11246?" North Carolina Law Review 57 (1979): 695-725.

. "Employment Testing: The Aftermath of Griggs $v$. Duke Power Company." Columbia Law Review 72 (1972): 900-25.

. "Executive Order 11,246 and Reverse Discrimination Challenges: Presidential Authority to Require Affirmative Action." New York University Law Review 54 (1979): 376-412.

- "Executive Order 11246: Anti-Discrimination Obligations in Government Contracts." New York University Law Review 44 (1969): 590-611.

- "Legal Implications of the Use of Standardized Ability Tests in Employment and Education." Columbia Law Review 68 (1968): 691-744.

. "Rethinking Weber: The Business Response to Affirmative Action." Harvard Law Review 102 (1989): 658-71.

. "Title VII, Seniority Discrimination, and the Incumbent Negro." Harvard Law Review 80 (1967): 1260-83.

Perry, Michael. "The Disproportionate Impact Theory of Racial Discrimination." Pennsylvania Law Review 125 (1977): 540-89.

Posner, Richard. "The DeFunis Case and the Constitutionality of Preferential Treatment of Racial Minorities." Supreme Court Review (1974): 1-32.

Robbins, Lance Jay. "Federal Remedies for Employment Discrimination in the Construction Industry." California Law Review 60 (1972): 1196-1234.

Rutherglen, George. "Disparate Impact under Title VII: An Objective Theory of Discrimination." Virginia Law Review 73 (1987): 1297-1345.

Sandalow, Terrance. "Racial Preferences in Higher Education: Political Responsibility and the Judicial Role." Chicago Law Review 42 (1975): 653703. 
Schlei, Barbara and Paul Grossman. Employment Discrimination Law 2d. ed. Washington, D.C.: Bureau of National Affairs, 1983.

Schwartz, Herman. "The 1986 and 1987 Affirmative Action Cases: It's All Over but the Shouting." Michigan Law Review 86 (1987): 524-76.

Schwerk, Robert. "The Philadelphia Plan: A Study in the Dynamics of Executive Power." Chicago Law Review 39 (1972): 723-60.

Sherain, Howard. "The Questionable Legality of Affirmative Action." Journal of Urban Law 51 (1973): 25-47.

Shoben, Elaine. "Probing the Discriminatory Effects of Employee Selection Procedures with Disparate Impact Analysis under Title VII." Texas Law Review 56 (1977): 1-45.

Slocum, Alfred, ed. Allan Bakke versus Regents of the University of California: Yolo County, California; Superior Court; California State Supreme Court. Dobbs Ferry, N.Y.: Oceana Publications, 1978.

Strauss, David. "The Myth of Colorblindness." Supreme Court Review (1986): 99134.

Symposium. "Regents of the University of California v. Bakke." California Law Review 67 (1979): 1-189.

Tribe, Laurence. Constitutional Choices. Cambridge: Harvard University Press, 1985.

Van Alstyne, William. "Rights of Passage: Race, the Supreme Court, and the Constitution." Chicago Law Review 46 (1979): 775-810.

Vaas, Francis. "Title VII: Legislative History." Boston College Industrial and Commercial Law Review 7 (1966): 431-58.

Whalen, Charles, and Barbara Whalen. The Longest Debate: A Legislative History of the 1964 Civil Rights Act. Cabin John, M.D.: Seven Locks Press, 1985.

Wilkinson, J. Harvie III. From Brown to Bakke: The Supreme Court and School Integration, 1954-1978. New York: Oxford University Press, 1981. 
Wilson, Hugh Steven. "A Second Look at Griggs v. Duke Power Company: Ruminations on Job Testing, Discrimination, and the Role of the Federal Courts." Virginia Law Review 68 (1972): 844-74.

Wright, J. Skelly. "Color-Blind Theories and Color-Conscious Remedies." Chicago Law Review 47 (1980): 213-45. 